\author{
Universidade de São Paulo \\ Faculdade de Medicina de Ribeirão Preto
}

\title{
ESTUDO COMPARATIVO DOS EFEITOS DA NEURÓLISE PRECOCE OU TARDIA DE PLEXOS SIMPÁTICOS NO TRATAMENTO DA DOR ONCOLÓGICA ABDOMINAL E PÉLVICA
}

\section{Raquel de Oliveira}

Tese apresentada à Faculdade de Medicina de Ribeirão Preto da Universidade de São Paulo para concorrer ao título de Doutor pelo curso de Pós-Graduação em Medicina Área de Concentração: Clínica Cirúrgica.

Ribeirão Preto - SP 


\author{
Universidade de São Paulo \\ Faculdade de Medicina de Ribeirão Preto
}

\title{
ESTUDO COMPARATIVO DOS EFEITOS DA NEURÓLISE PRECOCE OU TARDIA DE PLEXOS SIMPÁTICOS NO TRATAMENTO DA DOR ONCOLÓGICA ABDOMINAL E PÉLVICA
}

\section{Raquel de Oliveira}

Tese apresentada à Faculdade de Medicina de Ribeirão Preto da Universidade de São Paulo para concorrer ao Título de Doutor pelo curso de Pós-Graduação em Medicina - Área de Concentração: Clínica Cirúrgica.

Orientador: Prof $f^{\mathrm{a}}$. Dr ${ }^{\mathrm{a}}$. Marlene Paulino dos Reis.

Ribeirão Preto - SP 
Oliveira, Raquel.

Estudo comparativo dos efeitos da neurólise precoce ou tardia de plexos simpáticos no tratamento da dor oncológica abdominal e pélvica. / Raquel de Oliveira -Ribeirão Preto, 2004.

Tese de Doutorado -- Faculdade de Medicina de Ribeirão Preto

- Universidade de São Paulo, 2004.

Orientador: Prof ${ }^{a}$ Dr $^{a}$ Marlene Paulino dos Reis.

1.Dor oncológica. 2.Bloqueio neurolítico. 3.Plexo celíaco.

4.Plexo hipogástrico superior. 5. Cadeia Simpática Lombar. 
A minha orientadora, amiga e saudosa $\operatorname{Prof}^{\mathrm{a}} \operatorname{Dr}^{\mathrm{a}}$ Marlene Paulino dos Reis. Esta mineirinha, valente senhora, rigorosa e ávida em que acreditava, cheia de amor que suscitava impulsos altruístas de ternura a quem padecia de sofrimento. Dedicou-se inteiramente a estes seus impulsos e brilhou intensamente. Pessoa esta de minha mais alta estima e gratidão, a mim depositou a confiança de realizar este trabalho, um dos seus sonhos como dizia, agora realizado. Em sua memória, dedico-o. 
Aos meus pais, José Jomer e Sebastiana fonte de toda sabedoria, carinho, honestidade e perseverança, minha eterna gratidão e admiração.

Às minhas filhas, Clara e Cecília, pelo despertar do amor absoluto e tornaram-me uma pessoa mais completa e realizada.

Ao meu marido, Harnôldo, companheiro, amigo, por sua compreensão, paciência, incentivo sempre e incansável apoio ao longo de todos estes anos, dedico este com o mais puro amor. 


\section{AGRADECIMENTOS}

Ao Prof. Dr. Wiliam Alves do Prado por toda dedicação, orientação, apoio incondicional na elaboração e revisão deste trabalho. Seu estímulo à busca de mais conhecimentos, contribuição constante para meu crescimento científico e intelectual, fez-se este trabalho concretizado.

Aos docentes do Serviço de Anestesia e Dor do HCFMRP. Profs. Drs.: Gabriela Rocha Lauretti, Luis Vicente Garcia, Jyrson Guilherme Klamt e Anita Leocádia de Mattos pelo incentivo e apoio sempre em minha formação.

Aos ex-Residentes e a Equipe da Clínica de Tratamento da Dor pela contribuição na realização deste trabalho.

Aos funcionários do Centro Cirúrgico Ambulatorial e aos técnicos de radiologia do HCFMRP: Vera, Edina, Neusa, Edson, Adriana, Siane, Paulo, Liamar, Maribel, Alessandra, Auxiliadora, Tereza, Machado, Sílvio, Ângelo e Eliseu por serem sempre prestativos e atenciosos.

Às secretárias do serviço de Anestesia e Dor do HCFMRP: Sílvia, Luzia e Rita apoio e atenção sempre.

Aos amigos Profs. Marta Edna e Juan Stuardo Rocha pelo acolhimento, solicitude e afeto a mim e a minha família.

Aos amigos e "irmãos cearenses": Elodie, Roberto, Beatriz, Renan, Ana Paula, Mariana, Max, Paula, Cintya e João pela grande amizade, companheiros sempre, muita saudade!!!

Aos amigos Keny e Danielle Malta pelo carinho e amizade. Obrigada por compartilharem deste momento.

Às amigas Maria do Carmo, Simone, Claudia, Magda pelo apoio mesmo que distante. 
À todos os funcionários, médicos e enfermeiras do Centro Cirúrgico que contribuíram para a realização deste, obrigado.

À todos os pacientes participantes que me depositaram confiança e colaboraram neste trabalho tornando-o possível. 
“... quem não padece estas dores não as pode avaliar..."

M. Assis 


\section{RESUMO}

Oliveira, R. Estudo comparativo dos efeitos da neurólise precoce ou tardia de plexos simpáticos no tratamento da dor oncológica abdominal e pélvica. 2004. 127p. Tese (Doutorado) - Faculdade de Medicina de Ribeirão Preto, Universidade de São Paulo, Ribeirão Preto - SP.

Neurólises de plexos simpáticos têm sido utilizadas no tratamento da dor oncológica, mostrando ser um recurso terapêutico bastante eficaz e seguro. Alguns estudos apontam a utilização da neurólise de plexos simpáticos em estágios iniciais da doença por prevenir a dor e melhorar a qualidade de vida, contrariando a OMS que preconiza o uso de métodos invasivos em última instância. Em estudo prospectivo, randomizado e controlado, neurólise de plexos simpáticos realizada em estágios diferentes do tratamento da dor oncológica foi comparada com o tratamento farmacológico.

Foram selecionados 60 pacientes com câncer abdominal ou pélvico e alocados em três grupos. No grupo I (precoce) os pacientes estavam em uso de AINEs e opióides fracos ou fortes (dose inferior a 90mg/dia de morfina) e reportavam dor (VAS $\geq 4$ ) quando foram submetidos a neurólise plexo celíaco (NPC), neurólise do plexo hipogástrico superior (NPHS) ou neurólise plexo simpático lombar (NPSL) de acordo com o sítio de dor. No grupo II (tardio) a neurólise foi realizada quando a utilização de AINEs e morfina foram iguais ou superiores a $90 \mathrm{mg} / \mathrm{dia}$ de morfina e VAS $>4$. No grupo III (controle) os pacientes fizeram uso somente de medicação analgésica. Os pacientes foram observados durante 8 semanas e avaliados quanto à intensidade da dor (VAS), consumo de opióides e qualidade de vida.

Imediatamente após as neurólises e durante todo o tempo de observação, os pacientes dos grupos precoce e tardio apresentaram redução da intensidade da dor e do consumo de opióides, além disso melhora da qualidade de vida quando comparados com o grupo controle. Não houve diferenças entre os grupos precoce e tardio nestes aspectos. Efeitos adversos correlacionados com o uso de opióide, como náuseas e/ou vômitos, perda do apetite e constipação foram significativamente maiores no grupo controle. Complicações relacionadas às neurólises, tais como hipotensão e diarréia, foram transitórias e não deferiram significativamente do grupo controle. Não foram encontradas complicações sérias em nenhum dos grupos experimentais.

A neurólise de plexos simpáticos foi efetiva na redução da intensidade da dor e do consumo de analgésicos e dos efeitos adversos relacionados com a administração de drogas, e na melhora da qualidade de vida dos pacientes. Embora não havendo diferenças entre os grupos precoce e tardio, os resultados apontam a necessidade de utilizar esta técnica como recurso não somente em fase terminal da doença.

Palavras-chave: 1-Dor oncológica; 2-Bloqueio neurolítico; 3-Plexo Celíaco; 4-Plexo hipogástrico superior; 5-Cadeia Simpática Lombar. 


\begin{abstract}
Oliveira, R. The effects of early or late neurolytic sympathetic plexus block on the management of abdominal or pelvic cancer pain. 2004. 127p. Thesis (Doctoral) - Faculdade de Medicina de Ribeirão Preto, Universidade de São Paulo, Ribeirão Preto - SP.
\end{abstract}

Neurolytic sympathetic plexus blocks (NSPB) have been used as a quite effective and safe therapeutic resource for the treatment of cancer pain. Studies point to the use of NSPB in the early phases of the disease to prevent pain and to improve the life quality, contradicting WHO that extols the use of invasive methods ultimately. We compared the use of neurolytic plexus block in two different phases of the treatment of oncology pain with the pharmacological therapy.

In prospective study, randomized and controlled, sixty patients with abdominal or pelvic oncology pain were allocated to tree groups. In group I (early block) the patients using NSAID and weak opioid or oral morphine at a dose of less than $90 \mathrm{mg}$ /day and reporting pain (VAS $\geq 4$ ) were submitted to a neurolytic celiac plexus block (NCPB), superior hypogastric plexus block (SHPB) or lumbar sympathetic ganglionic chain (LSGCB), in accordance to the site of pain. In group 2 (late block) the patients were submitted neurolysis when using NSAID and oral morphine at a dose equals to or more than $90 \mathrm{mg} /$ day and VAS $\geq 4$. In group 3 (control), patients were treated with pharmacological therapy only. The patients were observed for 8 weeks and appraised for the intensity of the pain (VAS), opioid consumption and quality of live.

The patients of groups I and II had reduction of the intensity of the pain, opioid consumption and get better quality of live immediately after to the neurolytic and during the whole time of observation when compared with the group control. There were no significant differences between groups I and II with these aspects. Adverse effects correlated with the use of opioids, as nauseas and/or vomits, loss of the appetite and constipation were significantly larger in the group control. Neurolysis related complications such as hypotension and diarrhea, were transitory and statistically similar to these found in the control group. They were not found serious complications.

The neurolysis of sympathetic plexus was shown to be effective to reduce the intensity of pain, analgesic consumption and adverse effects related to the use of opioids, and in the improvement of the quality of life. The results point to the usefulness of indicating neurolytic procedure for the management of cancer pain not only in terminal phase of the disease.

Keywords: 1-Cancer pain; 2-Neurolytic block; 3-Celiac plexus; 4-Superior hypogastric plexus block; 5- Lumbar sympathetic ganglionic chain. 


\section{LISTA DE FIGURAS}

FIGURA 1- Média das idades nos grupos experimentais.............. 57

FIGURA 2- $\quad$ A variação da intensidade da dor (VAS) ................... 59

FIGURA 3- $\quad$ A variação do consumo de opióide......................... 60

FIGURA 4- $\quad$ O total dos escores do questionário de qualidade de 62

FIGURA 5- $\quad$ O total dos escores do fator somático..................... 63

FIGURA 6- $\quad$ O total dos escores do fator psicológico................... 64

FIGURA 7- $\quad$ O total dos escores do fator físico ........................ 65

FIGURA 8- $\quad$ O total dos escores do fator social...................... 66

FIGURA 9- Média das Pressões Arteriais Sistólica e Diastólica....... 68

FIGURA 10- Média da Freqüência Cardíaca........................ 69

FIGURA 11- Média dos escores do sintoma diarréia.................. 71

FIGURA 12- Média dos escores do sintoma perda do apetite.......... 72

FIGURA 13- Média dos escores do sintoma náuseas e vômitos....... 73

FIGURA 14- Média dos escores do sintoma constipação.............. 74 


\section{LISTA DE TABELAS}

TABELA 1- Aspectos demográficos dos grupos experimentais....... 56

TABELA A1- Aspectos gerais dos pacientes do Grupo I.............. 109

TABELA A2- $\quad$ Aspectos gerais dos pacientes do Grupo II.............. 110

TABELA A3- Aspectos gerais dos pacientes do Grupo III............. 111

TABELA A4- Comportamento das pressões arteriais e da freqüência cardíaca dos pacientes do Grupo I antes (inicial) e após (final) a neurólise do plexo simpáticos...................

TABELA A5- Comportamento das pressões arteriais e da freqüência cardíaca dos pacientes do Grupo II antes (inicial) e após (final) a neurólise do plexo simpáticos...............

TABELA A6- Relação dos pacientes excluídos conforme os critérios de saída do estudo nos grupos experimentais. 


\section{SUMÁRIO}

\section{RESUMO}

\section{ABSTRACT}

1. INTRODUÇÃO......................................................................... 2

1.1. Dor oncológica....................................................................... 2

1.2. Mecanismo da dor............................................................. 8

Mecanismos periféricos...................................................... 8

Nociceptores do aferente primário................................... 8

Nociceptores silentes.................................................. 10

Mediadores do aferente primário....................................... 10

Mecanismos espinhais..................................................... 11

Sensibilização central.................................................... 13

Vias nociceptivas ascendentes........................................... 14

Vias descendentes inibitórias.............................................. 15

1.3. Tipos de dor oncológica................................................... 16

1.4. Síndromes dolorosas no câncer............................................ 22

Dor aguda oncológica........................................................ 22

Dor crônica oncológica........................................................... 23

1.5. Tratamento da dor oncológica.............................................. 24

Técnicas analgésicas........................................................ 35

2. OBJETIVOS............................................................................. 43

3. MATERIAL E MÉTODOS ........................................................... 44

3.1. Casuística e Método............................................................... 44

3.2. Avaliação da dor.............................................................. 45

3.4. Avaliação do consumo de narcóticos......................................... 46

3.5. Avaliação da qualidade de vida................................................ 47

3.6. Seguimento dos pacientes..................................................... 49

3.7. Critérios de exclusão.......................................................... 49

3.8. Técnicas de bloqueio....................................................... 50

3.9. Análise estatística............................................................ 54 
RESULTADOS............................................................................ 55

4.1. Comentários gerais............................................................. 55

4.2. Aspectos demográficos................................................... 55

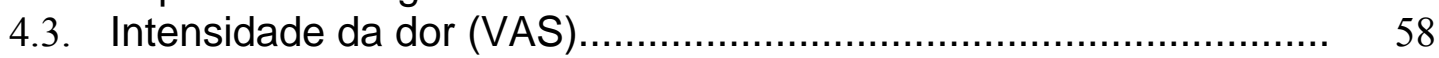

4.4. Consumo de narcóticos..................................................... 58

4.5. Qualidade de vida................................................................ 61

4.6. Efeitos colaterais e complicações................................................. 67

5. DISCUSSÃO.......................................................................... 75

6. CONCLUSÔES............................................................................. 87

REFERÊNCIAS BIBLIOGRÁFICAS........................................ 88

APÊNDICE 1 - Termo de consentimento................................. 101

APÊNDICE 2 - Questionário.................................................. 104

APÊNDICE 3 - Dados gerais dos pacientes.......................... 108 


\section{INTRODUÇÃO}

\subsection{Dor oncológica}

Incidência de novos casos de câncer no mundo está aumentando e estima-se que este número aproxima-se de nove milhões a cada ano (WHO, 1996). Nos Estados Unidos, são diagnosticados, anualmente, um milhão de indivíduos com câncer e a prevalência nesta população é de oito milhões (KIMBERLY et al., 1999). Na França são estimados 200.000 casos novos por ano (LARUE et al., 1995). O câncer, em adulto, é a causa de maior impacto em saúde pública nos Estados Unidos e a segunda maior causa de morte (WOLFF, 1997). No Brasil, as neoplasias são a segunda causa de óbito, só perdendo para as doenças do aparelho circulatório (BRASIL, 2001). Dor significativa está presente em cerca de dois terços dos casos de câncer, incluindo aproximadamente 25\% dos pacientes em tratamento ativo e em $90 \%$ naqueles com doença avançada. Até recentemente, 50 a $80 \%$ dos pacientes com câncer experimentavam algum tipo de dor devida à falha do tratamento paliativo (PATT; ISAACSON, 1996; PORTENOY; LESAGE, 1999).

A dor reportada pelos pacientes com doença maligna tem prevalência estimada de 5\% em leucemias, 20\% em linfomas, 40\% nos tumores gastrointestinais, 45\% em câncer de pulmão, 52\% em câncer de mama e 85\% em tumores ósseos primários. Um em cada cinco pacientes com câncer tem dor não controlada, mesmo dez anos após a introdução do programa de diretrizes da 
Organização Mundial da Saúde (OMS) para o controle da dor do câncer e sua "Escada analgésica de três degraus" (WHO, 1996).

Na dor do câncer existem múltiplos fatores causais e há um aumento substancial destes fatores com o avançar da doença (FOLEY, 1985). Pouco mais de 15\% dos pacientes com câncer não metastático têm dor. Mas um terço dos adultos e crianças com metástase reportam dor que interfere na atividade do paciente e requer o uso de analgésicos. Na doença avançada, 60 a 90\% dos portadores de câncer têm dor e postula-se que $25 \%$ deles morrem sem ter obtido alívio da dor severa. A prevalência e intensidade da dor oncológica variam dependendo do tipo de tumor, estágio da doença, presença e localização de metástases e adequações do tratamento da dor (FOLEY, 1985; LARUE et al., 1995; AHMEDZAI, 1997; PORTENOY; LESAGE, 1999).

A prevalência de dor crônica é de aproximadamente 30 a 50\% nos pacientes oncológicos que estão recebendo tratamento ativo para o tumor sólido e 70 a 90\% nos pacientes em estágio terminal (PORTENOY; LESAGE, 1999). A dor oncológica é freqüentemente tratada de modo inadequado, apesar de ser um grande, se não o maior temor e interesse da maioria dos pacientes oncológicos (PATT; ISAACSON, 1996; PORTENOY; LESAGE, 1999). Tratamento ineficaz da dor ainda tem sido documentado em inúmeras publicações, apesar dos esforços já realizados para reduzir a dor e suas conseqüências. Dor intensa está associada a distúrbios funcionais importantes como: distúrbio do sono, da atividade e do humor, perda do apetite, aumento da depressão e ansiedade, e piora na qualidade de vida (AHMEDZAI, 1997; CHAPMAN; GAVRIN, 1999; SARTI, 2001; COHEN et al., 2003). Larue et al. (1995) concluem que na França o tratamento da dor por câncer é 
inadequado e que $57 \%$ dos pacientes com câncer têm dor. Destes pacientes, 69\% têm dor intensa que impede a realização de suas atividades funcionais. Além disso, $30 \%$ dos pacientes não recebem medicação analgésica e 51\% não obtém alívio adequado da dor mesmo em uso de analgésicos. Cleeland et al. (1994) observaram que $67 \%$ dos pacientes oncológicos tinham dor, $36 \%$ deles tinham dor severa e incapacitante, e 42\% estavam recebendo tratamento inadequado para o alívio da dor. Também observaram que analgesia inadequada é três vezes mais provável em pacientes de classe sócio-econômica baixa. Em outro estudo realizado em Israel obteve-se que $77 \%$ dos pacientes ambulatoriais com câncer apresentavam dor e 81\% destes não tinham alívio adequado (SHVARTZMAN et al., 2003). Os autores apontam que apesar dos médicos estimarem níveis altos de dor, o impacto na qualidade de vida dos pacientes é subestimado.

Ahmedzai (1997) assegura que a dor gera um impacto no ambiente familiar ou nas pessoas que cuidam diretamente do paciente, interferindo, p.ex., na qualidade de sono, devido à interrupção do sono noturno pela dor ou pelo esquema da medicação. Os impactos psicológicos, financeiros e sociais são componentes existenciais na dor não controlada e, juntos, formam o conceito de "dor total". Este autor afirma ainda que a dor pode não ser causada propriamente pelo tumor, podendo ter outras causas como as produzidas por intervenções terapêuticas como a quimioterapia e radioterapia, por exemplo.

A OMS, em 1986, realizou consenso sistematizando o tratamento da dor oncológica, buscando intervenção racional da terapia farmacológica, de acordo com a efetividade e a magnitude da dor (WHO, 1996). O tratamento e as medicações administradas seguem uma hierarquia onde analgésicos não opióides 
são inicialmente utilizados até que o uso de opióides e/ou técnicas intervencionistas se tornem necessários. É a escada analgésica em três degraus para o alívio da dor preconizada pela OMS, em que o primeiro degrau corresponde à dor de baixa intensidade, o segundo à dor moderada e o terceiro à dor intensa. Os analgésicos orais opióides são o pilar da terapia e em cada degrau avança-se a potência do analgésico utilizado conforme a intensidade da dor do paciente, associando-se drogas adjuvantes, quando necessário. Esta escada busca implantar uma rotina simples, eficaz e barata para manipular a dor no paciente com câncer (JADAD; BROWMAN, 1995; WHO, 1996). Apesar do uso adequado destes princípios, 10 a $30 \%$ dos pacientes ainda mantêm quadro de dor. Nestes casos pode-se lançar mão de técnicas analgésicas para interromper as vias da dor, propondo-se, então, um quarto degrau para a escada analgésica (PATT et al., 1998; MIGUEL, 2000).

Com o progresso das investigações e melhor compreensão da dor relacionada ao câncer, surgiram organizações e sociedades para estudo do assunto. Em conseqüência, houve melhor controle da dor oncológica em $70-90 \%$ dos pacientes em alguns países (JACOX et al., 1994; ZECH et al., 1995). Mas a combinação de déficit de conhecimento das equipes médicas e os tabus culturais, no que tange ao uso dos opióides, ainda são os maiores fatores limitantes no tratamento da dor em pacientes com câncer (PATT; ISAACSON, 1996; RAAB, 2003; COHEN et al., 2003). A Academia Americana de Medicina da Dor (AAPM) publicou em 1999 os princípios éticos básicos para a prática da medicina da dor com diretrizes para assegurar um tratamento adequado e ético aos pacientes (AMERICAN ACADEMY OF PAIN MEDICINE, 1999). Em 1997, publicou definições de tolerância, dependência física e psicológica relacionadas ao uso de opióides para 
o tratamento da dor, visando diminuir os preconceitos na utilização destas substâncias (AMERICAN ACADEMY OF PAIN MEDICINE et al., 1997).

De acordo com as diretrizes da OMS, os opióides são drogas de primeira linha no controle da dor oncológica, mas seus efeitos colaterais e as altas doses necessárias para uma analgesia efetiva ainda constituem obstáculos. Existe receio de se utilizar doses elevadas em pacientes terminais que não obtiveram analgesia eficaz dado o risco de depressão respiratória. Outros efeitos adversos dos opióides, como constipação, náuseas, vômitos, sedação e confusão mental podem ser tratados com medicações específicas para cada sintoma. Porém, em doses elevadas, controlar os efeitos colaterais torna-se cada vez mais difícil (PARGEON; HAILEY, 1999; McQUAY, 1999). Os opióides causam tolerância, ou seja, é necessário o uso de doses maiores para atingir o mesmo efeito analgésico. A tolerância muitas vezes é confundida com dependência psicológica, sendo este um fenômeno complexo de fatores genéticos e biopsicossociais (GORDON, 2003).

Cherny e Portenoy (1999a) admitem que o sucesso do manejo da dor do câncer depende da habilidade do clínico em avaliar os problemas preexistentes, identificar e avaliar síndromes dolorosas e formular um plano compreensível no cuidado contínuo do paciente. Ventafridda (1989) foi mais longe impondo três maiores objetivos do tratamento da dor oncológica: primeiro, oferecer estratégia terapêutica que melhore e não atrapalhe a noite de sono do paciente; segundo, suavizar a dor em repouso; terceiro, o mais difícil, reduzir a dor produzida pelos movimentos, sem comprometer a performance física e cognitiva, aspecto importante em indivíduos que vivem sozinhos ou estão isolados. 
Yeager et al. (1995) demonstraram que a morfina deprime o sistema imunológico em voluntários sadios, enquanto Sacerdote et al. (2000) referem este efeito também na dor aguda pós-operatória em pacientes oncológicos. Isto se torna muito interessante, considerando o risco potencial de infecção em pacientes com câncer, os quais requerem controle da dor com opióides e que necessitam de cirurgia ou estão em uso crônico de doses altas de opióides para o manejo da dor. Então, faz-se necessária a maior compreensão dos mecanismos de dor e de novas técnicas para seu manejo.

\subsection{Mecanismos da dor}

Até 1960 , a dor era considerada como uma resposta sensorial inevitável a um dano tecidual. Havia pouco conhecimento da dor no campo da dimensão afetiva e comportamental, e nenhum conhecimento quanto à importância das diferenças genéticas, das experiências passadas, da ansiedade ou das expectativas. Recentemente, grandes avanços foram feitos para a compreensão dos mecanismos que envolvem a dor e tratamento de pessoas que sofrem com dor. A teoria do portão proposta em 1965 por Melzack e Wall enfatiza os mecanismos do sistema nervoso central que controlam a percepção dos estímulos nocivos, propondo um balanço entre os impulsos das fibras grossas A-beta (inibição) com as fibras finas A-delta e C (facilitação) na transmissão dos impulsos aferentes (1965 apud RAJ, 1996b). No entanto, esta teoria não explica as mudanças que ocorreram no sistema nervoso central ao longo do tempo em que persistem estímulos nocivos e os outros fatores externos que atingem o indivíduo como um todo. Atualmente, está 
amplamente aceito que a função dos nociceptores é alterada pela "sopa inflamatória" que caracteriza a região do tecido lesado. A lesão não produz apenas dor, mas pode também causar estresse, interferindo na homeostase do organismo. Este processo envolve atividade neural, hormonal e comportamental que derivam do determinante genético do indivíduo (LOESER; MELZACK, 1999).

\section{Mecanismos periféricos:}

Nociceptores do aferente primário

Os nociceptores são representados por terminais periféricos de fibras nervosas dos tipos $\mathrm{A} \delta$ e $\mathrm{C}$ de neurônios cujos corpos celulares se encontram no gânglio da raiz dorsal dos nervos espinhais ou nos gânglios sensoriais dos nervos cranianos V, VII, IX e X. Estes neurônios, chamados de neurônios aferentes primários, são células pseudo-unipolares que, além do ramo periférico, possuem um ramo central que adentra o corno dorsal da medula espinhal pela raiz dorsal. As fibras do neurônio aferente primário variam quanto ao grau de mielinização e à velocidade de condução de estímulos. Na periferia, os nociceptores são classificados em mecanonociceptores, ativados apenas por estímulos mecânicos intensos, nociceptores polimodais, que respondem a qualquer tipo de estímulo nocivo, nociceptores mecanotérmicos, que respondem tanto a estímulos térmicos moderados quanto a estímulos mecânicos intensos, e nociceptores para o frio, que são ativados por estímulos de baixa temperatura (PRADO, 1999). 
A dor percebida em indivíduos normais é conseqüência da ativação de neurônios sensoriais altamente especializados, denominadas células de alto limiar ou nociceptivas específicas. Os terminais periféricos destes neurônios sensitivos são adaptados para somente serem ativados por estímulos intensos ou potencialmente lesivos. Estas fibras são funcionalmente distintas das fibras sensoriais de baixo limiar as quais normalmente só geram sensações em resposta a estímulos não lesivos ou de baixa intensidade (WOOLF; DECOSTERD, 1999).

O dano tecidual causado por traumas ou inflamação produz a liberação de substâncias químicas endógenas, chamadas algogênicas, algésicas ou produtoras da dor para o fluido extracelular, envolvendo os nociceptores. Estas substâncias são oriundas do dano tecidual e de células inflamatórias como os macrófagos, linfócitos e mastócitos (RAJ, 1996a; SIDDALL; COUSINS, 1998).

As estruturas somáticas como os músculos, articulações, tendões e outras estruturas profundas são supridas por fibras C e provavelmente também por fibras A-delta. As vísceras são supridas por fibras aferentes primárias do tipo C, e algumas fibras aferentes A-delta, as quais são ativadas por inflamações, contrações sob condições isométricas, isquemia, distensão rápida, e outros estímulos nociceptivos. Estes nociceptores, ativados por estímulos nocivos ou por substâncias algogênicas endógenas, transduzem o estímulo dos impulsos nociceptivos que são conduzidos ao corno dorsal da medula espinhal. A quantidade de estímulos nos aferentes nociceptivos é influenciada não apenas pela intensidade e duração da estimulação, mas também pelo micro-ambiente dos nociceptores e outros fatores (RAJ, 1996a). 


\section{Nociceptores silentes}

Após a sensibilização, muitos nociceptores que normalmente não seriam ativados, tornam-se excitáveis. Estes nociceptores que são ativados somente sob condições patológicas como na inflamação, são chamados de nociceptores silentes ou adormecidos, descritos primeiramente por Schaible e Grubb (1993) no tecido articular, e posteriormente demonstrados também em tecido viscerais e cutâneos.

\section{Mediadores do aferente primário}

Farmacologicamente, várias substâncias químicas (glutamato, bradicinina, prostaglandinas, serotonina, histamina, potássio, substância $P$, óxido nítrico) de origem vascular (plaquetas, neutrófilos, linfócitos, e macrófagos) e também de mastócitos, são liberadas para dentro do tecido lesado. Muitos peptídeos estão contidos nas fibras aferentes primárias e podem ser alterados por estímulos mantidos ou por dano neural. O modo como algumas destas substâncias atuam ainda não está claro, mas outras como a substância $P$, já estão bem estabelecidas. A substância $P$ causa a degranulação de mastócitos e conseqüente liberação de histamina, provocando vasodilatação e extravasamento plasmático, com a subseqüente liberação de outros algógenos (bradicinina, serotonina) e ativação de células inflamatórias (macrófagos, monócitos, e linfócitos). Além disso, a substância P ativa a produção de óxido nítrico, vasodilatador originário do endotélio das paredes dos vasos sangüíneos. Outros fatores, como as citocininas (interleucinas, interferons e fator de necrose tumoral), são liberadas de células fagocitárias e de células do sistema imune e tem importante ação no processo inflamatório. O fator de crescimento de nervo (NGF) tem importante papel no desenvolvimento de neurônios 
sensoriais e autonômicos, e também no processo da nocicepção. Este fator está aumentado nos processos inflamatórios e causa o aumento da excitabilidade dos nociceptores contribuindo para a instalação de hiperalgesia, ou seja, sensibilidade exagerada a um estímulo doloroso (BESSON, 1999).

Como parte da resposta inflamatória à lesão tecidual, tem-se inicialmente a hiperalgesia primária. Quando há expansão gradual para as áreas vizinhas ao tecido inflamado, tem-se a chamada hiperalgesia secundária. Este quadro de hiperexcitabilidade e extensão do campo receptivo é acompanhado por expansão da área medular que recebe informações nociceptivas da periferia (PRADO, 1999).

\section{Mecanismos espinhais:}

O corno dorsal da medula espinhal é o local das terminações centrais dos aferentes primários. Nele há complexa interação entre o aferente primário, neurônios espinhais intrínsecos e terminações nervosas de fibras descendentes oriundas do cérebro. Os braços periféricos dos neurônios primários (fibras A-delta e C) terminam nas lâminas I, II e $\mathrm{V}$ do corno dorsal da medula espinhal, onde fazem sinapses com várias classes de neurônios de segunda ordem. Algumas destas fibras ascendem ou descendem alguns segmentos do trato de Lissauer antes de efetuar sinapses com células espinhais (SIDDALL; COUSINS, 1998; WOOLF; DECOSTERD, 1999).

Existem duas classes de neurônios de segunda ordem associados com o processo sensorial no corno dorsal da medula. A primeira classe é a dos neurônios nociceptivos específicos ou de alto limiar, que estão presentes nas 
lâminas I e II e respondem apenas a estímulos nociceptivos de alta intensidade. A segunda classe é a dos neurônios de faixa dinâmica ampla (WDR), também chamados células polimodais ou multirreceptivas, que estão presentes na lâmina $\vee$ e respondem tanto a estímulos nocivos, de variada intensidade, quanto a estímulos tácteis ou de pressão (REGAN; PENG, 2000).

Como na periferia, no corno dorsal da medula existe enorme quantidade de neurotransmissores e receptores: vários peptídeos (substância P, peptídeo relacionado com gene da calcitonina, somatostatina, neuropeptídeo $\mathrm{Y}$, e galanina), aminoácidos excitatórios (ácido gama aminobutírico [GABA], e glicina), óxido nítrico, metabólitos do ácido aracdônico, opióides endógenos, adenosina, e monoaminas (serotonina e noradrenalina). Esta lista aponta para diversas possibilidades terapêuticas para o controle farmacológico da transmissão das informações dos nociceptores para o cérebro (BESSON, 1999).

Os principais neurotransmissores da informação dolorosa no corno dorsal da medula são a substância $P$, glutamato e neurocinina $A$, que podem ser liberados simultaneamente por estímulos nociceptivos (REGAN; PENG, 2000). O glutamato e o aspartato são aminoácidos excitatórios encontrados em grande quantidade nas células do corno dorsal da medula. O aferente primário contém mais de um neurotransmissor armazenado em vesículas no interior de seus terminais. A substância P facilita a resposta das células ativadas pelos estímulos cutâneos nocivos. Outros neurotransmissores como a colecistocinina, e o peptídeo vasoativo (VIP), parecem ser menos seletivos. Eles produzem efeitos excitatórios e facilitatórios nos neurônios que respondem a uma ampla variedade de estímulos (RAJ, 1996a). 
O receptor para glutamato tipo NMDA (N-metil-D-aspartato) é importante nos eventos sinápticos que produzem à sensibilização central e hiperalgesia. A liberação de substância $P$, durante a estimulação aferente repetitiva, remove o bloqueio de íons de magnésio do receptor NMDA, permitindo que o glutamato ative o receptor NMDA, e assim, a entrada de cálcio para dentro dos neurônios. Este processo gera hipersensibilização medular e amplificação dos impulsos periféricos. A entrada de cálcio pode levar à ativação de fosfolipase e a produção de prostanóides para a medula, um efeito que pode ser a base para a ação central dos antiinflamatórios não esteroidais -AINEs (BESSON, 1999).

\section{Sensibilização central}

Em adição às mudanças ocorridas no neurônio periférico em decorrência de hipersensibilidade dolorosa devida a dano tecidual, ocorrem mudanças na excitabilidade dos neurônios medulares, conhecida como sensibilização central (WOOLF; DECOSTERD, 1999). Estes autores descrevem que a sensibilização central é o maior contribuidor para a inflamação e a dor neuropática produzindo hiperalgesia secundária e alodínia tátil. Após a indução da plasticidade no corno dorsal ocasionada pelo estímulo nociceptivo, ocorre aumento da excitabilidade da membrana neuronal, em decorrência da liberação de aminoácidos e neuropeptídeos excitatórios nos terminais das fibras C, que atuam em receptores iônicos e metabotrópicos pós-sinápticos para produzir corrente iônica e ativação de sinais da cascata de transdução no neurônio. 


\section{Vias nociceptivas ascendentes:}

Raj (1996a) descreve que após sofrerem modulação no corno dorsal, os impulsos nociceptivos passam para os neurônios de segunda ordem, cujos axônios cruzam anterior e contralateralmente ao lado de entrada do aferente primário no corno anterior da medula. Outros axônios de neurônios de segunda ordem passam para o fascículo ventrolateral ipsilateral. Alguns neurônios anterolaterais provocam respostas reflexas autonômicas segmentares. O conjunto destas fibras dirigem-se diretamente ao tálamo ou fazem sinapses em estruturas intermediárias convergindo para o córtex, compondo os tratos ascendentes.

São compostos por dois sistemas ascendentes: um que trafega medialmente pelo tronco cerebral, contendo tratos filogeneticamente mais antigos e denominados paleoespinotalâmico, espinorreticular, espinomesencefálico e proprioespinhal, e outro que mantém curso lateral pelo tronco cerebral e conduz rapidamente a dor, contendo os tratos neoespinotalâmico, espinocervical e dos núcleos da coluna dorsal (PRADO, 1999).

O sistema medial transmite nocicepção do corpo e da cabeça. Por ser composto por fibras finas, de natureza multisináptica e pouca organização somatotópica, os impulsos que chegam ao córtex são mais lentos que os que trafegam pelo sistema lateral, a dor percebida é mal localizada, porém de forte conotação afetiva, motivando reações comportamentais defensivas. Neurônios deste sistema projetam seus axônios para núcleos da formação reticular na medula, ponte, mesencéfalo, matéria cinzenta periaquedutal, hipotálamo e núcleos medial e intralaminar do tálamo. Já o sistema lateral presta-se à rápida condução da informação nociceptiva, permitindo rápida percepção e localização da origem da dor, 
além de informações sobre o início da lesão, da intensidade e duração do estímulo, podendo rapidamente gerar uma resposta que previna um futuro dano tecidual. As fibras deste sistema dirigem-se ao tálamo ventral póstero-lateral e porção medial do tálamo posterior. No tálamo estas fibras fazem sinapse com neurônios que se projetam ao córtex somatossensorial, o qual tem estreita relação topográfica com a região estimulada (RAJ, 1996a; PRADO, 1999). Os tratos espinorreticular e espinomesencefálico participam de mecanismos de informação da dor, mas estão envolvidos principalmente com respostas reflexas autonômicas e componentes motivacionais e afetivos da experiência dolorosa (PRADO, 1999).

\section{Vias descendentes inibitórias:}

As vias descendentes provêm de estruturas supra-espinhais como hipotálamo, matéria cinzenta periaquedutal, locus coeruleus, núcleo magno da rafe, e alguns núcleos reticulares (SIDDALL; COUSINS, 1998).

A serotonina e a noradrenalina participam como mediadores de vias descendentes de controle da nocicepção. As fibras descendentes serotonérgicas ativam neurônios encefalinérgicos, que, por sua vez, liberam opióides endógenos que inibem a passagem de impulsos nociceptivos do aferente primário para a célula de segunda ordem. A noradrenalina liberada por terminais adrenérgicos pode inibir a passagem de impulsos nociceptivos por atuar diretamente sobre células de segunda ordem ou, indiretamente, estimulando neurônios colinérgicos intrínsecos da medula espinhal. A utilidade clínica dos antidepressivos (p.ex., amitriptilina) no controle da dor neuropática tem sido imputada à propriedade que algumas destas substâncias possuem de inibir a recaptação de serotonina e noradrenalina, potencializando o efeito da ativação das vias descendentes inibitórias da nocicepção (PRADO, 1999). 


\subsection{Tipos de dor oncológica}

A Associação Internacional para o estudo da dor (IASP) definiu a dor como sendo experiência sensorial e emocional associada a dano tecidual, potencial ou de fato, ou ainda, descrita em termos que sugerem tal dano (COUSINS; SIDDALL, 1998).

A dor pode ser classificada em aguda e crônica. A dor aguda é definida como aquela que surge após um estímulo lesivo e tem a função de alertar o indivíduo e, assim, diminuir o dano. A lesão tecidual altera a resposta característica dos nociceptores, suas conexões centrais e, na região da lesão, de terminais nervosos autonômicos. É autolimitada e cura-se com o desaparecimento do processo lesivo. Este tipo de dor é visto em pacientes após trauma, intervenções cirúrgicas e outras condições (LOESER; MELZACK, 1999).

A dor crônica, como a da lombalgia, da neuralgia pós herpética ou da fibromialgia, é comumente iniciada por um dano tecidual ou doença, mas que pode se perpetuar por outros fatores que causam a dor. A lesão pode exceder a capacidade do organismo para se curar, devido à perda de uma parte do corpo, à excessiva extensão do trauma e subseqüente sequela, ou ao envolvimento do sistema nervoso na própria região da lesão (LOESER; MELZACK, 1999). A dor crônica difere substancialmente da dor aguda em termos de persistência e mudanças adaptativas tais como a neuroplasticidade que tem sido descrita em vários níveis do sistema nervoso (BESSON, 1999). Para alguns autores a dor crônica não pode ser mais definida apenas como aquela que persiste acima de um 
tempo determinado, por exemplo, maior que seis meses. Bonica propôs que a dor crônica é doença (dor patológica) e não tem o caráter protetor da dor aguda (dor fisiológica) (PRADO, 1999).

A dor crônica oncológica é de início geralmente insidioso, às vezes aumenta progressivamente com o crescimento do tumor, porém podendo diminuir com a regressão do tumor. Comportamento visível de dor e hiperatividade simpática podem estar ausentes, e a dor pode estar associada com distúrbios afetivos (ansiedade e/ou depressão) e com sintomas vegetativos, como a astenia, anorexia e distúrbio do sono. Exacerbações transitórias da dor intensa acima da dor moderada basal ou mínima são descritas como "breakthrough pain", talvez melhor traduzido para o português como dor incidental (CHERNY; PORTENOY, 1999b). Esta dor é tipicamente de início rápido, de intensidade moderada a severa ou intolerável, duração relativamente curta e está associada a agravamento funcional e psicológica do paciente (COLUZZI et al., 2001).

Ashburn e Saats (1999) resumem os tipos de dor em aguda, crônica e a dor relacionada ao câncer. Eles definem a dor aguda como aquela de duração curta (horas ou dias), associada a uma entidade patológica com prognóstico previsível, capaz de ativar o sistema de condução rápida e o sistema nervoso autonômico, com alto valor biológico, pouca repercussão social e que responde ao tratamento com analgésicos comuns. A dor crônica é resumida como dor de longa duração (meses a anos), comumente não associada a doenças, prognóstico imprevisível, associada à ansiedade e depressão, capaz de ativar o sistema de condução lenta, geralmente não associada à ativação do sistema autonômico, baixo ou ausente valor biológico, efeitos sociais profundos e requerendo tratamento 
multimodal. Na dor relacionada ao câncer a duração é imprevisível, usualmente uma enfermidade está presente e o aumento possível da dor pode acarretar sentimento de morte iminente e afetar o prognóstico. Está associada a muitos problemas, especialmente no sentimento de perda do autocontrole. Ativa vias de condução lenta, produz efeitos sociais variáveis, porém usualmente profundos e o tratamento deve ser multimodal quando as drogas têm grande utilidade no seu controle.

A dor é dita como nociceptiva se os mecanismos mantenedores da dor estão relacionados a uma lesão tecidual. A dor nociceptiva é usualmente classificada em somática e visceral, conforme a natureza da lesão tecidual. Dores são usualmente denominadas de neuropáticas se há evidência de que está associada à lesão de tecido nervoso e é sustentada por um processo somatossensorial aberrante na periferia ou no sistema nervoso central (CARACENI; PORTENOY, 1999). Esta condição pode estar presente com ou sem parestesia, hipoestesia, hiperalgesia e alodínia (KINGERY, 1997). Resumidamente, a hiperalgesia é a sensibilidade exagerada a um estímulo doloroso, alodínia é a dor em resposta a um estímulo mecânico não nocivo e hiperestesia é a resposta anormal ao estímulo sensorial. A dor neuropática, uma vez desencadeada, persiste por meses, anos ou décadas, mesmo após a lesão ter desaparecido (MYERS, 1995).

Didaticamente, a dor oncológica pode ser classificada em dor de origem somática, visceral ou neuropática. A dor somática está associada a danos teciduais e resulta da ativação dos nociceptores periféricos tanto superficiais como profundos. A qualidade da dor somática é descrita como sendo localizada, bem definida, como lancinante, cortante, dolorida, latejante, pulsante ou em aperto. 
A dor visceral têm certas características que lhe são peculiares. As vísceras podem ser insensíveis a determinados estímulos, como na destruição do parênquima do pulmão, do fígado ou dos rins provocado por um tumor maligno, enquanto o envolvimento da cápsula destes órgãos provoca dor (REGAN; PENG, 2000). Estímulos dolorosos em outros órgãos, como os causados por um corte ou queimadura não geram dor nas vísceras, mas a distensão de vísceras ocas pode causar dor. Então a dor visceral depende da natureza do tipo de estímulo nocivo. Características da dor visceral a tornam distinta da dor somática. A dor visceral é por vezes difusa, mal localizada, algumas vezes referida em outras estruturas, podendo estar acompanhada de reflexos autonômicos e motores, como náuseas e vômitos, e é mediada por fibras C (RIGOR, 2000; CERVERO; LAIRD, 1999). A qualidade da dor visceral pode ser descrita como cólica, câimbra, torcendo quando, p.ex., é causada por obstrução de víscera oca, ou descrita como facada, cortante, dolorida quando causada por distensão da cápsula do fígado.

Quando há estiramento, compressão ou distensão visceral, os nociceptores viscerais são ativados. Recentemente foram descritas duas classes de nociceptores viscerais. A primeira classe é representada pelos receptores que são ativados apenas por estímulos de alto limiar, como os mecânicos. Estes receptores são encontrados no coração, pulmão e vias aéreas, veias, esôfago, vias biliares, intestino delgado, cólon, ureter, bexiga urinária e útero. A segunda classe é composta por receptores que respondem a estímulos de baixo limiar e decifram a magnitude da intensidade de suas descargas. Foram descritos no coração, esôfago, cólon, bexiga urinária e testículos (CERVERO; LAIRD, 1999). A presença de isquemia, hipóxia e inflamação local causam dor por ativarem receptores de alto limiar e receptores previamente silentes, além de haver liberação de mediadores 
inflamatórios locais resultando em sensibilização periférica, aumento e perpetuação da transmissão do estímulo nocivo (REGAN; PENG, 2000).

A informação sensorial visceral é mediada por fibras C amielinizadas que se dirigem da periferia para ambos os lados da medula espinhal, diretamente para os gânglios autonômicos. Os aferentes primários trafegam com as fibras simpáticas ou parassimpáticas para o gânglio da raiz dorsal e terminam na medula espinhal nas lâminas I e V. Não há neurônios que respondam exclusivamente aos estímulos viscerais. Dor referida (viscerossomática), náuseas e vômitos são condições associadas. A dor referida é localizada distante da origem e às vezes em estruturas somáticas, tais como músculos e pele. Os corpos celulares das fibras aferentes viscerais estão localizados no gânglio da raiz dorsal, como os nervos espinhais, junto com o corpo celular dos nervos sensoriais. Seus axônios são curtos e fazem sinapse com interneurônios e neurônios da vias ascendentes do corno dorsal de medula. Os axônios das fibras aferentes são extremamente longos, caminham das estruturas das vísceras para os gânglios. A sensação visceral aferente pode ser interrompida por bloqueios de gânglios com anestésicos ou neurolíticos (HORD, 1997).

A dor visceral oncológica pode também ser causada por infiltração de víscera sólida, como no estiramento da cápsula do fígado, rins e baço. O estímulo requerido para ativar os nociceptores aferentes viscerais contidos nos nervos esplânicos podem ser: torção ou tração do mesentério, distensão ou contração de vísceras ocas, irritação de superfícies de mucosa e serosa, obstrução, isquemia, e espasmo de músculo liso. O tumor pode induzir hemorragia para dentro da víscera sólida, causar distensão da cápsula e resultar em dor. A necrose provoca a liberação 
de substâncias algogênicas que sensibilizam os nociceptores mecânicos e químicos. A invasão tumoral em estruturas vasculares é outra causa de dor. A infiltração e obstrução dos vasos sangüíneos e linfáticos, edema tecidual, linfangite perivascular, isquemia, e vasoespasmo reacional, causam dor difusa, mal localizada que segue a distribuição de um nervo periférico (JOHNSON; PARRIS, 1997).

A lesão direta do tecido neural por infiltração tumoral, erosão ou dos tratamentos específicos do câncer podem resultar em condição nociva e de difícil tratamento, conhecida como dor neuropática (LEMA; ADLAKA, 1998). Durante a regeneração do tecido lesado ocorre sensibilidade exagerada às catecolaminas que é muito diferente do tecido neural normal. Como resultado, a regeneração pode ser ativada intensamente pelo simples funcionamento do sistema nervoso simpático (ROSENQUIST, 1999). Esta eventualidade dramática se estabelece independentemente do local da lesão, ou seja, nervos periféricos, raízes posteriores, medula espinhal ou certas regiões do cérebro. Há casos em que a lesão do sistema nervoso não é detectável, mas aparecem os sintomas típicos. Nos estágios avançados da doença oncológica aumenta a probabilidade de ocorrência de dor com componente neuropático e, então os recursos terapêuticos para a dor podem ser ineficazes.

A dor neuropática pode ser descrita como contínua ou lancinante, em queimação, agulhadas, formigamento, picada, em choque, latejante e outras qualidades (CHERNY; PORTENOY, 1999a). Os sintomas de dor neuropática podem ser resumidos assim: dor em uma área sem lesão tecidual e atribuída a compressão ou lesão de uma estrutura neural; dor descrita como disestésica (p.ex., queimação, 
agulhada) ou paroxística (p.ex., facada, semelhante choques); dor associada com disfunção sensorial, motora e autonômica (GROND et al., 1999).

\subsection{Síndromes dolorosas no câncer}

\section{Dor aguda oncológica}

No paciente oncológico, as síndromes de dor aguda podem ser classificadas em três categorias: a primeira categoria é a dor aguda devida a procedimentos e terapias, pós-punção lombar, pós-biópsia de medula, paracentese, associada à terapia com Strotium-89 e à síndrome da hiperalgesia por opióide espinhal; a segunda é a dor aguda pós-operatória como a dor associada a procedimentos terapêuticos do transplante de medula, embolização de tumor e da pleurodese, a dor associada à quimioterapia (como a dor da infusão intravenosa ou intra-arterial de medicação), cefaléia devida à quimioterapia, mucosite orofaringeana, a dor associada à terapia hormonal como a dor da ginecomastia dolorosa e a dor associada à radioterapia como as enterites e proctites agudas da radiação; a terceira categoria é a dor relacionada ao tumor ou à doença como a dor por colapso de vértebra ou fraturas patológicas, obstrução aguda dos ureteres, da bexiga ou dos intestinos, a cefaléia por hipertensão intracraniana e mialgia por infecção como na sepse ou nos abscessos (PORTENOY; LESAGE, 1999). 


\section{Dor crônica oncológica}

Cherny e Portenoy (1999a) classificam a dor crônica oncológica em duas categorias: síndrome dolorosa relacionada ao tumor e síndromes relacionadas à terapia do câncer. As síndromes de dor relacionadas ao tumor podem ser subclassificadas em: dor óssea (metástases ósseas múltiplas, síndrome vertebral, dor lombar por compressão medular ou epidural, síndrome dos ossos da pelve e acrometástases); artrites (osteoartropatia hipertrófica); dores musculares (câimbra, tumores de partes moles); dores faciais e cefaléias (tumor intracerebral, metástase para ossos da base do crânio, neuralgias cranianas, síndromes dos olhos e ouvidos); tumor envolvendo o sistema nervoso periférico (radiculopatias, plexopatias cervicais e braquiais, plexopatia lombo sacra, neuropatias periféricas dolorosas paraneoplásicas); síndromes dolorosas de vísceras e síndromes relacionadas a tumores miscelâneos (síndrome da distensão hepática, síndrome mediana retroperitoneal, obstrução intestinal crônica, carcinomatose peritoneal, dor perineal maligna, síndrome adrenal dolorosa, obstrução uretérica, dor oncológica ovariana, dor do câncer de pulmão) e síndromes nociceptivas paraneoplásicas (tumor relacionado à ginecomastia). As síndromes de dor crônica relacionada com a terapia do câncer podem ser reunidas em quatro grupos assim dispostos: síndrome dolorosa pós-quimioterapia (neuropatia periférica dolorosa crônica, necrose avascular da cabeça do fêmur, plexopatia relacionada à infusão intra-arterial, fenômeno de Raynaud); dor crônica associada à terapia cirúrgica (síndrome pós mastectomia, dor pós dissecção radical do pescoço, dor pós-toracotomia, síndrome do ombro congelado, síndromes de dor fantasma, dor do coto, mialgia pélvica póscirúrgica); síndromes dolorosas pós-radiação (plexopatias, mielopatia crônica pósradiação, proctites e enterites pós-radiação, osteonecroses). 
A intensidade de dor varia de acordo com o tipo de neoplasia, estadiamento, extensão da lesão, presença ou não de metástases. Os mecanismos pelos quais os tumores produzem dor incluem obstrução linfática e vasoconstricção, distensão visceral, edema e inflamação tecidual ou necrose (PATT; ISAACSON, 1996). Em $20 \%$ ou mais dos casos, a dor pode ser devida à terapia anti-neoplásica (ex: quimioterapia induz a polineuropatias e mucosites; osteoradionecroses; dor pósmastectomia e pós-toracotomia).

\subsection{Tratamento da dor oncológica}

O manejo da dor oncológica depende de avaliação compreensiva das características dos sintomas em termos de patogênese, avaliação da relação da dor e a doença, e o impacto da dor e das co-morbidades preexistentes na qualidade de vida do paciente. Como a dor é inerentemente subjetiva, o paciente é o padrão ouro da avaliação. Devemos então avaliar as características da dor conforme a evolução temporal (início, causa e duração), localização (local primário e sua irradiação), intensidade (usualmente utilizamos a escala analógica visual [VAS], ou mensuração verbal como fraca, moderada, intensa ou intolerável), qualidade, fatores de piora ou melhora na dor. Estas características combinadas com o exame físico e revisão dos exames laboratoriais e de imagem usualmente definem a síndrome dolorosa (PORTENOY; LESAGE, 1999). 
Os princípios para o tratamento da dor no câncer incluem a escolha do analgésico conforme a intensidade da dor, o esquema de horário do uso das medicações, as doses resgates e o ajuste das doses conforme a necessidade individual de cada paciente.

Segundo a OMS, a dor oncológica deve ser tratada inicialmente por medicação analgésica oral seguindo a "Escada Analgésica de Três Degraus". A base deste princípio é a intensidade da dor, utilizando analgésicos fracos para dor fraca e analgésicos fortes para a dor intensa. O primeiro degrau corresponde à dor de baixa intensidade em que se utilizam os analgésicos fracos como os AINEs associados ou não a drogas coadjuvantes (antidepressivos, anticonvulsivantes, corticóides, bifosfonados). O segundo degrau corresponde à dor de moderada intensidade, em que se utilizam opióides fracos como a codeína, oxicodona e tramadol, associados ou não a coadjuvantes. No terceiro degrau, usam-se opióides fortes como a morfina, metadona, fentanil ou oxicodona. Quando não se obtém resposta a estas medicações, podemos utilizar técnicas analgésicas invasivas.

A escada analgésica é fundamentada na premissa de que a maioria dos pacientes de qualquer parte do mundo possa obter alívio adequado da dor se os provedores da saúde souberem utilizar algumas drogas que são efetivas, relativamente baratas e administradas por via oral, em intervalos regulares e de acordo com a necessidade individual de cada paciente (JADAD; BROWMAM, 1995). Os analgésicos devem ser oferecidos em esquema fixo de intervalos, respeitando a via de administração e a farmacocinética de cada droga. Deve-se evitar o uso do esquema "se necessário", para que o paciente não apresente dor enquanto a concentração plasmática da droga caia (vale) ou até que uma nova dose seja 
oferecida e atinja sua concentração plasmática máxima (pico). Nestes "picos e vales", além da dose cada vez maior, o paciente apresenta o desconforto da dor e a insegurança de não ter sua dor aliviada continuamente (TWYCROSS, 1999). No esquema de intervalos fixos, evita-se este desconforto e mantém-se a dor controlada. A dose do analgésico deve ser titulada conforme a dor do paciente, aumentando-se a dose conforme a necessidade. Doses extras podem ser necessárias e o paciente deve ser orientado a recorrer a elas (dose regate). Normalmente, utilizam-se drogas de início rápido de ação. Pode ocorrer uma dor inesperada, de inicio rápido, intensidade alta, e fora do controle diferente da que o paciente apresentava, é a dor incidental. Neste caso, até que uma nova avaliação clínica seja realizada, o paciente deve estar orientado e preparado. Alguns estudos mostram que o fentanil, na apresentação transmucosa (pirulito de fentanil), possa ser usado nestes casos (COLUZZI et al., 2001; HWANG et al., 2003).

Os analgésicos não opióides são as drogas de primeira escolha na dor leve a moderada (primeiro degrau). Podem ser utilizados associados aos opióides (segundo e terceiro degraus) por apresentar analgesia aditiva, não produzirem tolerância e nem dependência física. Apresentam efeito máximo ou efeito-teto, ou seja, uma dose maior que a dose máxima não aumenta a analgesia, porém aumenta a toxicidade. O uso crônico destes medicamentos causa efeitos adversos indesejáveis como efeitos gastrointestinais (úlcera péptica), hematológicos (hemorragias), reações de hipersensibilidade, insuficiência renal, precipitação de insuficiência cardíaca, dentre outros (EISENBERG et al., 1994). Os analgésicos não opióides incluem os antiinflamatórios não esteroidais, a dipirona e o paracetamol. Estas drogas são muito úteis no tratamento da dor causada por metástase óssea, dores musculares e infiltração de músculos (LEVICK et al., 1988; EISENBERG et al., 
1994; MERCADANTE, 1997). Os antiinflamatórios não esterioidais (AINEs) são comumente usados para analgesia para reduzir a resposta inflamatória da periferia. Agem bloqueando a via da ciclooxigenase, prevenindo a formação de prostaglandinas, porém com vários efeitos colaterais. Existem duas formas de ciclooxigenases: a COX-1 e COX-2. A COX-1 (forma constitutiva) está sempre presente nos tecidos e está relacionada ao processo vascular da homeostase e à regulação da produção de suco gástrico e funções renais. A COX-2 (forma induzida) não é encontrada sob condições de normalidade, mas está relacionada à inflamação e pode ser produzida por diferentes estímulos tais como os hormonais, fatores de crescimento, mitoses, mediadores inflamatórios (citocininas) e endotoxinas (lipopolisacarídeos). Então, os analgésicos inibidores seletivos da COX-2 podem apresentar menor risco de efeitos gastrointestinais ou sangramentos quando comparada aos outros AINEs (BESSON, 2001).

Os opióides são tradicionalmente vistos como drogas de ação central. O efeito analgésico dos opióides depende de sua ação em estruturas supraespinhais (ativando as vias descendentes que controlam a entrada de estímulos nociceptivos na medula espinhal), em receptores células espinhais (hiperpolarizando neurônios nociceptivos espinhais e/ou reduzindo a liberação de neurotransmissores pelo terminal central do aferente primário), em receptores localizados em terminais periféricos, tanto nociceptivos quanto pós-ganglionares simpáticos (reduzindo o quadro de hiperalgesia periférica) (PRADO, 1999). Assim, a morfina exerce uma poderosa ação depressora medular, a qual é a base do uso clínico dos opióides por via espinhal. A morfina age também em nível supraespinhal, intensificando a atividade do sistema de controle descendente da nocicepção. Há evidências da existência de receptores opióides também em nível periférico. Estudos 
sugerem mecanismo periférico para o efeito analgésico pós aplicação local ou da administração sistêmica de agonistas opióides que não cruzam a barreira hematoencefálica (STEIN et al., 1991, STEIN, 1995; YANG et al., 1998; TEGEDER et al., 2003). Os receptores opióides são produzidos no corpo celular do aferente primário (gânglio da raiz dorsal) e transportados em direção central para terminais localizados no corno dorsal da medula e em direção periférica. Os receptores periféricos tornam-se ativos após o dano tecidual. Isto justifica a utilização de opióides na periferia, por exemplo, para controlar a dor pós-cirúrgica de joelho ou após artroscopia, ou ainda a administração tópica de morfina (STEIN et al., 1991; STEIN, 1995; YANG et al., 1998; ver SIDDALL; COUSINS, 1998; WOOLF; DECOSTERD, 1999; TEGEDER et al., 2003).

A via oral é desejada pela facilidade de administração, melhor adesão ao tratamento, facilidade do manuseio, não é dolorosa, pode ser utilizada em casa, têm baixo custo e é a preferida pela maioria dos pacientes. É uma via segura, mas tem início de ação demorado, pico plasmático tardio e duração de efeito duradouro em relação à via parenteral. Em certas situações, há necessidade de lançar mão de outras vias de administração, como acontece com pacientes com câncer de base de língua que não podem deglutir, ou quando o paciente apresenta náuseas e vômitos. A via retal pode ser uma alternativa ao tratamento e podemos utilizar, também, cápsulas de morfina de liberação controlada, oxicodona ou hidromorfona. Acredita-se que a potência dos opióides usados por via retal aproxima-se à da via oral (CHERNY; PORTENOY, 1999b). O uso prolongado desta via é desconfortável e o paciente pode não aderir ao tratamento. Outras vias podem também ser usadas, como a sublingual (morfina, fentanil, metadona e alguns analgésicos não opióides estão disponíveis também nesta apresentação), 
transdérmica (fentanil e buprenorfina), transmucosa (pirulito de fentanil), intranasal (fentanil) ou intravaginal.

As vias subcutâneas, espinhais e epidurais são utilizadas quando doses altas de opióides são necessárias para o controle adequado da dor. Para evitar injeções subcutâneas repetidas, pode-se instalar cateter subcutâneo como, p.ex., o scalp. Utilizando-se as vias epidural e intra-espinhal podemos associar outras drogas aos opióides, incluindo anestésicos locais, clonidina ou cetamina, que permitem efeito analgésico aditivo (EISENACH et al., 1995). Cateteres espinhais e epidurais podem permanecer por semanas a meses no paciente. Doses intermitentes ou infusão contínua podem ser utilizadas. Relato de caso de falência no controle da dor oncológica em um paciente tratado com opióide por via epidural, previamente tratado com doses maciças de opióides intravenosos, foi descrito por Tanelian e Cousins (1989). Neste caso, a melhora da dor foi obtida quando se associou anestésico local por via epidural em dose que não produziu bloqueio motor. Eisenach et al. (1995) usaram clonidina epidural em pacientes com dor neuropática de origem oncológica obtendo alívio da dor. Já Smitt et al. (1998) observaram 11 casos de abscesso epidural em 91 pacientes estudados chamando a atenção para as possíveis complicações do uso de cateteres epidurais como os abscessos e meningites.

Os opióides podem ser usados na dor moderada (segundo degrau) e na dor de forte intensidade (terceiro degrau) levando em consideração a sua potência. A distinção dos opióides em "fracos" ou "fortes" deve-se à dose necessária para produzir analgesia semelhante à produzida por 10mg de morfina via endovenosa. O objetivo do tratamento com os opióides é alcançar o máximo de 
analgesia com os menores efeitos colaterais, evitando a toxicidade associada à overdose e o inadequado controle da dor que acompanha as subdoses (PEREIRA et al., 2001).

A escolha de qual opióide a ser usado depende: da exposição prévia aos opióides, intensidade e natureza da dor, idade do paciente, extensão do tumor, eventual envolvimento hepático ou renal e doença concorrente preexistente (WHO, 1996). Os opióides fracos (segundo degrau) mais utilizados no Brasil são o tramadol, a codeína (pura ou associada a paracetamol ou AAS) e a oxicodona. O tramadol tem efeito central, liga-se a receptores opióides $\mu$ e inibe a recaptação de noradrenalina e serotonina. A codeína, muito difundida no Brasil pelo seu baixo custo, tem seu uso limitado, pois aumenta os efeitos colaterais quando usada em doses acima de 1,5mg/Kg de peso corporal. A oxicodona é um derivado sintético da tebaína e tem estrutura similar à codeína. O seu efeito analgésico dura entre 3-5 horas e pode ser utilizada por via retal. No Brasil, esta droga ainda possui alto custo.

No terceiro degrau utilizam-se os opióides fortes como a morfina, fentanil, oxicodona de liberação prolongada, buprenorfina e a metadona. Várias apresentações de opióides estão disponíveis no mercado. A morfina é a mais utilizada devido ao seu baixo custo, várias apresentações e ser bastante conhecida pelos profissionais. O efeito analgésico da morfina dura 4 horas, mas a dose efetiva varia por causa da variação individual da biodisponibilidade sistêmica. O uso da morfina deve ser ditado pela intensidade da dor, e não pela expectativa de vida (WHO, 1996). O fentanil é um opióide potente e tem seu início de ação rápido. A apresentação endovenosa é alternativa na sala de urgência ou na dor incidental de forte intensidade. A apresentação transdérmica é alternativa em pacientes que estão 
impossibilitados para deglutir ou não toleram os efeitos gastrointestinais do uso da droga por via oral (AHMEDZAl et al., 1994; PAYNE, 1998; PAYNE et al., 1998). adesivo tem liberação contínua durante 72 horas, mantendo a concentração plasmática constante. Antes de iniciar esta droga, deve-se ter uma dose fixa de morfina ou outro opióide com analgesia controlada e então ver a dose eqüianalgésicas de fentanil. O paciente deve ser orientado quanto ao analgésico que irá usar, caso dose resgate seja necessária. Normalmente, usa-se a morfina de liberação rápida para os resgates. A buprenorfina é um agonista parcial e em doses altas pode ser tóxica, sem causar efeito analgésico aditivo (LEVY, 1996). Recentemente foi publicado o uso da buprenorfina transdérmica como alternativa no tratamento na dor crônica escruciante (SITTL et al., 2003). A metadona tem a meiavida longa e mantém a concentração plasmática estável, porém pouco se conhece sobre seus metabólitos. A metadona tem afinidade pelos receptores NMDA semelhante à da cetamina, além de se ligar fortemente aos receptores $\mu$ como a morfina, podendo ser útil na dor neuropática (MAKIN; ELLERSHAW, 1998).

Os opióides agonista-antagonistas e a meperidina devem ser evitados para uso crônico. Os agonistas-antagonistas (nalbufina) têm efeito máximo analgésico baixo e potencialmente podem reverter a analgesia. A meperidina deve ser evitada devido à sua meia vida curta e à toxicidade de seu metabólito, normeperidina (LEVY, 1996).

Os principais efeitos colaterais observados nos pacientes oncológicos com o uso contínuo de opióides são náuseas e vômitos, às vezes intoleráveis, principalmente nas primeiras semanas, obrigando-os à mudança da terapia. Constipação é o efeito colateral mais comum e piora com o aumento da 
dose; sedação e confusão mental são observados inicialmente e guardam relação com a dose utilizada. Retenção urinária é também freqüente, mas desenvolve tolerância. Depressão respiratória é rara no uso contínuo em pacientes com câncer porque a dose é balanceada com a dor e pode ser revertida com naloxona. Sintomas raros como prurido, broncoconstricção e sintomas psicóticos podem ocasionalmente ser vistos nos pacientes (CARACENI; PORTENOY, 1996). Outro efeito colateral ao uso dos opióides é a depressão do sistema imunológico observado em pessoas sadias e em pacientes oncológicos (YEAGER et al., 1995; SACERDOTE et al., 2000), o quê pode ser muito preocupante nos pacientes oncológicos pelo risco de infecção.

Doses eqüianalgésicas devem ser calculadas para a troca e rotação dos opióides quando a dor não é aliviada adequadamente ou quando a dose causa efeitos colaterais intoleráveis. A rotação de opióides pode ser útil na estabilização da relação analgesia/toxicidade. Pode ser trocado o opióide ou apenas a via de administração da droga. Substituir os opióides e usar doses mais baixas que o esperado de acordo com a dose equivalente é possível na maioria dos casos (MERCADANTE, 1999). A troca de um opióide por outro pode eliminar um efeito colateral incontrolável ou idiossincrático da droga inicial. Nestes pacientes, a dose do novo opióide pode ser calculada 25 a 50\% menos que a dose equivalente estimada, evitando tolerância cruzada (LEVY, 1996).

BERNABEl et al. (1998) realizaram estudo com 13625 pacientes com idade acima de 65 anos e observaram que os pacientes idosos são mal conduzidos e subtratados no controle da dor do câncer. Também encontraram tratamento inadequado nos pacientes de classe sócio-econômica baixa. Os 
pacientes idosos experimentam dor de similar intensidade (GANGLIESE; MELZACK, 2003), mas necessitam de doses de opióides menores do que as dos jovens (VIGANÓ et al., 1998). Outro trabalho mostra que os idosos têm qualidade diferente, mas intensidade de dor igual ao dos jovens .

As drogas adjuvantes pertencem a várias classes de medicações, e podem ser usadas em todos os degraus da "escada analgésica" quando necessário. Incluem os antidepressivos tricíclicos, os novos antidepressivos, anticonvulsionantes, corticóides, anestésicos orais, neurolépticos, antagonistas do receptor NMDA, baclofeno, clonidina e a calcitonina para o controle da dor neuropática. Os bifosfonados (p.ex., pamidronato), calcitonina, e radioterápicos (estrôncio-89 e samário) são usados na dor óssea. Na dor da síndrome dolorosa regional complexa, pode utilizar-se a clonidina, calcitonina ou prazosin, além de agentes tópicos como a capsaícina (AHMEDZAI, 1997; PORTENOY; LESAGE, 1999).

A dor neuropática é descrita como difícil de ser tratada e não responsiva aos opióides (KINGERY, 1997). Nestes pacientes, destacam-se o uso dos antidepressivos tricíclicos e os anticonvulsivantes. Os antidepressivos são efetivos no alívio da dor neuropática quando comparados com placebo (McQUAY et al., 1996). Grond et al. (1999), contradizendo KINGERY (1997), observaram que a dor neuropática não é intratável e pode ser tratada utilizando a terapia multimodal da OMS.

Muitas drogas, ou a associação delas na terapia multimodal, têm eficácia limitada. O controle total da dor muitas vezes não é atingido e a incidência de efeitos colaterais é muito alta (EISENACH et al., 1995). Em casos extremos, 
procedimentos invasivos, tal como a neuroablação, têm sido também preconizados. Os resultados ao longo do tempo demonstram alívio temporário e, às vezes, obtémse piora dos sintomas dolorosos (CHERNY; PORTENOY, 1999b). A literatura relata que a falência do tratamento da dor se deve a vários fatores relacionados com a evolução da doença em si e também com a terapia empregada, incluindo tolerância ao medicamento, intolerância aos efeitos adversos, drogas adjuvantes, efeito teto, dependência física, baixa eficácia e depressão respiratória, dentre outros (PATT; ISAACSON, 1996). O sucesso no manejo da dor crônica, especialmente nos pacientes com câncer, depende de estratégia polimodal, ou seja, vários medicamentos e estratégias utilizadas combinados com terapias multidisciplinares como técnicas fisiátricas, psicoterapia, musicoterapia, acupuntura, fisioterapia, e outras técnicas de relaxamento (p.ex., biofeedback e hipnose).

\section{Técnicas analgésicas}

Bloqueio de nervos são procedimentos que envolvem a administração de anestésicos locais, esteróides ou neurodestruição central de plexos viscerais ou de nervos periféricos e músculos. As técnicas analgésicas mais utilizadas são os bloqueios de gânglios do plexo celíaco, da cadeia simpática lombar, do plexo hipogástrico superior, do gânglio ímpar, do gânglio estrelado e da cadeia simpática torácica posterior. A neurólise do plexo celíaco com álcool ou fenol tem sido usada em pacientes com câncer pancreático e em outros tipos de câncer abdominal baixos. A cadeia simpática lombar tem sido neurolisada para tratar dores neuropáticas e a neurólise do plexo hipogástrico superior utilizada para controle da dor em tumores pélvicos (cólon descendente e reto, vagina, próstata, bexiga, uretra 
prostática, vesícula seminal, testículos, ovário e útero). O bloqueio do gânglio ímpar é utilizado para desordens do períneo (ASHBURN; STAATS, 2001).

O sistema nervoso simpático, como visto, tem sido alvo das neurólises. O sucesso em manejar a dor neuropática bloqueando os efeitos dos impulsos simpáticos é intrigante e ainda pobremente compreendido (MYERS, 1995). A interrupção da atividade contínua dos nociceptores através dos bloqueios com anestésicos locais ou agentes neurolíticos, bloqueando os gânglios simpáticos pode abolir a alodínia mecânica sem bloquear a atividade das fibras largas (WOOLF; MANNION, 1999). A analgesia provocada por bloqueio simpático é possível porque as fibras aferentes que inervam estas estruturas trafegam nos nervos, troncos, gânglios e ramos simpáticos (MERCADANTE et al., 2002).

Os agentes neurolíticos têm sido usados para interromper as vias da dor ao longo do século, tendo o primeiro relato sido publicado em 1863 por Luton, que injetou substância irritante por via subcutânea em áreas dolorosas (DITONTO; DE LEON-CASASOLA, 1998). Os agentes mais utilizados, atualmente, são o álcool e o fenol porque causam degeneração axonal em minutos e interrupção efetiva da transmissão dos impulsos dolorosos. A neurólise química pode resultar em alívio imediato e total da dor em pacientes selecionados com dor localizada ou regional (SEGHAL, 2003).

Interessado no manejo da dor incontrolável, Bonica (1954) publicou artigo mostrando sua experiência com bloqueios de nervos em 194 pacientes com câncer. Ele relata que 52,7\% dos pacientes tiveram alívio completo da dor, 33,5\% tiveram alívio parcial, porém dor suportável e o restante dos pacientes tiveram pequeno ou nenhum alívio. Bloqueio subaracnóideo com álcool foi descrito como 
eficaz e relativamente simples, com baixo nível de complicação para o tratamento da dor secundária à doença maligna (HAY, 1962). Novos tratamentos para a dor oncológica foram descritos na busca de alternativas quando o tratamento convencional já não é eficaz. Robertson (1983), como alternativa a neurólise intratecal, demonstrou o efeito analgésico produzido pelo bloqueio neurolítico transsacral em pacientes com carcinoma de reto. Foram descritos adormecimento e fraqueza após estes procedimentos. Incontinências urinárias e fecais são mais comuns após neurólise intratecal (SCHROEDER, 1986).

Os bloqueios de plexo celíaco e os bloqueios esplânicos são realizados rotineiramente e são preferidos à terapêutica convencional nos pacientes com dor intratável de origem oncológica pancreática ou cânceres gastrointestinais altos (SEHGAL, 2003). Estes bloqueios provêm alívio imediato e substancial em 7090\% dos casos, melhoram a qualidade de vida dos pacientes, e reduzem de forma significativa o consumo de opióides (EISENBERG et al., 1995; POLATI et al., 1998). A meta-análise realizada por EISENBERG et al. (1995) para estudo da eficácia e segurança do bloqueio neurolítico do plexo celíaco no tratamento da dor do câncer encontrou, no período de 1966 a 1993, 59 trabalhos, dos quais apenas 24 tinham dois ou mais pacientes. Dentre estes, apenas dois trabalhos eram randomizados e controlados. O estudo mostrou que $70 \%-90 \%$ do pacientes obtiveram melhora do seu quadro de dor. Os autores ressaltaram ainda que $32 \%$ dos trabalhos não utilizaram radioscopia na técnica do bloqueio e, como efeitos adversos, encontraram dor local (96\%), diarréia (44\%) e hipotensão (38\%).

Jones e Gough (1977) mostraram taxa de sucesso de 91\% no alívio da dor do câncer abdominal após neurólise do plexo celíaco. Patt e Millard (1990) 
relataram a importância da neurólise química no manejo da dor do câncer e na melhora da qualidade de vida dos pacientes oncológicos. Estudo prospectivo, randomizado e controlado descrito por Lillemoe et al. (1993) em pacientes com tumor não ressecável de pâncreas, realizou-se neurólise intra-operatória nos pacientes, independente da intensidade da dor e comparou-se com pacientes submetidos à injeção intra-operatória de salina (placebo). Os autores observaram redução importante na intensidade da dor, melhora na qualidade de vida e aumento da sobrevida dos pacientes submetidos à neurólise. Concluíram que a neurólise do plexo celíaco prolonga a vida dos pacientes por melhor controle da dor e suas repercussões sobre o humor, apetite, sono, complicações por imobilidade (infecções, trombose venosa profunda), menor consumo de analgésicos e menor freqüência de efeitos colaterais (náuseas e vômitos). De Leon-Casasola (2000) correlacionou o aumento da sobrevida dos pacientes do estudo de Lillemoe et al. (1993) ao uso de quantidades menores de opióide, com a melhora na preservação do sistema imunológico.

Os bloqueios neurolíticos do plexo celíaco têm sido utilizados também em pacientes não oncológicos portadores de pancreatite crônica com resultados não tão bons no alívio da dor quando comparados com o uso em carcinoma pancreático (LEUNG et al., 1983).

Para controlar a dor pélvica, Plancarte et al. (1990) realizaram estudo prospectivo não controlado de 28 pacientes com neoplasia pélvica em que a dor foi tratada com neurólise do plexo hipogástrico superior. Houve redução significativa e até eliminação da dor em todos os pacientes, sem complicações sérias. Neurólise do plexo simpático para tratar dor neuropática em pacientes não 
oncológicos foi abordado por Price et al. (1989) e reportado por Duthie e Ingham (1981) e Rosenberg et al. (1998) como tratamento não usual, mas com boa resposta clínica. Outros trabalhos sugerem eficácia dos bloqueios de plexo hipogástrico superior e encontraram excelente analgesia nos pacientes com dor pélvica oncológica e submetidos a este bloqueio, além de reduzir o consumo de analgésicos (PLANCARTE et al., 1989; DE LEON-CASASOLA et al., 1993; CARIATI et al., 2002). Recentemente, Mercadante et al. (2002) descreveram estudo prospectivo avaliando a utilização das neurólises dos plexos celíaco ou hipogástrico superior em pacientes oncológicos. Concluíram que os bloqueios são eficazes na redução do consumo de opióide e na intensidade da dor, mas não previnem a progressão da doença, a qual pode mudar os mecanismos de dor envolvidos. Para os autores há um envolvimento mais freqüente do componente neuropático na dor pélvica do que a dor abdominal, o que justificaria o maior alívio na dor pancreática pelos bloqueios simpáticos do que na dor pélvica oncológica.

O plexo celíaco tem localização retroperitoneal, atrás do estômago e pâncreas, na frente da coluna vertebral em nível T12-L1 e da crura do diafragma. Envolve a aorta abdominal e as artérias mesentéricas superior e celíaca. O plexo celíaco contém fibras aferentes viscerais e fibras eferentes simpáticas, bem como fibras parassimpáticas que passam pelas fibras pré-ganglionares (LEBOVITS; LEFKOWITZ, 1989). O gânglio celíaco é formado por fibras simpáticas do nervo esplâncnico, oriundas de T5 a T12 (grande esplâncnico, T5-T9; pequeno esplâncnico, T10-T11; e esplâncnico mínimo, T12), fibras pré ganglionares vagais e fibras sensoriais dos nervos frênicos. O plexo celíaco é formado por fibras eferentes de axônios pré-ganglionares que saem de T5 a T12 da medula espinhal com os axônios da raiz ventral através dos ramos comunicantes branco para a cadeia 
simpática, fibras simpáticas pós-ganglionares lombares superiores e fibras préganglionares parassimpáticas do vago e fibras aferentes viscerais (OLIVEIRA; SANCHES, 1995d; MERCADANTE; NICOSIA, 1998). O plexo celíaco é responsável pela nocicepção do abdômen superior, incluindo pâncreas, diafragma, fígado, vesícula biliar, baço, estômago, intestino delgado, cólon ascendente e porção proximal cólon transverso, adrenais, rins, aorta abdominal e mesentério, bem como os vasos sangüíneos do plexo celíaco. O bloqueio do plexo celíaco tem sido indicado para o tratamento da dor do câncer pancreático, dores abdominais e retroperitoniais (DE LEON-CASASOLA, 2000; MERCADANTE et al., 2003).

São descritas três técnicas de acesso para a realização do bloqueio do plexo celíaco visando a interrupção dos impulsos nociceptivos das vísceras do abdome superior: retrocrural (clássica), anterocrural e neurólises dos nervos esplênicos. Nestes três acessos, as agulhas são inseridas em nível de L1, 5 a 7 cm lateralmente a linha média. Então, a ponta da agulha é direcionada para o corpo vertebral de L1 na técnica retrocrural e anterocrural, e para o corpo de T12 para neurólise de nervos esplênicos (DE LEON-CASASOLA, 2000). Métodos de imagem como radioscopia, tomografia computadorizada, ultra-sonografia ou ultra-sonografia endoscópica são recomendáveis para a localização do plexo (ISCHIA et al., 1998; GRESS et al., 1999; DE CICCO et al., 2001). A avaliação da eficiência e efetividade da neurólise do plexo celíaco pode ser realizada através de parâmetros clínicos tais como diminuição do consumo de analgésicos, diminuição da intensidade da dor (VAS) e melhora da qualidade de vida do paciente.

As complicações associadas ao bloqueio do plexo celíaco são hipotensão arterial, que ocorre mais freqüentemente com o acesso retrocrural (50\%) 
ou esplênica (52\%) do que no acesso por via anterocrural (10\%). O bloqueio do simpático leva a vasodilatação periférica e conseqüentemente seqüestro de sangue na área esplâncnica, queda do débito cardíaco e hipotensão arterial. Diarréia transitória é mais freqüente com o acesso anterocrural (65\%) do que com a técnica do bloqueio dos nervos esplênicos (5\%) e acesso retrocrural (25\%). A diarréia ocorre por bloqueio simpático e, conseguinte, predomínio parassimpático tendo como efeito aumento do trânsito intestinal e do número de evacuações. A incidência de disestesia, dor interescapular dorsal, soluços, pleurite reacional, hematúria não encontrou diferença significativa entre as três técnicas (DE LEON-CASASOLA, 2000). A incidência de complicações graves é muito pequena, podendo ser paraplegia, disfunção urinária e intestinal (ABDALLA; SCHELL, 1999).

A cadeia simpática lombar consiste em axônios de neurônios préganglionares e pós-ganglionares. Os corpos celulares dos nervos pré-ganglionares se originam de T11, T12, L1 e ocasionalmente T10 e L3. Estes axônios deixam a medula espinhal pela raiz dos nervos espinhais anteriores correspondentes, unindo a cadeia com o ramo comunicante branco e então fazendo sinapse com o gânglio correspondente (RAJ et al., 1996). Impulsos dolorosos de estruturas viscerais e somáticas pode produzir dor mantida pelo simpático que pode ser de natureza somática ou visceral. Esta dor é transmitida por um par da cadeia paravertebral simpática que são facilmente acessíveis aos bloqueios. Neurólises do gânglio simpático quando efetiva observamos alívio da dor, aumento do fluxo sangüíneo e da temperatura dos membros inferiores. Eventualmente, observa-se parestesia em membros inferiores pós neurólise. Esta técnica é utilizada para tratar as dores irradiadas das plexopatias, dor do membro fantasma, herpes zoster, insuficiência vascular secundar a doença maligna e a síndrome dolorosa complexa regional, com 
pequeno risco de perda motora e sensorial ou dor por deaferentação (SEHGAL, 2003). Os bloqueios simpático lombares estão indicados ainda na dor oncológica de origem retal, cérvix ou perineal (FERRER-BRECHNER, 1989).

O plexo hipogástrico tem localização retroperitoneal e inicia-se, cranialmente, no terço inferior da quinta vértebra lombar até o terço superior da primeira vértebra sacral, perto da bifurcação da aorta. O plexo hipogástrico superior também possui fibras simpáticas e parassimpáticas que se dirigem às vísceras pélvicas (RIGOR, 2000). Estas fibras suprem a metade esquerda do cólon transverso e reto, útero e anexos, bexiga, uretra, testículos e próstata. O bloqueio deste plexo produz resultados semelhantes ao do plexo celíaco porque também as fibras aferentes que suprem a pelve trafegam nos nervos, troncos, gânglios e ramos simpáticos. A técnica é semelhante à usada para o plexo celíaco e é aconselhável o uso de métodos radiológicos como fluoroscopia e tomografia computadorizada (CARIATI et al., 2002) para a localização do plexo. As complicações relacionadas ao bloqueio não são relevantes (CARIATI et al., 2002).

Sehgal (2002) cita a neurólise do gânglio ímpar como útil para o alívio da dor perineal em pacientes com câncer de cérvix, endométrio, bexiga e reto. É um gânglio único, localizado retroperioneal, central e ventralmente à junção sacrococcígea. O fácil acesso torna a técnica trans-sacral utilizável nestes pacientes.

A dor oncológica ocorre comumente no contexto da evolução da doença, o que pode trazer múltiplos sintomas físicos e psicológicos, declínio funcional, estresse espiritual ou existencial, desordem familiar e financeira, levando a um declínio na qualidade de vida destes pacientes e familiares. O manejo efetivo na dor é uma necessidade emergencial. Existem várias condutas no tratamento da dor 
oncológica que precisamos saber como e quando utilizá-las para obter o melhor alívio da dor e do sofrimento do paciente e seus familiares. O controle efetivo da dor pode trazer melhora na qualidade de vida do paciente se este tratamento não causar efeitos colaterais insuportáveis ou não interferir no bem estar físico e mental do paciente. A terapia deve tratar a dor e melhorar a qualidade de vida do paciente sempre, talvez até prolongar a sobrevida destes, mas nunca piorar ou acrescentar sofrimento.

Como citado acima, os opióides são a base da terapêutica da dor oncológica, mas pode trazer efeitos colaterais indesejáveis. As técnicas anestésicas podem complementar com sucesso esta terapêutica, porém a OMS coloca estes procedimentos como um recurso final, quando a terapia com opióides falha. Entretanto, estudos demonstram que as neurólises dos plexos melhoram a qualidade de vida e até podem prolongar a sobrevida dos pacientes. Poucos trabalhos demonstraram o uso destes bloqueios na fase inicial da doença e nenhum comparou o uso destas neurólises com o momento desta intervenção. No presente trabalho propomo-nos a comparar o uso destas neurólises com a evolução da intensidade da dor. 


\section{OBJETIVOS}

Este trabalho tem como objetivo estudar comparativamente os efeitos de bloqueio de plexo executados precoce ou tardiamente sobre o controle da dor e/ou melhora na qualidade de vida de pacientes oncológicos com dor abdominal e pélvica, utilizando-se como controle, pacientes tratados farmacologicamente com analgésicos opióides segundo o esquema em escada proposto pela Organização Mundial de Saúde. 


\section{MATERIAL E MÉTODOS}

\subsection{Casuística e Método}

Para cumprimento do objetivo proposto, foi realizado trabalho prospectivo, randomizado e controlado, utilizando-se pacientes portadores de dor crônica de origem oncológica, encaminhados à Clínica para o Tratamento da Dor do Hospital das Clínicas da Faculdade de Medicina Ribeirão Preto-USP (HC-FMRPUSP). O projeto foi submetido e aprovado pelo Comitê de Ética em Pesquisa do HCFMRP-USP.

Os pacientes foram informados sobre o protocolo do estudo e esclarecidos sobre o objetivo do trabalho. Foi obtido também o consentimento por escrito de sua participação na pesquisa.

Foram inicialmente selecionados 60 pacientes com doença oncológica abdominal ou pélvica, e/ou com metástases em um destes dois locais. Cada paciente selecionado foi, então, alocado em um dos grupos experimentais (ver item 3.5) e, após avaliação clínica, foram incluídos no estudo os pacientes que apresentavam dor predominantemente abdominal ou pélvica em vigência de tratamento analgésico. 


\subsection{Avaliação da dor}

$\mathrm{Na}$ admissão dos pacientes neste estudo, foram analisadas clinicamente as características etiológicas e fisiopatológicas da dor por meio da história clínica, exame físico e revisão dos exames complementares do prontuário do paciente. Foram anotadas, após avaliação clínica detalhada, as características da dor em relação à intensidade, localização, duração, qualidade, irradiação e freqüência. Foram registradas as medicações analgésicas em uso e suas respectivas dosagens.

A intensidade da dor foi avaliada diariamente conforme as escalas apresentadas a seguir e registrado o valor informado pelo paciente de uma ou de ambas, conforme a facilidade de compreensão dos pacientes:

1. Escala Analógica Visual (VAS), correspondente a uma linha onde os extremos indicam a variação de dor desde: nenhuma dor (extremidade esquerda da linha), e pior dor imaginável (extremidade direita da linha).

2. Escala Analógica Visual Numérica de $10 \mathrm{~cm}$, que consiste régua numerada de zero a dez, sendo o valor "zero" representativo de ausência total de dor e o valor "dez", representativo de dor insuportável ou intolerável. 


\subsection{Avaliação do consumo de narcóticos}

Os pacientes receberam analgésicos conforme a intensidade da dor utilizando-se a "escada analgésica" da OMS e seguindo os princípios do guia para alívio da dor do câncer (WHO, 1996). O consumo de analgésico opióide foi expresso em termos de média de consumo diário durante uma semana. A porcentagem de variação do consumo de opióide em relação à avaliação inicial (linha basal) foi calculada e analisada estatisticamente.

\subsection{Avaliação da qualidade de vida}

A qualidade de vida de cada paciente foi avaliada segundo os sintomas estabelecidos pelo Questionário de Qualidade de Vida proposto anteriormente (KAWAMATA et al, 1996) (ver Apêndice). Os escores atribuídos foram assim definidos: a soma dos escores das questões de 1 a 6 corresponde aos fatores somáticos sensoriais, a questão de número 7 corresponde aos fatores psicológicos, a questão de número 9 corresponde aos fatores sociais, e as questões 8 e 10 aos fatores físicos e ocupacionais.

Os pacientes foram avaliados em cada retorno, realizados semanalmente ou em intervalos menores, durante oito semanas. Os dados foram anotados semanalmente sendo a primeira avaliação considerada o tempo inicial e as subseqüentes consideradas como tempos 1 a 8, correspondentes à primeira até oitava semanas. 


\subsection{Grupos experimentais}

Os pacientes selecionados foram inicialmente avaliados quanto ao valor da intensidade da dor conforme as escalas descritas acima. Todos os pacientes receberam terapia analgésica medicamentosa conforme o segundo e terceiro degraus da "escada analgésica" da OMS. Foram utilizados analgésicos opióides fracos como a associação de codeína (7,5 ou 30 mg) com paracetamol (500 mg) (Tylex ${ }^{\circledR}$ ) ou tramadol (50 ou 100 mg) (Tramal ${ }^{\circledR}$ ) associado ou não com AINEs (segundo degrau). Como opióide forte, utilizou-se morfina de liberação rápida (10 mg) (Dimorf $\left.{ }^{\circledR}\right)$ ou de liberação prolongada (30 mg) (MSLong $\left.{ }^{\circledR}\right)$, também associada ou não aos AINEs (terceiro degrau), visando manter VAS <4 (segundo escala numérica). Quando o VAS foi igual ou superior a 4, doses maiores foram utilizadas, seguindo o protocolo da OMS. A média de consumo diário de analgésicos narcóticos foi calculada a partir do consumo de opióides durante uma semana.

Os pacientes também receberam medicações coadjuvantes aos analgésicos (amitriptilina ou imipramina), por via oral, na dose de 12,5 mg/dia, aumentando-se a dose quando necessário, ainda seguindo as orientações do guia de tratamento da dor do câncer da OMS.

Os pacientes foram aleatoriamente alocados em três grupos de 20 pacientes cada.

\section{Grupo I: Bloqueio Precoce}

Neste grupo os pacientes foram submetidos a bloqueio e neurólise de plexos quando em vigência de uso de opióide fraco ou forte (morfina) em dose 
inferior a 90mg/dia, portanto enquadrados no segundo e terceiro degraus da "escada analgésica". Foi considerado como tempo inicial a avaliação feita no dia da intervenção. O procedimento utilizado foi um dos três bloqueios: celíaco, simpático lombar ou hipogástrico, determinado pelo local da dor. Após a neurólise, os pacientes receberam analgésicos narcóticos, conforme a intensidade da dor, buscando manter o VAS $<4$, e foi anotado o consumo diário de analgésicos opióides. Seguimento semanal e anotações sobre efeitos adversos foram realizadas até o fim da observação, durante oito semanas.

\section{Grupo II: Bloqueio Tardio}

Neste grupo os pacientes fizeram uso de opióides fracos ou fortes conforme os degraus dois e três da "escada analgésica" em dose diária suficiente para manter o VAS < 4. Considerou-se a avaliação inicial quando o consumo de opióide forte (morfina), por via oral, atingiu dose igual ou superior a $90 \mathrm{mg} / \mathrm{dia}$. Nesta ocasião, o paciente foi submetido a um dos três bloqueios de plexo de acordo com o local da dor, como realizado no grupo I. O seguimento subseqüente foi realizado de forma semelhante ao utilizado no grupo I.

\section{Grupo III: Controle}

Neste grupo os pacientes foram tratados somente farmacologicamente utilizando analgésicos opióides conforme a necessidade individual e seguindo o esquema em escada proposto pela Organização Mundial de Saúde. Este grupo foi utilizado como controle dos demais para o estudo da eficácia 
analgésica, dos efeitos adversos e da qualidade de vida. O seguimento foi realizado como no grupo I, mas sem a realização de neurólise de plexo.

Não se utilizou grupo tratado com placebo devido a questões éticas (ASA Guideline 1996, em Practice Guidelines for Chronic Pain Management). Este trabalho está, também, em concordância com os princípios básicos da ética para o manejo médico da dor estabelecido pela Academia Americana de Medicina da Dor (AAPM) em 1999.

\subsection{Seguimento dos pacientes}

Os procedimentos invasivos (neurólises) foram realizados no Centro Cirúrgico Ambulatorial do HCFMRP-USP. O seguimento dos pacientes foi realizado no ambulatorial. As avaliações clínicas foram feitas semanalmente com tempo de observação de 8 semanas. Efeitos colaterais dos narcóticos e/ou bloqueios, tais como perda do apetite, náuseas, vômitos, insônia, constipação, retenção urinária e diarréia foram anotados. Para quantificar cada sintoma, utilizou-se escala de escores de 0 a 3 , onde: 0 = sem sintoma; 1 = sintoma moderado; 2 = sintoma intenso, mas tolerável e 3 = sintoma intolerável.

\subsection{Critérios de exclusão}

Os critérios de exclusão para este estudo foram: tempo de observação menor ou igual a uma semana, realização de bloqueio utilizando 
anestésico local sem neurolítico, sítio de dor fora do abdome ou pelve, mudança de medicação e/ou da via de administração do analgésico em relação ao utilizado antes do bloqueio. Mudança na medicação e/ou via de administração, foi considerado critério de exclusão pela dificuldade de se comparar doses eqüianalgésicas dos medicamentos e das possíveis vias de administração, uma vez que não se tem consenso sobre as mesmas até a presente data (MERCADANTE, 1999; PEREIRA et al., 2001).

\subsection{Técnicas de bloqueio}

Os pacientes foram submetidos aos procedimentos em sala cirúrgica do Centro Cirúrgico Ambulatorial deste Hospital. Em todos os pacientes foram realizadas previamente punção venosa e administração endovenosa de RingerLactato. Monitorização contínua da freqüência cardíaca, pressão arterial e saturação de oxigênio foi realizada utilizando aparelho de monitorização modular (Dixtal®). Material apropriado para ressuscitação cardiopulmonar esteve disponível na sala cirúrgica durante o procedimento.

Sedação superficial suficiente para tirar a ansiedade do paciente foi realizada com uso endovenoso de midazolam (Dormonid $\AA$; 0,05 a 0,08 mg/kg). Foram realizadas assepsia local e infiltração da pele e tecido celular subcutâneo com lidocaína a 1\% sem vasoconstritor (Xylestesinß; $5 \mathrm{ml}$ para cada local de punção), na direção do trajeto percorrido pelas agulhas. Utilizamos agulhas espinhais $(150 \times 9$ ou $150 \times 8)$ da $B D \circledR$. Em todos os procedimentos foi utilizada fluoroscopia para a localização das estruturas e o contraste foi o diatriazoato sódio e 
diatriazoato de meglumina à $76 \%$ (Pielograf ${ }^{\circledR}$, Darrow). O agente neurolítico escolhido foi álcool a 100\%, manufaturado e fornecido pela farmácia do Hospital em ampolas de $10 \mathrm{ml}$.

Ao término dos bloqueios, os pacientes foram encaminhados para sala de recuperação pós-anestésica até sua completa recuperação da sedação, ainda sob monitorização dos sinais vitais. Na ocorrência de hipotensão arterial pós bloqueio, infusão de Ringer-lactato e/ou vasopressor endovenoso (efedrina na dose de $0,05 \mathrm{mg} / \mathrm{kg}$ ) foram oferecidos quando a queda da PA foi superior a $20 \%$ da inicial. Os pacientes permaneceram internados no hospital sob observação de eventuais intercorrências por 24 horas.

\section{Bloqueio do Plexo Celíaco}

Para o bloqueio do plexo celíaco utilizamos a via retrocrural conforme a técnica descrita inicialmente por Kappis (1914) (apud RAJ et al., 1996) e refinada por Moore (1965) (apud MOORE et al., 1981; SINGLER, 1982; MOORE, 1982; BROWN et al., 1987; ISCHIA et al., 1992; MERCADANTE; NICOSIA, 1998). O paciente foi posicionado na mesa cirúrgica em decúbito ventral e com um coxim sob as cristas ilíacas a fim de corrigir a lordose e expor melhor as apófises espinhosas. Foram então, identificadas e marcadas as apófises espinhosas da décima segunda vértebra torácica e a primeira vértebra lombar. Os bordos inferiores da décima segunda costela foram também identificados e marcados. As agulhas foram inseridas bilateralmente em ângulo de $45^{\circ}$ em relação ao plano longitudinal e cefalicamente a $15^{\circ}$, para alcançar o corpo vertebral de L1. A inserção foi feita a cerca de $7 \mathrm{~cm}$ da linha média e lateral ao processo espinhoso de L1. Uma vez tocada a superfície óssea, as agulhas foram recuadas e reposicionadas, 
aumentando-se, progressivamente, a angulação da agulha em relação ao plano longitudinal, caminhando no corpo vertebral até a região anterior do corpo vertebral, 1 - $2 \mathrm{~cm}$ anteriormente. O posicionamento da agulha foi confirmado pela fluoroscopia e por injeção de contraste $(1-3 \mathrm{ml})$. A radioscopia foi realizada em projeção póstero-anterior e lateral. A confirmação se deu com a imagem das pontas das agulhas na frente do corpo vertebral de L1 e imagem do contraste difundindo cefálica e sacralmente pela região anterior dos corpos vertebrais de T12, L1 e L2. Após a confirmação da posição das agulhas, foram injetadas 3 - 5ml de anestésico local em cada agulha, a fim de reduzir a dor provocada pelo álcool. Após 5 min, álcool a 100\% em volume aproximado de 15 - $20 \mathrm{ml}$ foi injetado em cada lado (OLIVEIRA; SANCHEZ, 1995a).

\section{Bloqueio do Plexo Hipogástrico}

O plexo hipogástrico é uma estrutura retroperitoneal localizada bilateralmente ao nível do terço inferior da quinta vértebra lombar e o terço superior da primeira vértebra sacral. A técnica utilizada foi a descrita por Plancarte et al. (1990). Após garantir acesso venoso e a realização da sedação endovenosa, o paciente foi posicionado em decúbito ventral e com um coxim sob as cristas ilíacas, a fim de se corrigir a lordose. Localizaram-se os interespaços de L4-L5 e marcaramse as respectivas apófises espinhosas. Com o marcador de pele, marcou-se bilateralmente 5 - $7 \mathrm{~cm}$ da linha média ao nível do espaço intervertebral de L4-L5. Infiltrou-se a pele e tecido subcutâneo com lidocaína (5 -10 ml). Com a agulha orientada caudalmente a aproximadamente $30^{\circ}$ e a $45^{\circ}$ em relação à pele em direção ao corpo vertebral de L5, a agulha foi redirecionada até tocar o corpo vertebral de L5 e a seguir, reposicionadas para atingir a parte anterior do corpo 
vertebral. A posição das agulhas foi confirmada pela fluoroscopia com contraste (OLIVEIRA; SANCHEZ, 1995b). Então, injeção de 3 - 5 ml de lidocaína para aliviar a dor provocada pelo álcool, e 5min após, injeção de álcool (10 - 15 ml) a 100\% foi realizada bilateralmente.

\section{Bloqueio do Simpático Lombar}

A cadeia simpática lombar encontra-se na face anterolateral dos corpos vertebrais e o gânglio simpático lombar ocupando mais freqüentemente o terço inferior da segunda vértebra lombar e o terço superior da terceira vértebra lombar (UMEDA et al., 1987). Utilizamos a via paramediana, conforme técnica descrita por Mandl apud Raj et al. (1996). Após garantir o acesso venoso e realizada a sedação, o paciente foi posicionado em decúbito ventral com um coxim sob o abdome, a fim de se corrigir a lordose. Foi traçada linha horizontal tangenciando a parte média do processo espinhoso de L2. A projeção desta linha corresponde ao espaço entre os dois processos transversos de vértebras subjacentes. Localizou-se um ponto sobre a linha traçada que diste $5 \mathrm{~cm}$ da linha média (OLIVEIRA; SANCHEZ, 1995c). Introduzimos, então, uma agulha em ângulo de $45^{\circ} \mathrm{com}$ o plano longitudinal em direção ao processo transverso até tocá-lo, reposicionando a agulha inferiormente e medialmente para escapar do processo transverso e tocar o corpo vertebral. Redirecionou-se, então, a agulha em direção à porção anterolateral do corpo vertebral. Repetiu-se o procedimento com outra agulha e confirmou-se o posicionamento com o auxílio de fluoroscopia e injeção de contraste (1 - $2 \mathrm{ml})$ pelas agulhas. Monitorização contínua da temperatura nos membros inferiores foi realizada com termômetro eletrônico (Dixtal $\left.{ }^{\circledR}\right)$ em contacto com a região plantar de ambos os pés. Injeção de 3-5 ml de lidocaína para amenizar a dor da alcoolinização 
e $5 \mathrm{~min}$ após foi realizada a neurólise com álcool a 100\% (7 ml). O aumento da temperatura dos membros inferiores auxiliou a confirmação do bloqueio do plexo simpático.

\subsection{Análise estatística}

A intensidade da dor (VAS), consumo de opióides e parâmetros de avaliação da qualidade de vida nos diferentes grupos experimentais comparadas pelo método de KRUSKALL-WALLIS, seguido pelo teste de MANN-WHITNEY. A intensidade da dor (VAS) foi expressa em gráficos como média ( \pm EPM). O consumo de opióides foi calculado pela porcentagem de consumo de cada narcótico em relação ao consumo basal. Dados demográficos foram avaliados empregando-se ANOVA seguida pelo teste de DUNNET. Em todos os casos estabeleceu-se $\mathrm{P}<$ 0,05 como nível para significância. 


\section{RESULTADOS}

\subsection{Comentários Gerais}

Dos 60 pacientes com câncer abdominal ou pélvico inicialmente alocados em um dos três grupos, foram excluídos 16 pacientes atendendo aos seguintes critérios: localização da dor fora do abdome ou pelve (2 pacientes); tempo de observação menor que uma semana (6 pacientes); realizado apenas bloqueio com anestésico local (5 pacientes) e mudança da via de administração do analgésico (3 pacientes). Assim, dos 60 pacientes inicialmente selecionados, somente 44 pacientes fizeram parte dos resultados deste trabalho, sendo que o grupo I ficou com 13 pacientes, o grupo II com 12 pacientes e o grupo III com 19 pacientes.

\subsection{Aspectos demográficos}

Os grupos experimentais não foram diferentes quanto à idade dos pacientes. A média de idade geral (média \pm EPM) em anos foi 58,07 $\pm 2,87,57,8 \pm$ 2,65 e 55,9 $\pm 3,4$ nos grupos I, II e III, respectivamente (Figura 1). Quanto ao sexo, a amostra total foi composta de 56,81\% (19) pacientes do sexo feminino e $43,19 \%$ (25) do sexo masculino. Vinte e oito pacientes $(63,63 \%)$ reportaram dor no abdômen e 16 pacientes $(36,36 \%)$ reportaram dor em região pélvica. Enquanto o local primário do 
tumor foi $65,9 \%$ (29) dos casos para tumor abdominal, 25\% (11) para tumor pélvico e 9,09\% (4) para outros tumores (Tabela 1).

Foram realizadas 14 neurólises do plexo celíaco (11 no grupo I, 3 no grupo II), 10 neurólises do plexo hipogástrico (2 no grupo I, 8 no grupo II) e uma neurólise do gânglio simpático lombar (no grupo I).

Tabela 1- Aspectos demográficos dos três grupos experimentais

\begin{tabular}{lccc}
\hline & GRUPO I & GRUPO II & GRUPO III \\
\hline SEXO F (M) & $7(6)$ & $4(8)$ & $8(11)$ \\
IDADE (EPM)* & $58,07( \pm 2,87)$ & $57,75( \pm 2,65)$ & $55,89( \pm 3,4)$ \\
TEMPO OBSERVAÇÃO* & 12,69 & 12,75 & 8,47 \\
LOCAL DE DOR & & & \\
$\quad$ Abdominal & 11 & 4 & 13 \\
$\quad$ Pélvico & 2 & 8 & 6 \\
LOCAL 10 DO TUMOR & & & \\
$\quad$ Abdominal & 12 & 6 & 11 \\
$\quad$ Pélvico & 1 & 6 & 4 \\
$\quad$ Outro ou indeterminado & 0 & 0 & 4 \\
BLOQUEIOS NEUROLítICOS & & & \\
$\quad$ Celíaco & 11 & 3 & -- \\
$\quad$ Hipogástrico & 2 & 8 & -- \\
$\quad$ Simpático Lombar & 0 & 1 & - \\
\hline
\end{tabular}

*Idade (anos) e tempo de observação (semanas) estão expressos em média. Erro padrão da média (EPM). Os demais valores estão expressos em valores absolutos. 


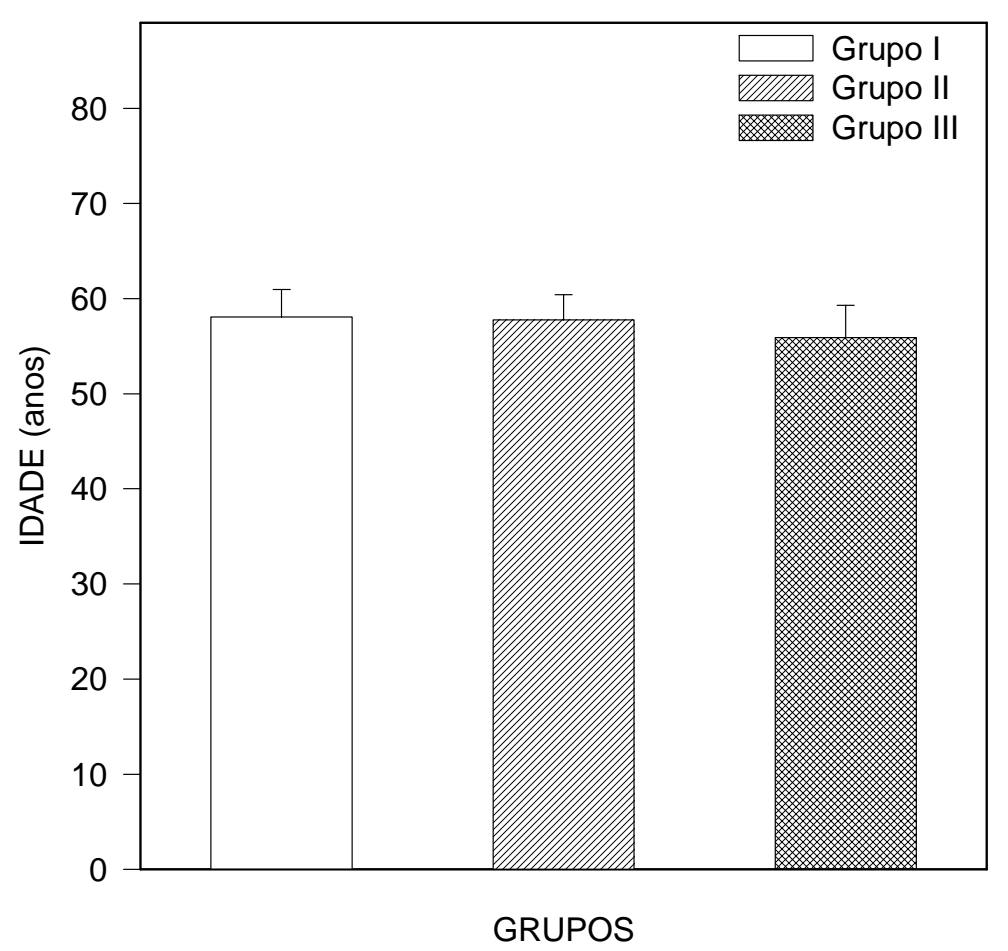

Figura 1- Média das idades (em anos) nos grupos experimentais. Grupo I (neurólise precoce), grupo II (neurólise tardia) e grupo III (controle). 


\subsection{Intensidade da dor (VAS)}

Não houve diferença significativa entre os grupos estudados quanto à intensidade inicial da dor (VAS). Após a neurólise, observou-se queda significativa do VAS nos grupos I e II em relação ao grupo III (controle) (Figura 2). Os grupos I e II não foram significativamente diferentes após a neurólise quanto à intensidade da dor, permanecendo ambos com valores baixos de VAS durante todo o período de observação (8 semanas). Alguns pacientes dos grupos I (6 pacientes) e II (4 pacientes) mantiveram o VAS $<4$ por períodos superiores a oito semanas pós neurólise, sendo que o tempo máximo de analgesia encontrado foi 27 semanas para o grupo I (1 paciente) e 34 semanas para o grupo II (1 paciente). No grupo III, o tempo máximo de observação foi de 26 semanas (1 paciente), porém o VAS encontrado foi igual ou superior a 4. Tais resultados não foram incluídos na análise por excederem o tempo proposto pelo projeto.

\subsection{Consumo de narcóticos}

Obteve-se diferença estatística significativa entre os pacientes dos grupos I e II que consumiram menos analgésicos opióides do que os do grupo III (Figura 3). O consumo de opióide no grupo III foi crescente e sistematicamente maior do que dos demais grupos durante as oito semanas de observação. Os pacientes dos grupos I e II não diferiram significativamente quanto ao consumo de opióide pós neurólise. 


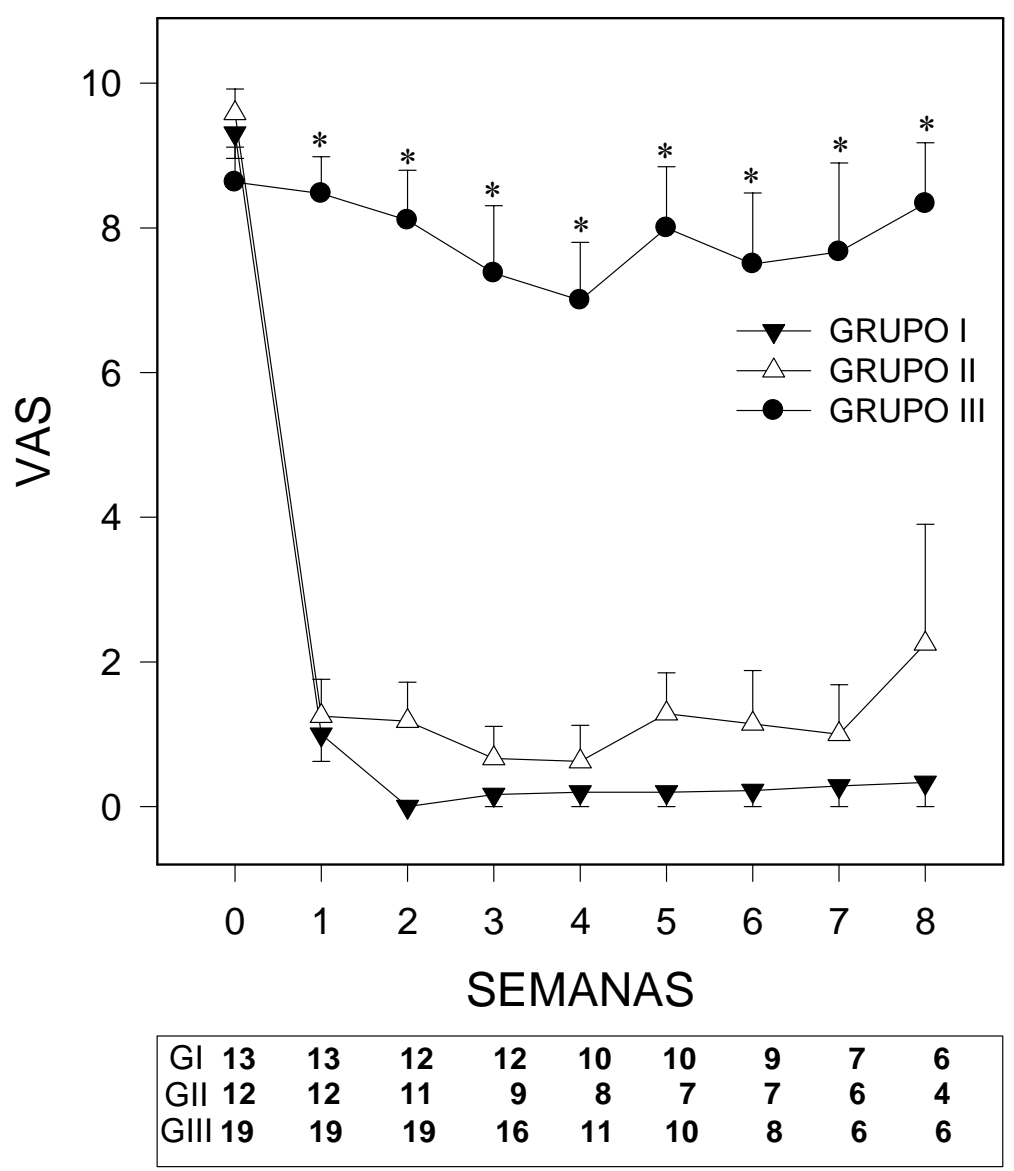

Figura 2- Média da intensidade da dor medida através da escala analógica visual (VAS de 0 - $10 \mathrm{~cm}$; onde $0=$ sem dor e $10=$ dor intolerável) nos grupos experimentais ao longo das 8 semanas de observação. O tempo zero corresponde à primeira avaliação e as neurólises ocorreram neste tempo nos grupo I (neurólise precoce) e II (neurólise tardia). O grupo III é o controle.

* diferente dos grupos I e II, $p<0,05$.

Abaixo, o número de pacientes, em cada grupo, nas diferentes semanas. 


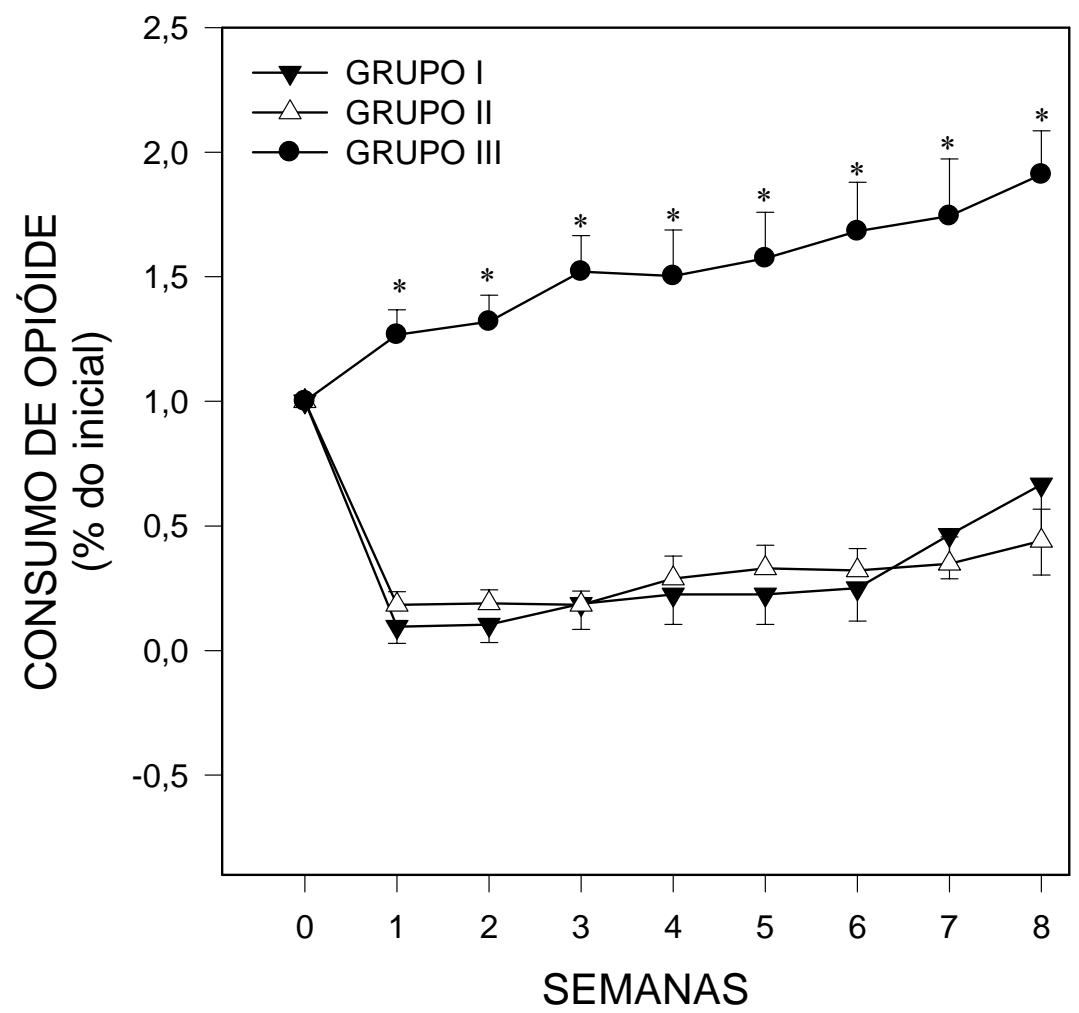

Figura 3- Variação do consumo de opióides em relação ao inicial (porcentagem) nos três grupos experimentais ao longo do tempo de observação (semanas), expressos em média. Os grupos I (precoce) e II (tardio) foram submetidos a neurólise no tempo zero. O grupo III é o controle.

* diferente dos grupos I e II, $p<0,05$. 


\subsection{Qualidade de vida}

Observou-se aumento do escore total no grupo III, significando piora na qualidade de vida neste grupo. Nos demais grupos obteve-se declínio destes escores para valores que permaneceram significativamente abaixo dos do grupo controle durante as 8 semanas de observação (Figura 4). Não houve diferença significativa, entretanto, entre os escores totais obtidos nos grupos I e II. Estes resultados indicam melhora significativa da qualidade de vida nos pacientes submetidos à neurólise, independentemente do procedimento ter sido precoce ou tardio.

Em relação aos quatro fatores do questionário de qualidade de vida a partir da segunda avaliação obteve-se redução no escores para os fatores somáticos (Figura 5) e psicológicos (Figura 6) nos grupos I e II, mas não no grupo III, com diferença significativa durante as 8 semanas. Os escores do fator físico nos grupos I e II foram reduzidos a partir da segunda avaliação e diferença significativa foi encontrada na maioria dos tempos de observação, exceto na sétima semana, quando não houve diferença em relação aos escores obtidos com o grupo III (Figura 7). Os grupos experimentais não foram diferentes quanto aos escores do fator social (Figura 8). 


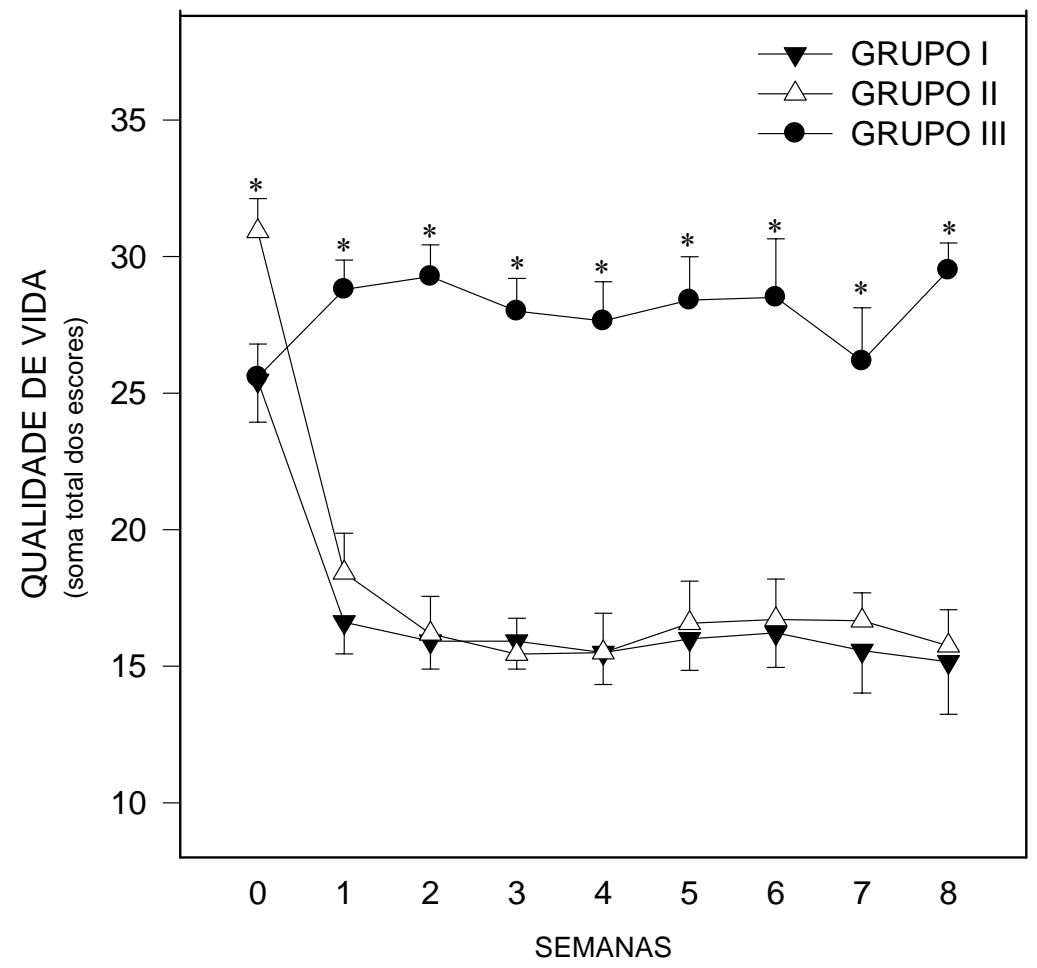

Figura 4- Média da soma total dos escores do questionário de qualidade de vida, em cada grupo, nas 8 semanas de observação, onde o valor mínimo é 10 e corresponde a melhor qualidade de vida e o valor máximo é 40 e representa a pior qualidade de vida. Os grupos I (precoce) e II (tardio) foram submetidos a neurólise no tempo zero. O grupo III é o controle.

* diferente dos demais grupos, $p<0,05$. 


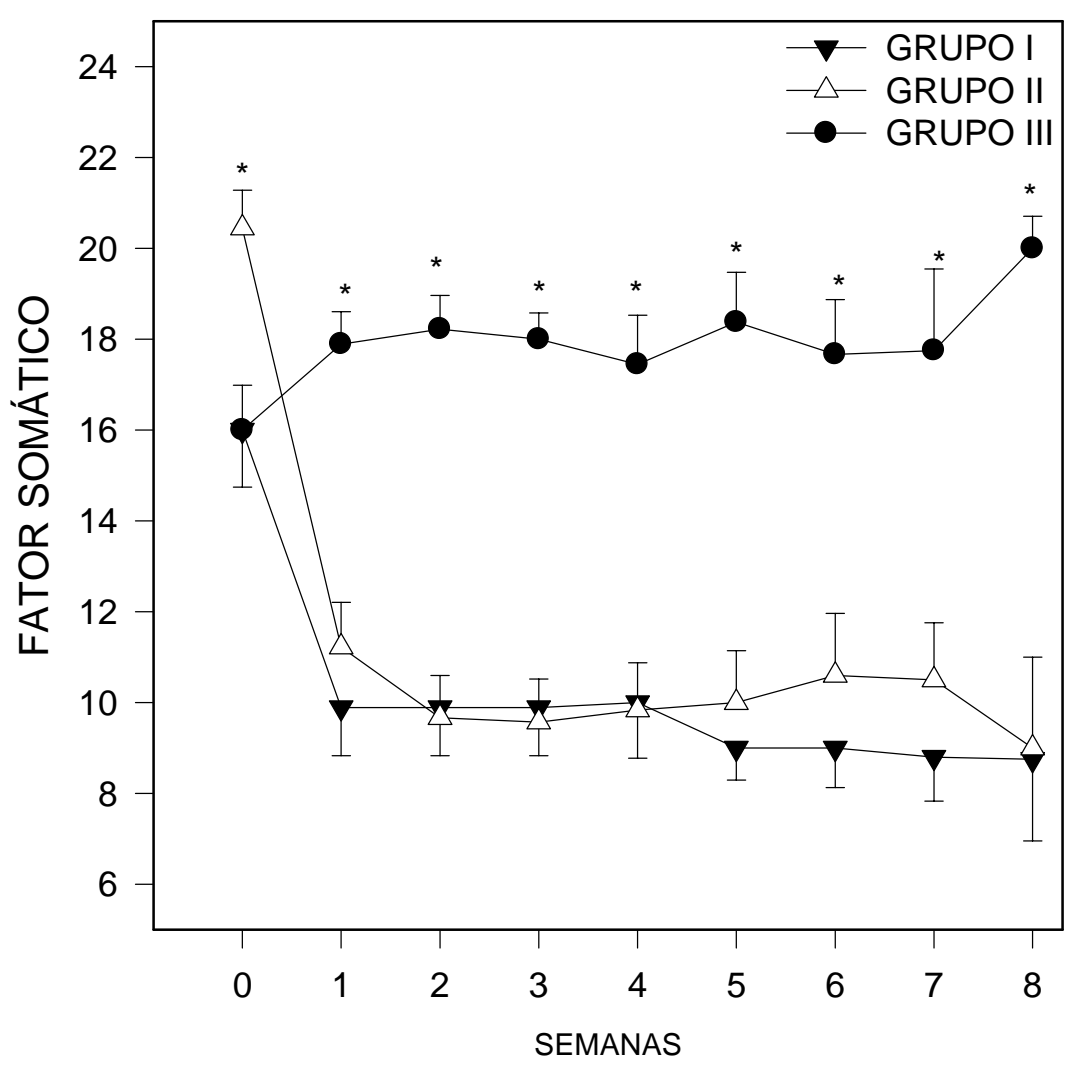

Figura 5- Média dos escores do Fator Somático do questionário qualidade de vida (QQV) durante as 8 semanas de observação, nos diferentes grupos. Onde valor máximo é 24 , corresponde a pior qualidade de vida e o valor mínimo é 6 , a melhor. Os grupos I (precoce) e II (tardio) foram submetidos a neurólise no tempo zero. $\mathrm{O}$ grupo III é o controle.

* diferente dos demais grupos, $p<0,05$. 


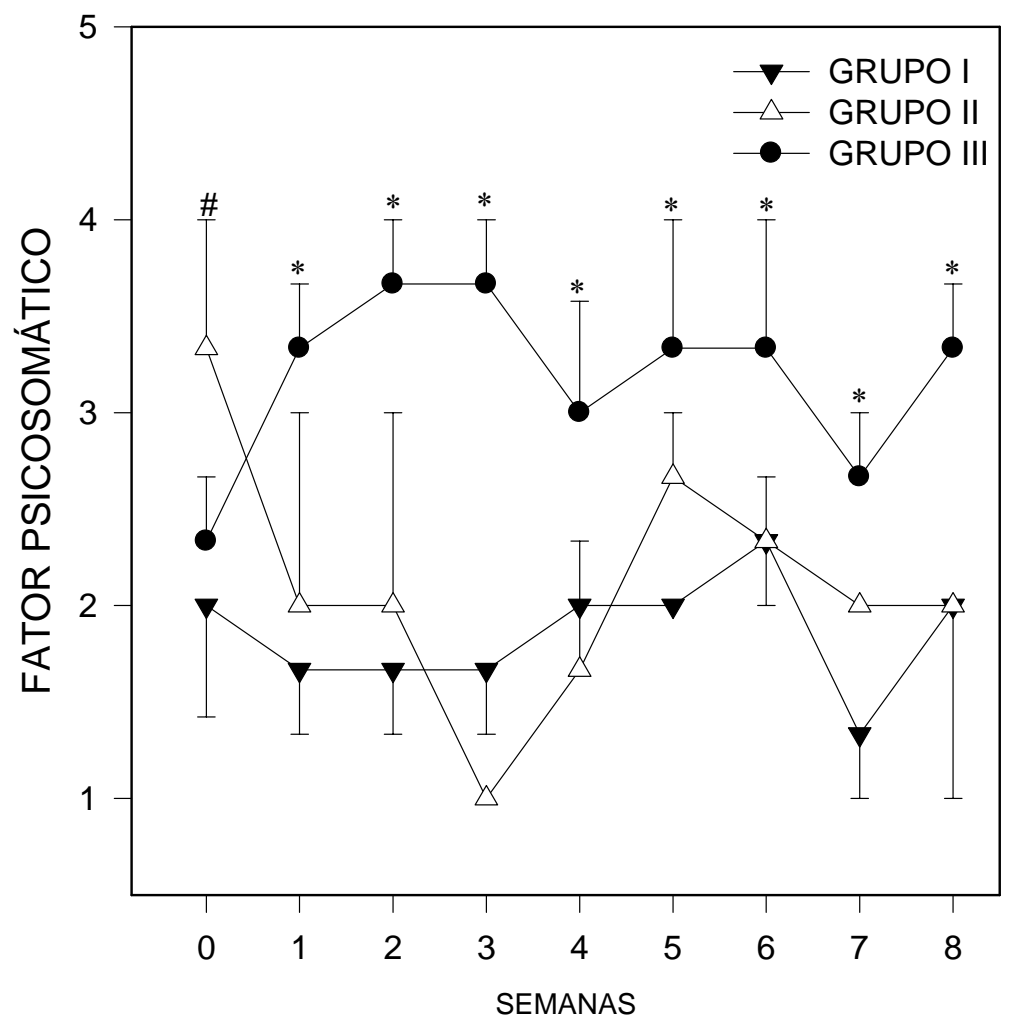

Figura 6- Média dos escores do fator psicológico ao longo das semanas de observação nos diferentes grupos. Valor máximo = 4 (pior escore); valor mínimo $=1$ (melhor escore). Os grupos I (precoce) e II (tardio) foram submetidos a neurólise no tempo zero. O grupo III é o controle.

* diferente dos demais grupos, $p<0,05$.

\# diferente do grupo III $(p=0,044)$. 


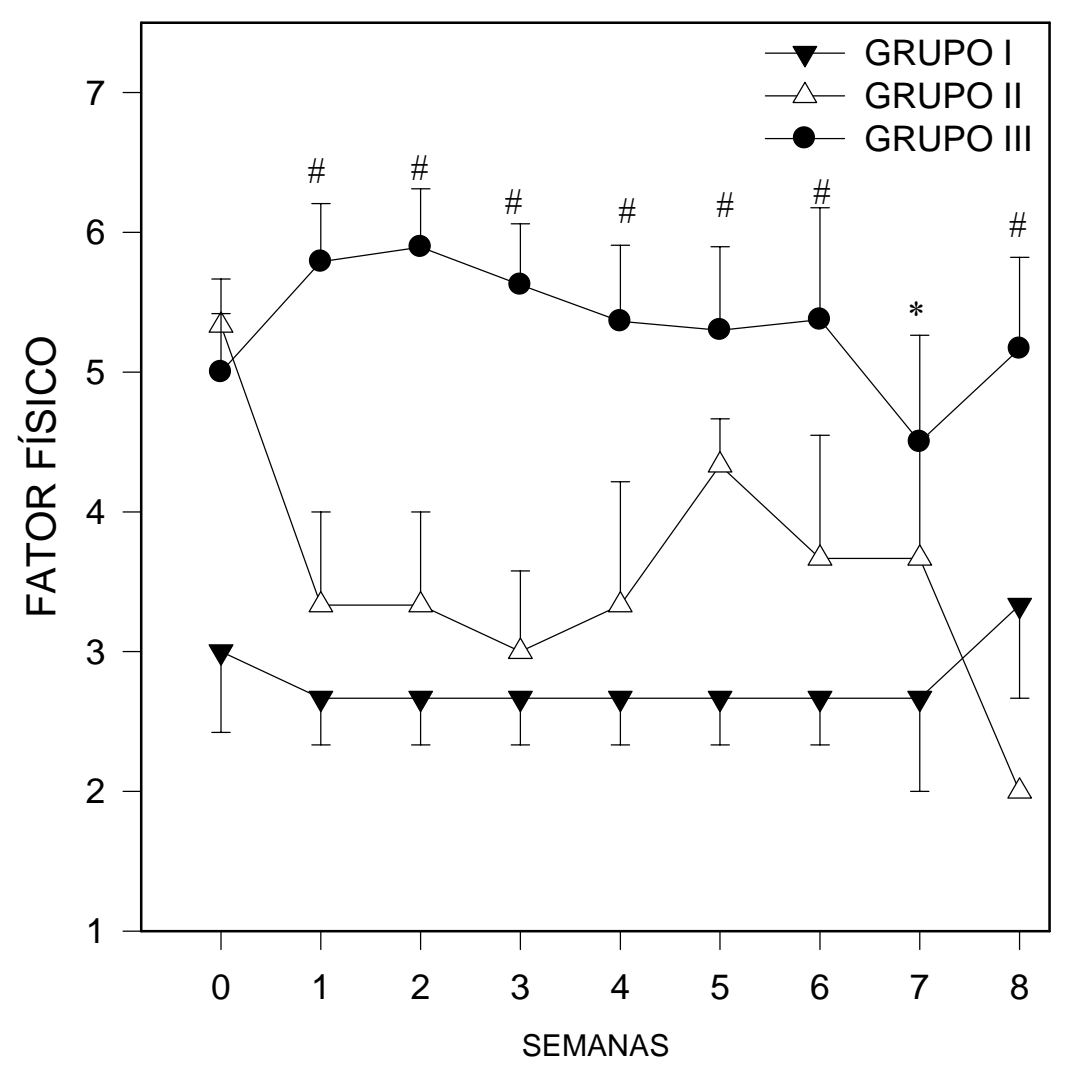

Figura 7- Média dos escores do fator físico e ocupacional nas diferentes semanas. Valor máximo $=8$ (pior escore); valor mínimo $=2$ (melhor escore). Os grupos I (precoce) e II (tardio) foram submetidos a neurólise no tempo zero. O grupo III é o controle.

\# diferente dos grupos I e II.

* diferente do grupo I, $p<0,05$. 


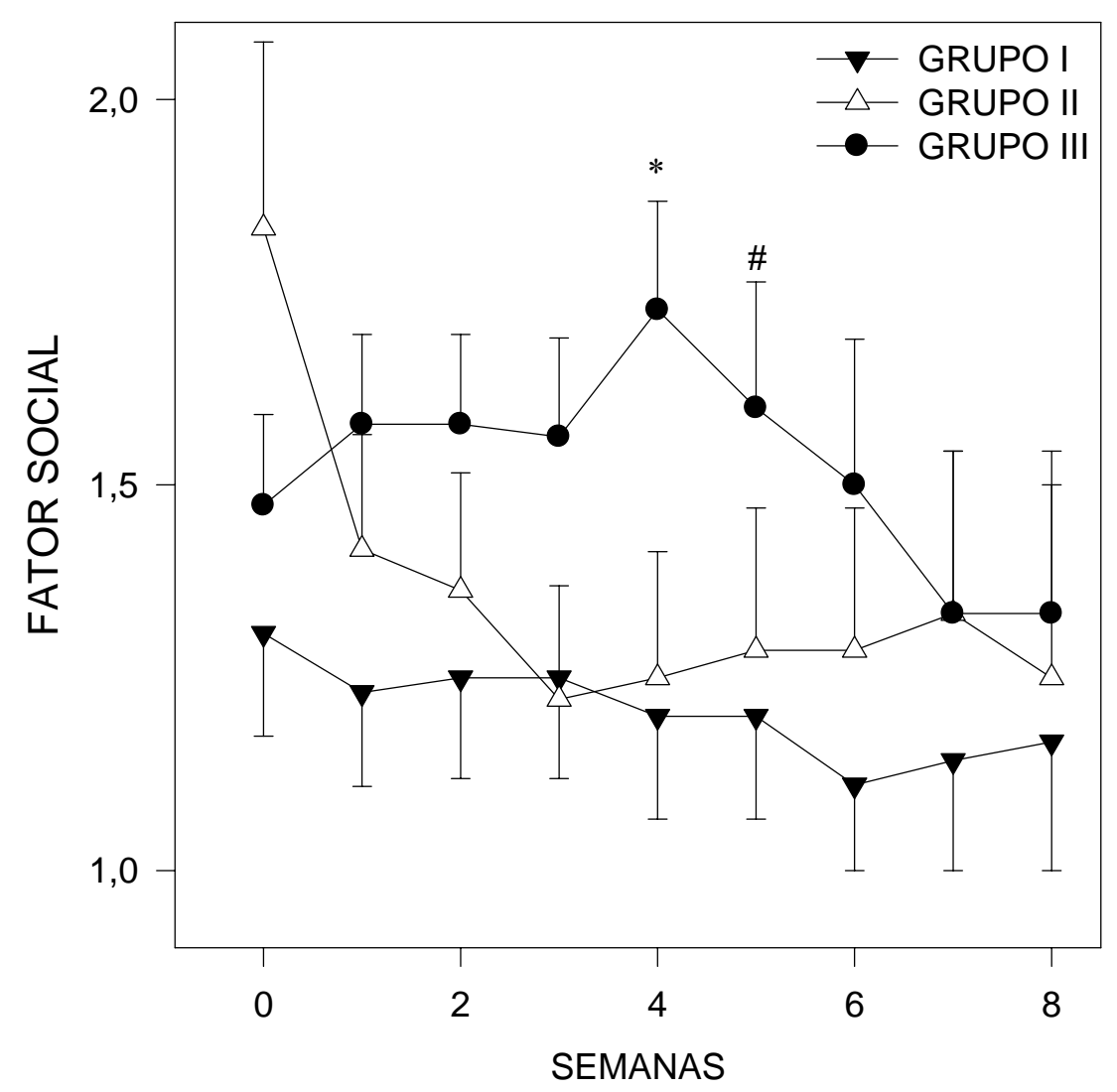

Figura 8- Média dos escores do fator social da qualidade de vida ao longo das semanas de observação. Valor máximo $=4$ (pior escore); valor mínimo $=1$ (melhor escore). Os grupos I (precoce) e II (tardio) foram submetidos a neurólise no tempo zero. Grupo III é o controle.

* diferente dos demais grupos.

\# diferente do grupo I, $p<0,05$. 


\subsection{Efeitos colaterais e complicações}

Alteração dos níveis pressóricos e da freqüência cardíaca foram anotados imediatamente antes (inicial) e 30 minutos (final) após a realização dos bloqueios. A média (média \pm EPM) da pressão arterial sistólica para o grupo I foi $120,92 \pm 8,09$ (inicial) e $98,23 \pm 6,3$ (final), para o grupo II foram $130,63 \pm 5,77$ (inicial) e 124,5 $\pm 7,85$ (final). As médias da pressão arterial diastólica para o grupo I foram $75,15 \pm 4$ (inicial) e 60,84 $\pm 3,59$ (final), para o grupo II foram 83,33 $\pm 3,09$ (inicial) e 75,83 $\pm 5,96$ (final) (Figura 9). As médias (média \pm EPM) das freqüências iniciais e finais nos grupos I e II, respectivamente, foram 90,69 $\pm 3,59$; 87,07 $\pm 4,2$; $93 \pm 3$ e 90,91 $\pm 5,83$ (Figura 10). Não houve diferenças significativas entre os grupos I e II em relação à variação dos níveis pressóricos (sistólica e diastólica), bem como da freqüência cardíaca.

Tratamento da hipotensão arterial após a realização dos bloqueios foi realizado em quatro pacientes (3 do grupo I e 1 do grupo II) com vasopressor (sulfato de efedrina). Infusão endovenosa de volume (solução de Ringer-Lactato) foi necessária em 6 pacientes (24\%). 


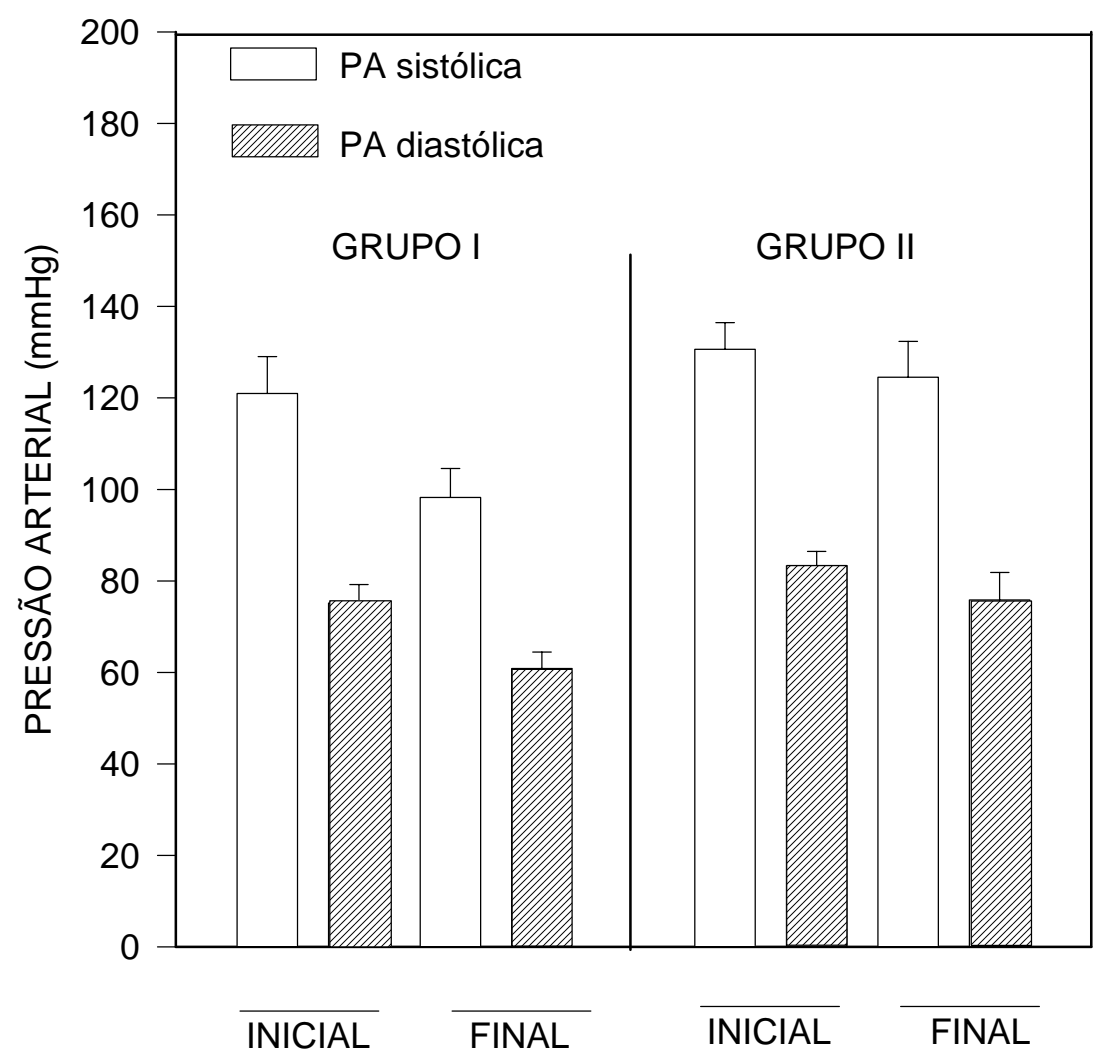

Figura 9- Média (média \pm EPM) das pressões arteriais sistólica (PA sistólica) e diastólica (PA diastólica), antes (inicial) e após (final) a neurólise nos grupos I (precoce) e II (tardio). 


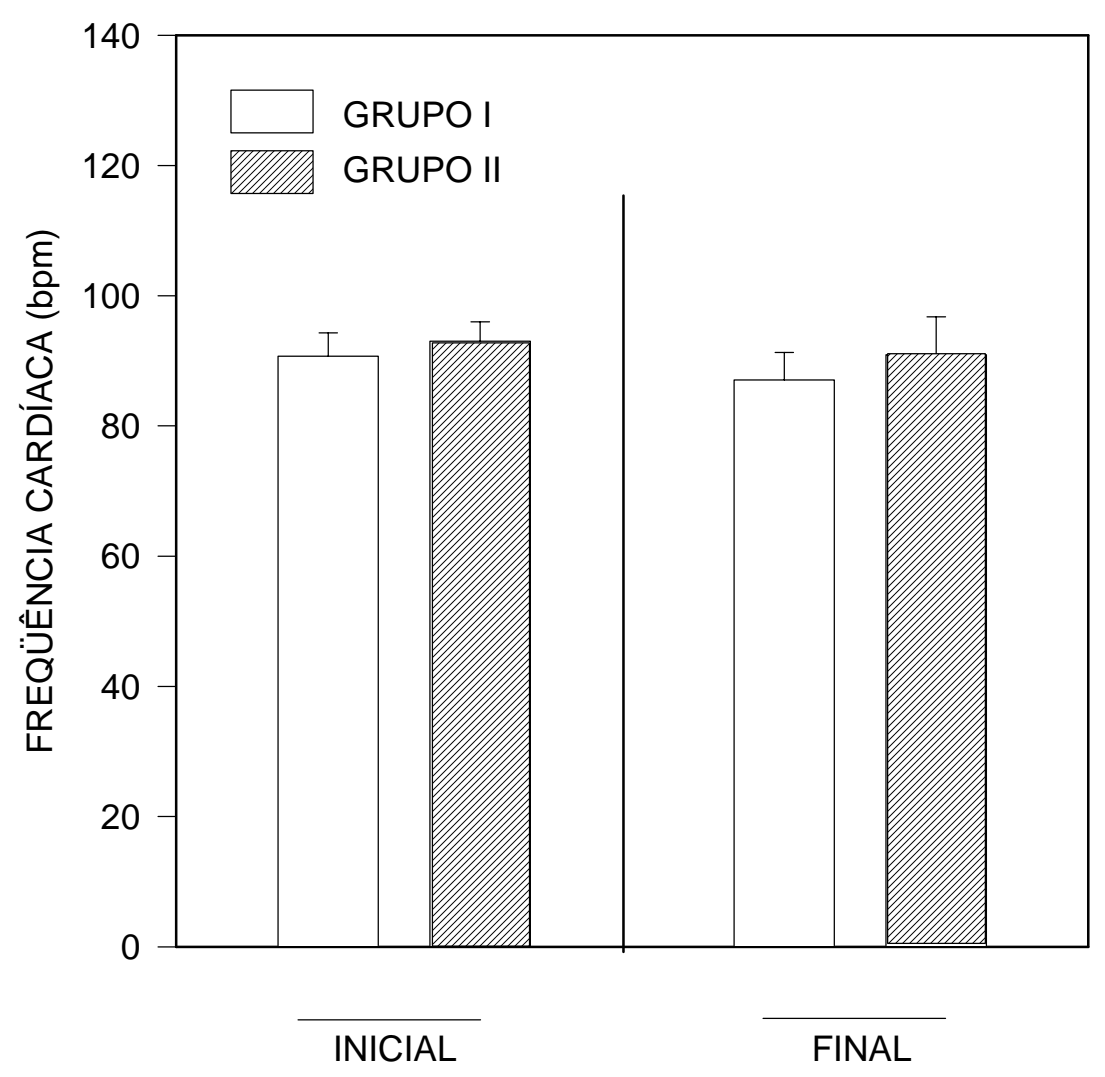

Figura 10- Média (média \pm EPM) das freqüências cardíacas (bpm) antes e após a neurólise nos grupos I (precoce) e II (tardio). 
Diarréia foi relatada em apenas 2 casos (8\%). Somente um paciente apresentou desidratação e, outro, apresentou diarréia e tontura durante a $1^{\mathrm{a}}$ semana, os demais apresentaram os sintomas nas primeiras 12 horas após o bloqueio. Ao longo do tempo não houve diferença entre os grupos no que se refere ao sintoma diarréia (Figura 11).

Foram observados os efeitos colaterais mais freqüentes em pacientes oncológicos que utilizam opióides, como: diminuição do apetite, náuseas e vômitos e constipação. A freqüência destes efeitos foi anotada e observamos que a diminuição do apetite foi mais freqüente no grupo III, enquanto que o apetite manteve-se preservado nos grupos I e II com os escores de freqüência menores (Figura 12).

Os grupos I e II obtiveram escores de náuseas e vômitos significativamente menores que o grupo III nas primeiras três semanas de observação, mostrando que o grupo controle apresentou mais este efeito colateral (Figura 13). Porém observamos constipação menos freqüente no grupo I em relação aos grupos II e III. No grupo II, houve uma queda na freqüência da constipação, mas sem diferença significativa entre o grupo III (Figura 14). Efeitos colaterais ocorreram como sonolência (4 pacientes do grupo III e nenhum nos grupos I e II), tontura (2 do grupo I, 3 do grupo III e nenhum no grupo II) e retenção urinária (1 do grupo II, 1 do grupo III e nenhum do grupo I). Soluços, incontinência urinária, dispnéia, astenia, ascite, sudorese e hematúria foram observadas em casos isolados e sem diferenças entre os grupos. 


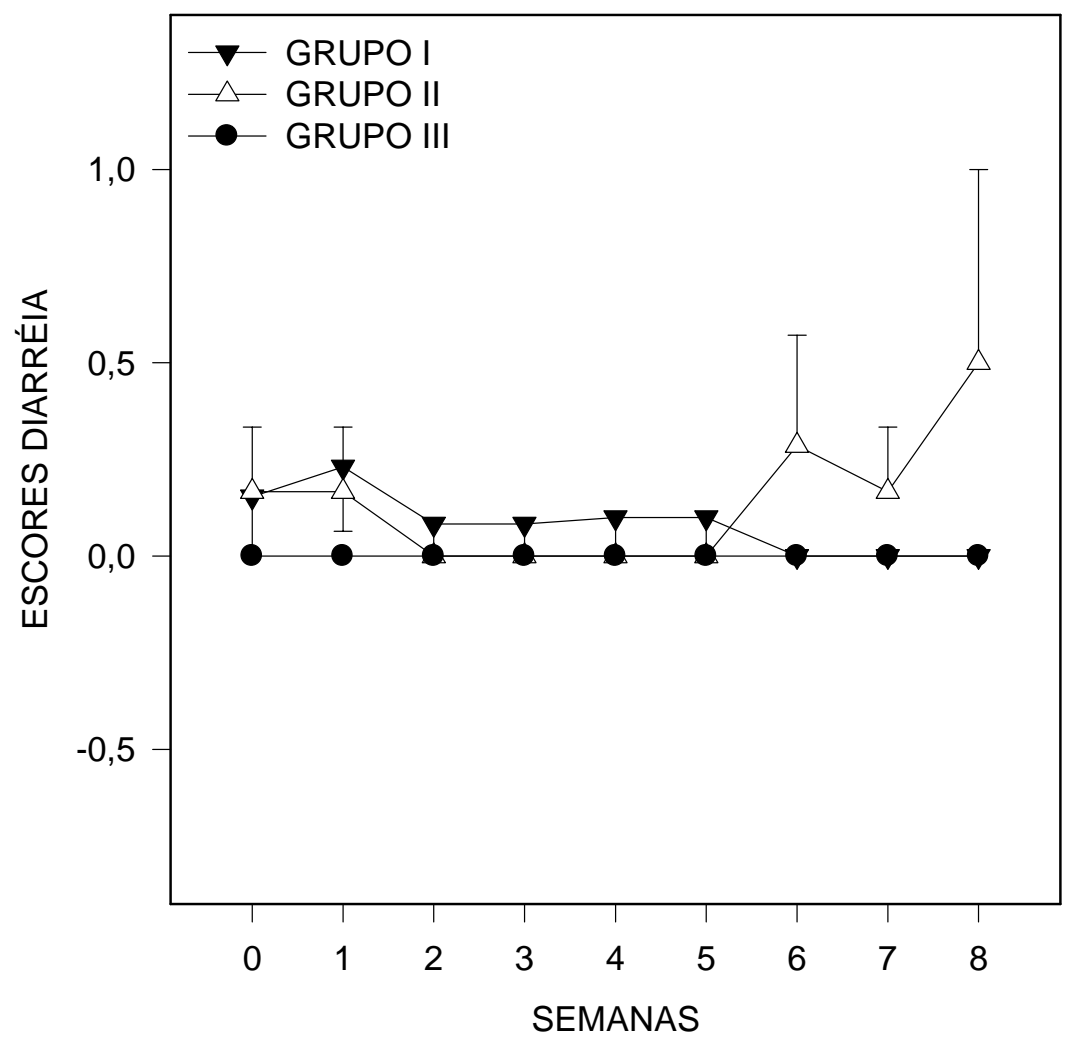

Figura 11- Média (média \pm EPM) do sintoma diarréia ao longo do tempo de observação ( 0 = sem sintoma; $3=$ diarréia intolerável). Grupos I (precoce) e II (tardio) foram submetidos a neurólise no tempo zero. Grupo III é o controle. 


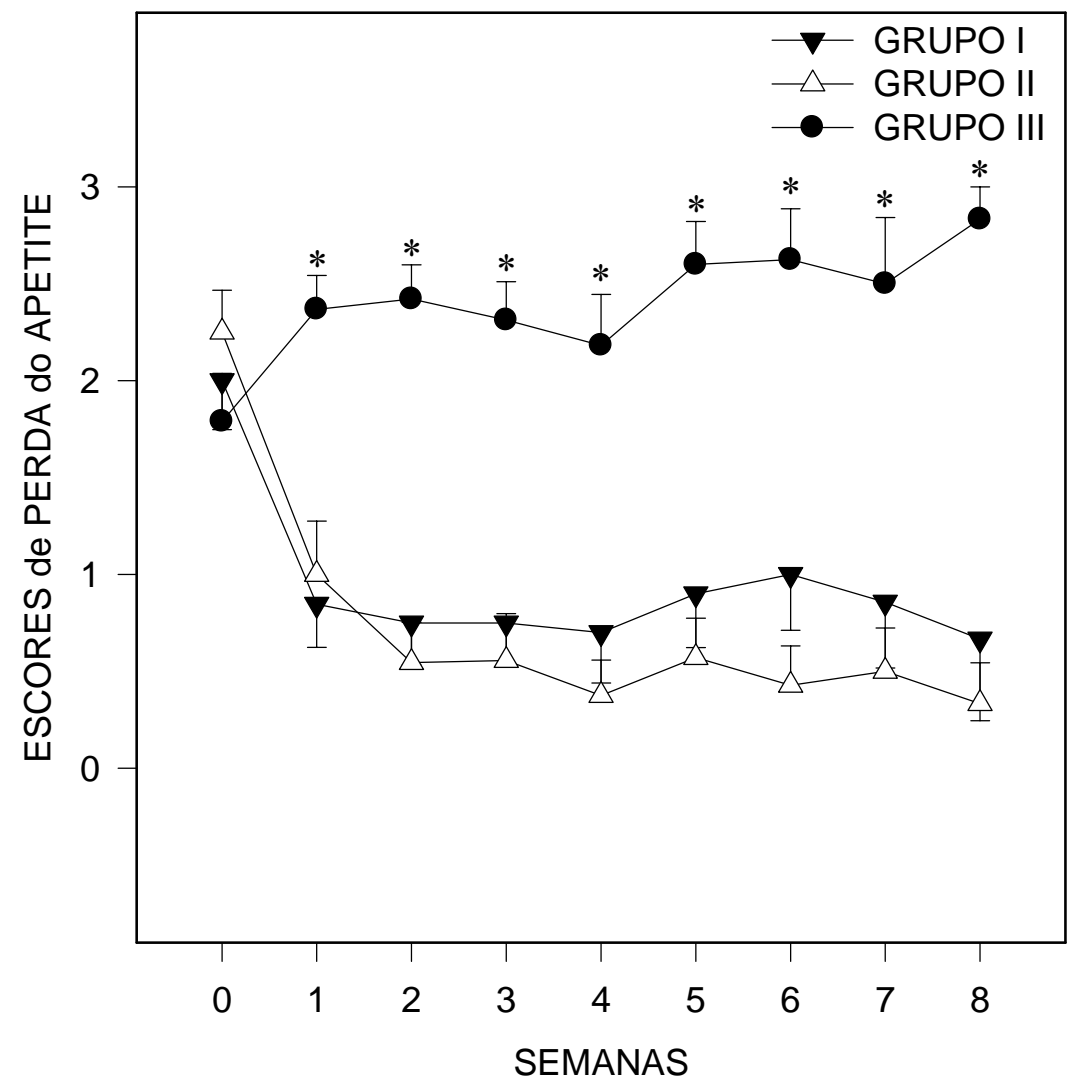

Figura 12- Média dos escores do sintoma perda do apetite ao longo do tempo de observação nos diferentes grupos. Os valores dos escores são de 0 a $3(0=$ apetite preservado; $1=$ apetite razoável; 2 = apetite ruim; $3=$ não come). Os grupos I (precoce) e II (tardio) foram submetidos a neurólise no tempo zero. O grupo III é o controle.

* diferente dos demais grupos, $p<0,05$. 


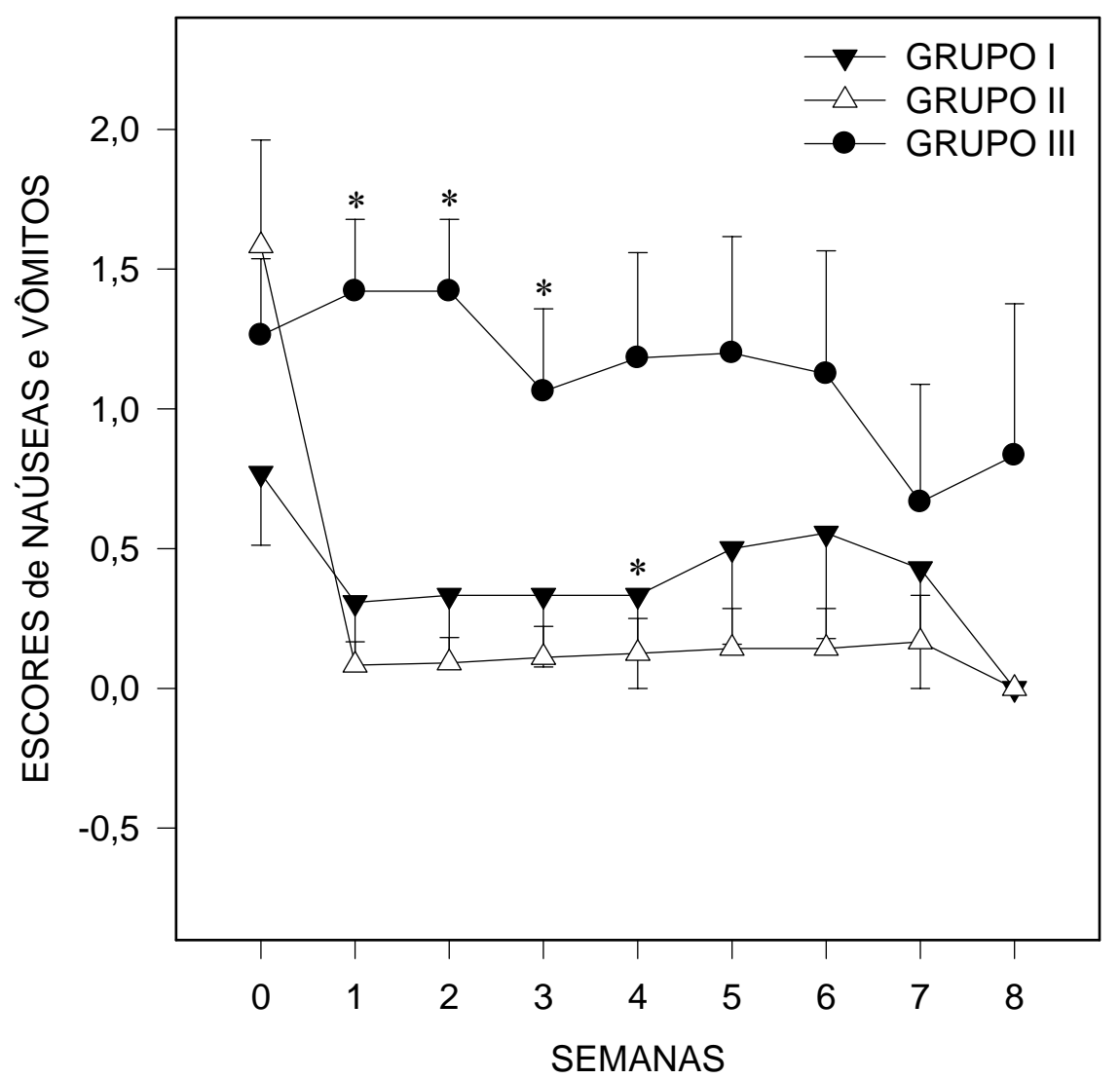

Figura 13- Média dos escores do sintoma náuseas e vômitos nos diferentes grupos ao longo das 8 semanas de observação. Os valores são de 0-3 (0= sem sintoma; 3= intolerável). Os grupos I (precoce) e II (tardio) foram submetidos a neurólise no tempo zero. O grupo III é o controle.

* diferente dos grupos I e II, $p<0,05$. 


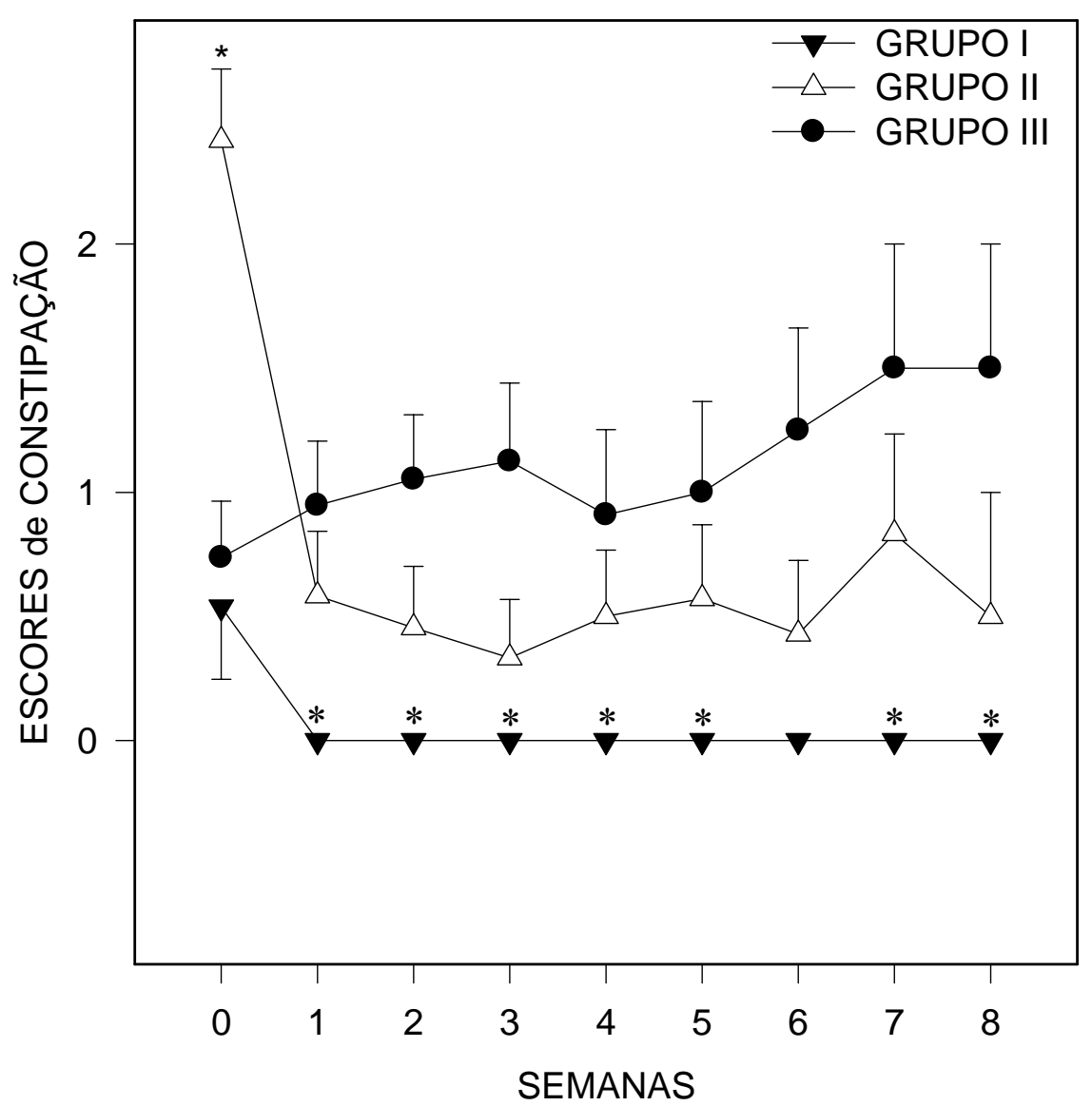

Figura 14- Média dos escores do sintoma constipação nos diferentes grupos ao longo do tempo de observação. ( $0=$ sem sintoma; $3=$ intolerável). Os grupos 1 (precoce) e II (tardio) foram submetidos a neurólise no tempo zero. O grupo III é o controle.

* diferente dos grupos I e II.

\# diferente do grupo III.

$p<0,05$. 


\section{DISCUSSÃO}

No presente trabalho observamos que a neurólise de plexos (celíaco, hipogástrico ou simpático) reduz a intensidade da dor (VAS) e o consumo de opióides em pacientes oncológicos, com dor abdominal ou pélvica, quando comparados com pacientes que fizeram uso somente de medicação analgésica. Também observamos melhor qualidade de vida e redução dos efeitos colaterais dos opióides nos pacientes submetidos às neurólises. Não observamos diferenças no VAS e no consumo de opióides, bem como na qualidade de vida e efeitos colaterais (exceto constipação) entre os grupos submetidos a neurólises precoce ou tardia. Os pacientes do grupo I (precoce) apresentaram incidência de constipação significativamente menor do que os do grupo II (tardio).

A interrupção de vias nociceptivas pela neurólise de plexos simpáticos têm sido propostas como alternativa no tratamento da dor oncológica. Lembrando-se que as fibras aferentes trafegam pelos nervos simpáticos. Trata-se de técnica eficaz que reduz de $70 \%$ a $90 \%$ a intensidade da dor, diminuindo a morbidade e melhorando a qualidade de vida destes pacientes (EISENBERG et al., 1995; DE LEON-CASASOLA, 2000, MERCADANTE et al., 2002). Existem poucos trabalhos aleatórios e controlados, como os de MERCADANTE (1993), LILLEMOE et al. (1993), KAWAMATA et al. (1996) e POLATI et al. (1998) e apenas três sugerem ser mais vantajosa a realização precoce da neurólise (ISCHIA et al., 1992; DE LEON CASASOLA et al., 1993b; LILLEMOE et al., 1993).

A escala analógica visual (VAS) é um método considerado eficaz para a mensuração da intensidade da dor (DE CONNO et al., 1994; PRICE et al., 
1994). Estas escalas são aceitas por diversas Sociedades, tais como "American Society of Anesthesiology"; "American Society of Regional Anesthesia"; "American Pain Society"; "Canadian Pain Society"; "Australian Pain Society": "European Pain Society" (ASRA, Annual Meeting, 1996), para avaliação de dor em humanos (VALLEY, 1996). Este método mostrou redução significativa da magnitude da intensidade da dor nos grupos submetidos a neurólise de plexos em relação ao grupo controle. Tais resultados estão em acordo com os obtidos por REID et al. (1970), THOMPSON et al. (1977), HANKEMEIER (1987), PLANCARTE et al. (1989), PRICE et al. (1989), PLANCARTE et al. (1990), ISCHIA et al. (1992), DE LEONCASASOLA et al. (1993a), LILLEMOE et al. (1993), EISENBERG et al. (1995), KAWAMATA et al. (1996), PATT et al. (1998), POLATI et al. (1998), DE LEONCASASOLA (2000), MIGUEL (2000), RYKOWSKI \& HILGIER (2000), DE CICCO et al. (2001), KONDO et al. (2001), VRANKEN et al. (2001), CARIATI et al. (2002), LEJCKO et al. (2002), MERCADANTE et al. (2002), YUEN et al. (2002) e SEHGAL (2003), que relatam diminuição da intensidade da dor crônica de origem maligna após bloqueio de plexos. Alguns destes trabalhos relatam os bloqueios em patologias específicas, como adenocarcinoma de pâncreas, mas podem ser extrapolados para outras doenças malignas abdominais e pélvicas, como colocam REID et al. (1970), THOMPSON et al. (1977), SINGLER (1982), HANKEMEIER (1987), PLANCARTE et al. (1989), PLANCARTE et al. (1990), HASTINGS \& MCKAY (1991), DE LEON-CASASOLA et al.(1993a), EISENBERG et al. (1995), MERCADANTE \& NICOSIA (1998), PATT et al. (1998), DE LEON-CASASOLA (2000), MIGUEL (2000), DE CICCO et al. (2001), CARIATI et al. (2002), LEJCKO et al. (2002), MERCADANTE et al. (2002) e SEHGAL (2003). Trabalhos como os de SINGLER (1982), BROWN (1989), HASTINGS \& McKAY (1991), WALDMAN et al. 
(1991), ROSENBERG et al. (1998) e GRESS et al. (1999) descrevem o sucesso de bloqueios de plexos e gânglios simpáticos na redução da intensidade da dor em pacientes com patologias tanto malignas quanto benignas.

Divergindo do nosso estudo, MERCADANTE (1993) não encontrou diferença entre o VAS do grupo de pacientes submetidos à neurólise do plexo celíaco e o do grupo de pacientes tratados farmacologicamente com analgésicos opióides. Nos pacientes tratados apenas com medicação analgésica, as doses foram aumentadas em $30 \%$ todas as vezes que o VAS foi superior a $4 \mathrm{~cm}$. Houve redução do VAS nos dois grupos estudados, contudo o consumo de analgésico opióide foi significativamente superior no grupo tratado somente com medicação analgésica. Para manter o VAS baixo, foi então preciso aumentar a dose de analgésico, o que também aumentou os efeitos colaterais decorrentes do uso de opióides (constipação, náuseas, sonolência, cansaço). Tal fato explica a redução do VAS após iniciar o tratamento com analgésicos em relação ao índice basal (sem medicação) como achado por MERCADANTE (1993). Em nosso estudo, os pacientes do grupo controle já estavam usando opióides na primeira semana (índice basal). Nas observações subseqüentes, o VAS manteve-se alto ou aumentou em relação aos grupos I e II, mostrando que os pacientes do grupo III não obtiveram analgesia adequada, embora tivessem sido reavaliados semanalmente e o esquema da medicação modificado conforme a necessidade de cada paciente. Nossos pacientes foram orientados a aumentar a dose conforme a necessidade ou caso apresentassem dor incidental. Tal fato nem sempre ocorreu porque os pacientes não compreenderam a orientação, não sabiam fazê-lo, ou não o fizeram devido aos efeitos colaterais. Devemos ressaltar que os dados foram obtidos de pacientes que buscaram a rede pública de atendimento médico. Em nosso meio, os pacientes são 
oriundos da população carente e, provavelmente, de baixo nível educacional. Análise destes dados não foram computadas por não ter ocorrido uma investigação detalhada de tal fato e suas implicações, cabendo aqui apenas citá-las.

Outro trabalho em que não se observou diferença no VAS foi realizado por VENTAFRIDDA et al. (1990), que também fixaram o valor do VAS e ofereceram doses progressivamente maiores de opióides a fim de alcançar a meta do VAS $<4$ nos pacientes em uso exclusivo de terapia farmacológica.

Em relação à duração do bloqueio, o VAS manteve-se significativamente baixo durante as oito semanas de observação. Boa analgesia ou alívio completo da dor foi encontrado em alguns pacientes submetidos à neurólise, além do tempo de observação de 8 semanas. Contudo, no grupo controle, alguns pacientes que foram acompanhados por tempo superior ao proposto, mantiveram dor de difícil controle. Na meta-análise realizada por EISENBERG et al. (1995), concluiu-se que, após a neurólise do plexo celíaco, os pacientes reportaram excelente alívio da dor durante as primeiras duas semanas e que, ao longo de três meses, ainda apresentaram benefícios da neurólise. Alívio completo e parcial da dor até 3 meses após a neurólise foi observado em $90 \%$ dos casos e, acima de três meses ou até a morte, 70 - 80\% relataram boa analgesia. Duração semelhante do efeito analgésico da neurólise foi encontrado por RYKOWSKI \& HILGIER (2000). Já POLATI et al. (1998) observaram que os pacientes apresentaram redução significativa da intensidade da dor imediatamente após o bloqueio quando comparados com os pacientes que receberam apenas medicação analgésica, contudo esta diferença não se manteve ao longo do tempo. A neurólise do plexo celíaco aboliu a dor, até a morte do paciente, em 10 - 24\% dos pacientes quando aplicada sozinha e em 80 - 90\% quando associada a outras formas de tratamento 
(ISCHIA et al., 1992). Redução no VAS durante 4 semanas subseqüentes à realização de bloqueios do plexo celíaco quando comparado com tratamento com morfina foi observado por KAWAMATA et al. (1996).

A ressecção cirúrgica, em bloco, da artéria, gânglios e do plexo celíaco no câncer de pâncreas avançado em 5 pacientes foi reportada por KONDO et al. (2001), com sucesso no alívio na dor por período de 8 a 15 meses. Porém, trata-se de relato com número pequeno de pacientes.

O consumo de analgésicos não opióides e opióides refletem a intensidade da dor e a quantidade de analgésicos necessária para o alívio da dor do paciente. É um método indireto de mensurar a dor e avaliar a eficiência da neurólise. Os nossos achados de diminuição do consumo de opióides pós neurólise estão de acordo com os resultados dos trabalhos realizados por THOMPSON et al. (1977), JONES \& GOUGH (1977), PLANCARTE et al. (1989), MERCADANTE (1993), DE LEON-CASASOLA et al. (1993a), DE LEON-CASASOLA et al. (1995), KAWAMATA et al. (1996), POLATI et al. (1998), RYKOWSKI \& HILGIER (2000), VRANKEN et al. (2001), CARIATI et al. (2002), LEJCKO et al. (2002) e MERCADANTE et al. (2002). Em nosso estudo, observamos consumo significativamente menor de opióides durante todo o tempo de observação (8 semanas) nos pacientes submetidos a neurólise, independentemente do procedimento ter sido realizado precoce ou tardiamente. Em alguns casos o efeito ultrapassou o tempo de observação, porém não nos coube realizar estatísticas nestes casos, mas apenas ressaltar tal fato.

SHARFMAN \& WALSH (1990) questionaram a efetividade do bloqueio do plexo celíaco em reduzir o consumo de opióides nos pacientes oncológicos. Em levantamento de 15 artigos realizados pelos autores até aquela data, não havia nenhum estudo prospectivo, aleatório ou controlado. Outro problema 
foi encontrar apenas 2 trabalhos com descrição do uso de opióides antes da neurólise. Não havia também especificação dos analgésicos utilizados e de suas dosagens, e em apenas um trabalho se relatou a intensidade da dor. A avaliação da qualidade da dor não fora descrita em nenhum dos estudos anotados. Posteriormente, outros trabalhos supriram a maioria destes questionamentos (EISENBERG et al., 1995; POLATI et al., 1998; DE LEON-CASASOLA, 2000).

Recentemente, VAN GEENEN et al. (2002) não observaram diminuição do consumo de analgésicos após neurólise do plexo celíaco quando comparado com a radioterapia. Trata-se, no entanto, de estudo retrospectivo, não aleatório ou controlado. Os pacientes dos três grupos de observação encontravamse em diferentes estágios evolutivos do tumor, sendo que o grupo submetido à neurólise estava em uma fase mais avançada da doença, marcada pela presença de metástases à distância, as quais não foram especificadas pelos autores e nem a importância delas no quadro álgico dos pacientes. Inicialmente, este grupo consumia analgésicos em quantidade significativamente maior do que os demais, mas sem diferença quanto ao uso de opióides, reforçando a importância de outros tipos e locais de dor (p.ex. metástases ósseas) além da abdominal. Outro questionamento se refere à comparação da sobrevida dos pacientes, já que se encontravam em estágios diferentes da doença.

A melhora na qualidade de vida total e nos fatores somáticos, psicossomáticos e físicos, mas não no fator social, foi demonstrado nos grupos submetidos à neurólise precoce e tardio, em relação ao grupo controle. Conseqüentemente, houve redução da morbidade nestes pacientes. VRANKEN et al. (2001) também encontraram aumento significativo na qualidade de vida (aspectos funcionais e físicos) após o tratamento. De acordo com KAWAMATA et al. (1996), a 
neurólise do plexo celíaco reduz significativamente a deterioração do estado clínico em relação aos pacientes tratados apenas farmacologicamente. Contudo, estes autores não obtiveram diferença na qualidade de vida entre os grupos além de duas semanas de observação, argumentando que tal avaliação utiliza índice subjetivo, influenciado por aspectos individuais dos pacientes como personalidade, características étnicas, culturais, religiosas e circunstanciais.

Aumento do tempo de sobrevida de pacientes oncológicos submetidos à neurólise foi constatada por LILLEMOE et al. (1993) e POLATI et al. (1998). Nosso tempo de observação foi fixado em 8 semanas, impossibilitando assim inferir sobre esta questão. No entanto, a experiência de nossa clínica é favorável às alusões feitas por LILLEMOE et al. (1993) e POLATI et al. (1998).

Qual o melhor momento para se realizar a neurólise ainda permanece em aberto. A OMS (WHO, 1996) aventa o tratamento mais conservador, com uso de largas doses de opióides e apenas em última instância propõe o uso de técnicas invasivas. ISCHIA et al. (1992), LILLEMOE et al. (1993), PATT et al. (1998) e ISCHIA et al. (1998) alvitraram que a neurólise precoce é mais efetiva do que em estágio avançado da doença, até prevenindo subseqüente início de dor. Nosso estudo não evidenciou diferenças entre a realização precoce e a tardia da neurólise que, entretanto, foram extraordinariamente superiores ao tratamento conservador. Vale lembrar que os bloqueios neurolíticos não previnem o avançar da doença e o envolvimento de estruturas extraviscerais, o que está sujeito a mudanças no mecanismo que mantém a dor (ORLANDINI, 1994; POLATI et al., 1998; MERCADANTE, 2002). Contudo, grandes benefícios são alcançados com a realização dos mesmos em prol do conforto do paciente oncológico. 
Alguns autores colocam a necessidade de repetir a neurólise em certos casos. DE LEON-CASASOLA (1993a) e LEJCKO et al. (2002) descreveram a necessidade em repetir a neurólise em 12\% dos pacientes em decorrência de analgesia incompleta após a primeira tentativa. LILLEMOE et al. (1993) colocam que em $12 \%$ dos pacientes só foi necessário nova neurólise onze meses após a primeira neurólise, achado favorável ao efeito duradouro do procedimento.

Os efeitos adversos mais comuns do uso crônico de opióides são constipação, náuseas e vômitos, sonolência, confusão mental, sedação e depressão respiratória (WHO, 1996). Em nosso estudo a incidência de efeitos colaterais de opióides foi maior nos pacientes que receberam somente medicação analgésica quando comparado com os que foram submetidos à neurólise. Os efeitos mais comumente encontrados foram: diminuição do apetite, constipação e náuseas e/ou vômitos, os quais foram significativamente maior no grupo controle. Mais raramente, observamos sonolência, tontura e retenção urinária. POLATI et al. (1998) relacionou aos analgésicos, os efeitos colaterais mais freqüentemente encontrados nos pacientes com terapia medicamentosa os quais foram: constipação, náuseas e/ou vômitos e sangramento digestivo por úlcera duodenal, este ultimo foi correlacionado ao uso de AINEs. Observaram estes efeitos em 100\% dos pacientes do grupo placebo e contra 41\% (constipação) e 33\% (náuseas e/ou vômitos) nos pacientes tratados com neurólise do plexo celíaco. THOMPSON et al. (1977) colocaram que o menor consumo de opióides acarretado pela neurólise permitiu diminuir a freqüência de náuseas, melhorou o apetite, aumentou o peso corporal e melhorou a função intestinal. Outro efeito relacionado ao uso de opióides foi a depressão do sistema imunológico, tanto em indivíduos sadios quanto em pacientes oncológicos (YEAGAR 
et al., 1995 e SACERDOTE et al., 2000). Entretanto este efeito não foi considerado em nosso estudo.

EISENBERG et al. (1995) considerou os bloqueios de plexos relativamente seguros e descreveu que os efeitos adversos mais comumente encontrados foram: hipotensão (38\%), diarréia (44\%) e dor local (96\%), todos transitórios e revertidos espontaneamente ou com tratamento. Nós observamos hipotensão (24\%) e diarréia (8\%) após a neurólise sem diferenças significativas entre os grupos estudados. Porém, houve uma tendência na queda da pressão arterial no grupo I, em relação ao grupo II, a qual pode ser explicada pelo número maior de neurólise do plexo celíaco neste grupo. Dos pacientes que sofreram neurólise, apenas 16\% pacientes necessitaram intervenção com vasopressor.

Não observamos nenhuma complicação grave devida à neurólise, o que está em concordância com os trabalhos de JONES \& GOUGH (1977), THOMPSON et al. (1977), MOORE et al. (1981), ISCHIA et al. (1992), MERCADANTE (1993), DE LEON-CASASOLA et al. (1995), EISENBERG et al. (1995), PLANCARTE et al. (1997), POLATI et al. (1998), VRANKEN et al. (2001) e YUEN et al. (2002). Todavia cabe relembrar os relatos de paraplegia e paralisia motora transitória descritos por LEUNG et al. (1983), BROWN (1989), HAYAKAWA et al. (1997) e ABDALLA \& SCHELL (1999). Outras complicações também descritas foram: pneumotórax (BROWN et al., 1987), punção vascular e infiltração de contraste no músculo psoas (PLANCARTE et al., 1989), obstrução venosa periférica por descolamento de placa de ateroma da artéria ilíaca e hematoma retroperitoneal (DE LEON-CASASOLA et al., 1993a) e isquemia aguda mielopática por envolvimento com artéria de Adamkiewicz (BROWN \& RORIE, 1994; MERCADANTE \& NICOSIA, 1998). Acreditamos que tais complicações das 
neurólises foram potencialmente reduzidas com o uso rotineiro de métodos de imagem para a localização dos plexos e gânglios.

A utilização de métodos de imagem para o correto posicionamento das agulhas antes do agente neurolítico ser empregado tem sido proposta. PATT et al. (1998) argumentam que com a utilização dos métodos de imagem, houve redução de complicações e a necessidade de se repetir o bloqueio. Para a abordagem, foram descritos inicialmente a fluoroscopia e posteriormente alguns autores propuseram a tomografia computadorizada (SINGLER, 1982; ISCHIA et al., 1992; RYKOWSKI \& HILGIER, 2000; CARIATI et al., 2002) e ultra-sonografia endoscópica (GRESS et al., 1999). Não obstante, o método mais utilizado é a fluoroscopia (HONET et al., 1993; EISENBERG et al., 1995) por apresentar baixo custo, tempo real da imagem durante a injeção de substâncias e verificação da correta localização das agulhas antes da injeção. Injeções intravascular, intraespinhal, intramuscular (psoas) ou ao longo do diafragma são facilmente reconhecidas (RAJ et al., 1996). Outra vantagem é a disponibilização deste método de imagem no centro cirúrgico. RIZZI et al. (1987) indicam o uso da tomografia computadorizada nos pacientes que apresentam alterações anatômicas devido ao crescimento do tumor no avançar da doença e pela facilidade de localizar tais estruturas. DE CICCO et al. (2001) apresenta a técnica pré-crural com uma agulha, onde emprega a tomografia computadorizada. A grande vantagem da tomografia computadorizada é a precisão da localização da agulha, útil quando há grandes variações anatômicas devido o avançar da doença. Porém, o seu alto custo e a demanda, restringi sua utilização (RAJ et al., 1996). CARIATI et al. (2002) serviu-se também da tomografia computadorizada no bloqueio de plexos hipogástricos. A utilização de ultra-sonografia endoscópica, como guia do bloqueio de plexo celíaco, 
têm a vantagem de mostrar imagens detalhadas das estruturas anatômicas incluindo estruturas vasculares, porém ainda pouco documentada (GRESS et al., 1999). Nós utilizamos a fluoroscopia para realizar as neurólises pelo baixo custo, experiência, destreza e prática com este método de imagem.

Outras técnicas de abordagem para interrupção das vias nociceptivas foram descritas. ISCHIA et al. (1992) comparam três abordagens diferentes para o plexo celíaco (trans-aórtica, retrocrural e esplenectomia bilateral). Não foi contemplado nenhuma diferença significativa nos resultados quanto ao efeito analgésico entre as técnicas utilizadas. Implante de cateter no plexo celíaco (VRANKEN et al., 2001) para posterior administração do agente neurolítico, p.ex. álcool, mostrou-se eficaz em reduzir o VAS, diminuir o consumo de opióides e aumentar a qualidade de vida durante 4 semanas. A possibilidade de uma nova neurólise quando o alívio da dor não é satisfatório, foi a grande vantagem oferecida por esta técnica. HUNG et al. (2002) propuseram uma nova abordagem para a neurólise do celíaco por meio da técnica transvertebral que mostrou maior facilidade do que as outras técnicas.

Bloqueio teste com anestésico local tem seu valor diagnóstico questionado para predizer a eficácia da neurólise ou determinar a proporção dos vários tipos de dores presentes (ISCHIA et al., 1992; YUEN et al., 2002). YUEN et al. (2002) discutem a legitimidade do bloqueio anestésico antes da neurólise pois, apesar de um valor preditivo positivo (85\%) e sensibilidade (93\%) altos, encontraram valor preditivo negativo (58\%) e especificidade (37\%) baixos. Em nosso estudo não utilizamos o bloqueio teste pelos motivos discutidos aqui.

O álcool absoluto foi o agente neurolítico utilizado para os bloqueios de plexo celíaco e hipogástrico assim como nos trabalhos de SINGLER (1982), 
VENTAFRIDDA et al. (1990); WALDMAN et al. (1991), ISCHIA et al. (1992), LILLEMOE et al. (1993), MERCADANTE (1993); EISENBERG et al. (1995), KAWAMATA et al. (1996), POLATI et al. (1998), RYKOWSKI \& HILGIER (2000), DE CICCO et al. (2001), CARIATI et al. (2002) e LEJCKO et al. (2002). Outros trabalhos empregaram o fenol por ser menos doloroso (PLANCARTE et al., 1990; HASTING \& McKAY, 1991; DE LEON-CASASOLA, 1993a; DE LEON-CASASOLA, 1995). A título de ressalva, no presente trabalho utilizamos o fenol apenas na neurólise do simpático lombar.

Sumarizando, o presente estudo mostrou a importância e eficácia das neurólises de plexos no tratamento da dor oncológica por reduzir significativamente a intensidade da dor e o consumo de drogas analgésicas. Por conseguinte, melhorou a qualidade de vida dos pacientes. A utilização precoce ou tardia desta abordagem não se mostrou diferente quando comparada entre elas, porém notavelmente superior ao tratamento conservador em reduzir a dor, o consumo de drogas e a ocorrência de efeitos colaterais. Todavia, para a realização destes procedimentos, faz-se necessário pessoal treinado, recursos técnicos e tecnológicos apropriados, além das condições clínicas do paciente. Sendo assim, este recurso deve ser disponibilizado aos pacientes oncológicos preferivelmente ao tratamento conservador quando possível e desejado, alvitrando sempre o melhor conforto do paciente. Tal fato, contradiz a OMS a qual preconiza a terapia medicamentosa em primeira instância. 


\section{CONCLUSÕES}

A abordagem da utilização da neurólise de plexos e gânglios simpáticos em pacientes oncológicos, através deste estudo, permitiu-nos inferir que:

1. É útil em abolir a dor oncológica abdominal e pélvica;

2. A neurólise é superior ao tratamento conservador;

3. O momento para realizar o procedimento (precoce ou tardio) não apresenta diferença.

A neurólise de plexos e gânglios simpáticos é útil em abolir a dor abdominal e pélvica em pacientes oncológicos, com raras complicações e efeitos adversos reversíveis e tratáveis, permitindo uma redução notável do consumo de drogas analgésicas e da ocorrência de efeitos colaterais destes medicamentos. Do mesmo modo que melhora a qualidade de vida do pacientes submetidos a eles.

A utilização precoce ou tardia desta abordagem não se mostrou diferente em reduzir a intensidade da dor ou a redução do consumo de opióides quando comparada entre elas, contudo significativamente superior ao tratamento farmacológico. Desse modo, este recurso deve ser utilizado preferivelmente ao tratamento conservador, porém qual o melhor momento a fazê-lo ainda é necessário novos trabalhos mais abrangentes no futuro. 


\section{REFERÊNCIAS BIBLIOGRÁFICAS}

Abdalla EK, Schell SR. Paraplegia following intraoperative celiac plexus injection. J Gastrointestinal Surg 1999;3(6):668-671.

Ahmedzai S. New approaches to pain control in patients with cancer. Eur J Cancer 1997;33(suppl. 6):S8-S14.

Ahmedzai S, Allan E, Fallon M, Finlay IG, Hanhs GW, Hanna M, Regnard CFB, Reilly C. Transdermal fentanyl in cancer pain. J Drug Dev 1994;6(3): 93-97.

American Academy of Pain Medicine, American Pain Society. Basic principles of ethics for the practice of pain medicine. Consensus Statement, 1999. Disponível em: URL: < http://www.painmed.org/productpub /statements/ > [2003 jun 14].

American Academy of Pain Medicine, American Pain Society, American Pain Society of Addiction Medicine. Definitions related to the use of opióides for the treatment of pain. Consensus Statement, 1997. Disponível em: URL:

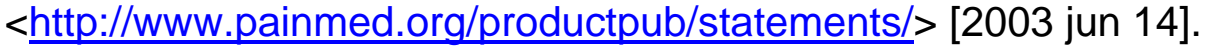

Ashburn MA and Staats PS. Management of chronic pain. The pain series. Lancet 1999;353(n.esp.),1865-1869.

Bernabei R, Gambassi G, Lapane K, Landi F, Gatsonis C, Dunlop R, Lipsitz L, Steel $\mathrm{K}$, Mor V. Management of pain in elderly patients with cancer. JAMA 1998;279(23):1877-1882.

Besson JM. The neurobiology of pain. The pain series. Lancet 1999;353(n.esp.):1610-1615.

Bonica JJ. The management of pain of malignant disease with nerve blocks. Anesthesiology 1954;15(n.esp.):280-301.

Brasil. Ministério da Saúde. Anuário estatístico de saúde do Brasil. MS, 2001. Disponível em: URL <http://portal.saude.gov.br/saude/aplicações /anuario 2001/mortal/introd.cfm> [2003 out 13]. 
Brown DL, Bulley CK, Quiel EL. Neurolytic celiac plexus block for pancreatic cancer pain. Anesth Analg 1987;66(n.esp.):869-873.

Brown DL. A retrospective analysis of neurolytic celiac plexus block for nonpancreatic intra-abdominal cancer pain. Reg Anesth 1989;14(2):63-65.

Brown DL, Rorie DK. Altered reactivity of isolated segmental lumbar arteries of dogs following exposure to ethanol and phenol. Pain 1994;56(n.esp.):139-143.

Caraceni A, Portenoy RK. Pain management in patients with pancreatic carcinoma. Cancer 1996; suppl. 78(3):639-653.

Caraceni A, Portenoy RK, a working group of the IASP Task Force on cancer pain. An international survey of cancer pain characteristics and syndromes. Pain 1999;82(n.esp.):263-274.

Cariati M, De Martini G, Pretolesi F, Roy MT. CT-guided superior hypogastric plexus block. J Computer Assisted Tomography 2002;26(3):428-431.

Cervero F, Laird JMA. Visceral pain. The pain series. Lancet 1999; 353(n.esp.):21452148.

Chapman CR, Gavrin J. Suffering: the contributions of persistent pain. The pain series. Lancet 1999;353(n.esp.):2233-2237.

Cherny NI, Portenoy R. Cancer pain: principles of assessment and syndromes. In: Wall PD, Melzack R. Textbook of pain. $4^{\mathrm{a} e d . ~ E d i n b u r g h: ~ C h u r c h i l l ~ L i v i n g s t o n e ; ~}$ 1999a. p. 1017-1064.

Cherny NI, Portenoy R. Practical issue in the management of cancer pain. In: Wall PD, Melzack R, ed. Textbook of pain. $4^{\mathrm{a} e d}$. Edinburgh: Churchill Livingstone; $1999 \mathrm{~b}$. p. 1479-1521.

Cleeland VS, Gonin R, Hatfield AK, Edmonson JH, Blum RH, Stewart JA, Pandya KJ. Pain and its treatment in outpatients with metastatic cancer. $N$ Engl $\mathrm{J}$ Med 1994;330(9):592-596.

Cohen MZ, Easley MK, Ellis C, Hughes B, Ownby K, Rashad BG, Rude M, Taft E, Westbrooks JB. Cancer pain management and the JCAHO's pain standards: an institutional challenge. J Pain Symptom Manage 2003;25(6): 519-527. 
Coluzzi PH, Schwartzberg L, Conroy JDJ, Charapata S, Gay M, Busch MA, Chavez, Asley J, Lebo D, McCracken M, Portenoy RK. Breakthrough cancer pain: a randomizado trial comparing oral transmucosa fentanyl citrate (OTFC $\AA$ ) and morphine sulfate immediate release (MSIR ${ }^{\circledR}$ ). Pain 2001;91(n.esp.):123-130.

De Cicco M, Matovic M, Bortolussi R, Coran F, Fantin D, Fabiani F, Caserta M, Santantonio C, Fracasso A. Celiac plexus block: injectate spread and pain relief in patients with regional anatomic distortions. Anesthesiology 2001; 94(n.esp.):561-565.

De Conno F, Caraceni A, Gamba A, Mariani L, Abbattista A, Brunelli C, La Mura, Ventafridda V. Pain measurement in cancer patients: a comparison of six methods. Pain 1994;57(n.esp.):161-166.

De Leon-Casasola OA, Kent E, Lema MJ. Neurolytic superior hypogastric plexus block for chronic pelvic pain associated with cancer. Pain 1993a;54(n.esp.):145-151.

De Leon-Casasola OA, Plancarte R, Patt RB, Lema MJ. Superior hypogastric plexus block using a single needle and computed tomography guidance. Reg Anesth 1993b;18(n.esp.):63. [Letter]

De Leon-Casasola OA, Plancarte R, Lema MJ. Neurolytic superior hypogastric plexus block for cancer pain: a multicenter experience with 159 patients. Anesthesiology 1995;83(3A):A843. [Abstracts]

De Leon-Casasola OA. Critical evaluation of chemical neurolysis of the sympathetic axis for cancer pain. Cancer Control 2000;7(2):142-148.

Ditonto ED and Leon-Casasola OA: Neurolytic Blockade for the Management of Pain associated with Cancer. In: Ashburn MA, Rice LJ. The Management of Pain. New York, Churchill Livingstone, 1998. p. 489-518.

Duthie AM, Ingham V. Persistent abdominal pain: treatment by lumbar sympathetic lysis. Anesthesiology 1981;36(n.esp.):289-292.

Eisenach JC, Du Pen S, Dubois M, Miguel R, Allin D et al. Epidural clonidine analgesia for intractable cancer pain. Pain 1995;61(n.esp.):391-399.

Eisenberg E, Berkey CS, Carr DB, Mosteller F, Chalmers TC. Efficacy and safety of nonsteroidal antiinflammatory drugs for cancer pain: a meta-analysis. J Clin Oncol 1994;12(12):2756-2765. 
Eisenberg E, Carr DB, Chalmers TC. Neurolytic Celiac Plexus block for Treatment of Cancer Pain: a meta-analysis. Anesth Analg 1995; 80(n.esp.):290-295.

Ferrer-Brechner T. Anesthetic techniques for the management of cancer pain. Cancer 1989;63(n.esp.):2343-2347.

Foley KM. The treatment of cancer pain. N Engl J Med 1985;313(2):84-95, July 11. [Editorial]

Gangliese L and Melzack R. Age-related differences in the qualities but not the intensity of chronic pain. Pain 2003;104(n.esp.):597-608. [Abstract]

Gordon DB. Morphine in cancer pain: multiple uses and misconceptions about addiction. Oncology issues 2003;18(4):41-42.

Gress F, Schmitt C, Sherman S, Ikenberry S, Lehman G. A prospective randomized comparison of endoscopic ultrasound- and computed tomography-guided celiac plexus block for managing chronic pancreatitis pain. Am $\mathrm{J}$ Gastroenterol 1999;94(4):900-905.

Grond S, Radbruch L, Meuser T, Sabatowski R, Loick G, Lehmann KA. Assessment and treatment of neuropathic cancer pain following $\mathrm{WHO}$ guidelines. Pain 1999;79(n.esp.):15-20.

Hankemeier U. Neurolytic celiac plexus block for cancer-related upper abdominal pain using the unilateral puncture technique and lateral position. Pain 1987;4(n.esp.):S135.

Hastings $\mathrm{RH}$, McKay WR. Treatment of benign chronic abdominal pain with neurolytic celiac plexus block. Anesthesiology 1991;75(n.esp.):156-158.

Hay RC: Subarachnoid alcohol block in the control of intractable pain: report of results in 252 patients. Anesth Analg 1962;41(n.esp.):12-16.

Hayakawa J, Kobayashi O, Murayama H. Paraplegia after intraoperative celiac plexus block. Anesth Analg 1997;84(n.esp.):447-448.

Holdcroft A, Power I. Management of pain: recent developments. BMJ 2003; 326(n.esp.):635-639. 
Honet JE, Shea KL, Seltzer JL. Celiac plexus neurolytic block: survey of pain programs. Anesthesiology 1993;79(3A):A833.

Hord $\mathrm{AH}$. The sympathetic nervous system. In: Parris, WCV. Cancer pain management: principles and practice. Boston: Butterworth-Heinemann; 1997. p. 99115.

Hung, C.J.; Tzeng, W.H.; Yip, W.H. A new approach to celiac plexus neurolysis: transvertebral technique. In: $10^{\circ}$ World Congress on Pain of IASP, San Diego, Aug 2002. Annals 587-P221. [Abstracts]

Hwang SS, Chang VT, Kasimis B. Cancer breakthrough pain characteristics and responses to treatment at a VA medical center. Pain 2003;101(n.esp.): 55-64.

Ischia S, Ischia A, Polati E, Finco G. Three posterior percutaneous celiac plexus block techniques. Anesthesiology 1992;76(4):534-540.

Ischia S, Polati E, Finco G, Gottin L, Benedini B. 1998 labat lecture: the role of the neurolytic celiac plexus block in pancreatic cancer pain management: do we have the answers? Reg Anesth Pain Med 1998;23(6):611-614.

Jacox A, Carr DB, Payne R. New clinical-practice guidelines for the management of pain patients with cancer. N Engl J Med 1994;330(9):651-655.

Jadad AR, Browman GP. The WHO analgesic ladder for cancer pain management: stepping up the quality of its evaluation. JAMA 1995;274(23): 1870-1873.

Johnson BW and Parris WCV. Mechanisms of cancer pain. In: Parris, WCV. Cancer pain management: principles and practice. Boston: Butterworth-Heinemann; 1997. p. 31-38.

Jones J, Gough D. Coeliac plexus block with alcohol for relief upper abdominal pain due to cancer. Ann R Coll Surg Engl 1977; 59(n.esp.):46-49.

Kappis M. Ertahrungen mit localanasthesia dês bauchuperationen. Verhandl der Deutsch Gesellsch I Chir 1914;87(n.esp.):43.

Kawamata M, Ishitani K, Ishikawa K, Sasaki H, Ota K, Omote K, Namiki A. Comparison between celiac plexus block and morphine treatment on quality of life in patients with pancreatic cancer pain. Pain 1996;64(n.esp.):597-602. 
Kimberly LP, Hailey BJo. Barriers to effective cancer pain management: a review of the literature. J Pain Symptom Mange 1999;18(5):358-368.

Kingery WS. A critical review of controlled clinical trials for peripheral neuropathic pain and complex regional pain syndromes. Pain 1997;73(n.esp.):123-139.

Kondo S, Katoh H, Omi M. Hirano S, Ambo Y, Tanaka E, Okushiba S, Morikawa, kanai M, Yano T. Radical distal pancreatectomy with en bloc resection of the celiac artery, plexus, and ganglions for advanced cancer of the pancreatic body: a preliminary report on perfect pain relief. J Pancreas 2001; 2(3):93-97.

Larue F, Colleau SM, Brasseur L, Cleeland CS. Multicentre study of cancer pain and its treatment in France. BMJ 1995;310(n.esp.):1034-1037.

Lebovits $\mathrm{AH}$ and Lefkowitz M. Pain management of pancreatic carcinoma: a review. Pain 1989;36(n.esp.):1-11.

Lejcko J, Machart S, Skalkova H, Bejvancicky S, Kasal E, Chytra I, Bilek M. The effect of plexus coeliacus neurolysis on severe cancer abdominal pain. In: $10^{\circ}$ World Congress on Pain of IASP; San Diego, 2002. San Diego: Annals, 2002. 585-P219. [Abstracts]

Lema JL, Adlaka R. The Assessment and Etiology of Pain in the Cancer Patient. In: Ashburn MA, Rice LJ. The Management of Pain. New York: Churchill Livingstone; 1998. p. 447-455.

Leung JWC, Bowen-Wright M, Aveling W, Shorvon PJ, Cotton PB. Coeliac plexus block for pain in pancreatic cancer and chronic pancreatitis. $\mathrm{Br} \mathrm{J}$ Surg 1983;70(n.esp.):730-732.

Levick S, Jarcobs C, Loukas DF, Gordon DH, Meyskens FL, Uhm K. Naproxen sodium in treatment of bone metastatic cancer. Pain 1988;35(n.esp.):253-258.

Levy MH. Pharmacologic treatment of cancer pain. N Engl J Med 1996;335 (15):1124-1132.

Lillemoe KD, Cameron JL, Kaufman HS, Yeo CJ, Pitt HA, Sauter PK. Chemical splanchnicectomy in patients with unresectable pancreatic cancer: a prospective randomized trial. Ann Surg 1993;217(5):447-457. 
Loeser JD, Melzack R. Pain: an overview. The pain series. Lancet 1999; 353(n.esp.):1607-1609.

Mandl F. Die paravertebral injection. Vienna, Springer-Verlag, 1926.

Makin MK, Ellershaw JE. Methadone can be used to manage neuropathic pain related to cancer. BMJ 1998;317(n.esp.):81. [Letter]

McQuay H. Opioids in pain management. The pain series. Lancet 1999;353(n.esp.), 2229-2232.

McQuay HJ, Tramèr M, Nye BA, Carroll D, Wiffen PJ, Moore RA. A Systematic review of antidepressants in neuropathic pain. Pain 1996;68(n.esp.):217-227.

Melzack R, Wall PD. Pain mechanisms: a new theory. Science Wash CD 1965;150(n.esp.):971-979.

Mercadante S. Celiac plexus block versus analgesics in pancreatic cancer pain. Pain 1993;52(n.esp.):187-192.

Mercadante S. Malignant bone pain: pathophysiology and treatment. Pain 1997;69(n.esp.):1-18.

Mercadante S and Nicosia F. Celiac plexus block: a reappraisal. Reg Anesth Pain Med 1998;23(1):37-48.

Mercadante S. Opioid rotation for cancer pain: rationale and clinical aspects. Cancer 1999;86(9):1856-1866.

Mercadante S, Fulfaro F, Casuccio A. Pain mechanisms involved and outcome in advanced cancer patients with possible indications for celiac plexus block and superior hypogastric plexus block. Tumori 2002;88(n.esp.):243-245.

Mercadante S, Catala E, Arcuri E, Casuccio A. Celiac plexus block for pancreatic cancer pain: factors influencing pain, symptoms and quality of life. J Pain Symptom Manage 2003;26(6):1140-1147.

Miguel R. Interventional treatment of cancer pain: the fourth step in the world health organization analgesic ladder? Cancer Control 2000;7(2):149-156. 
Moore DC. Regional block. $1^{\text {st }}$ ed. Springfield, IL: Charles C Thomas, 1965: 156-158, 332-333.

Moore DC, Bush WH, Burnett LL. Celiac plexus block: a roentgenographic, anatomic study of technique and spread of solution in patients and corpses. Anesth Analg 1981;60(6):369-379.

Moore DC. An improved technique for celiac plexus block may be more theoretical than real. Anesthesiology 1982;57(n.esp.):347-349.

Myers RR: The Pathogenesis of neuropathic pain. Regional Anesth 1995; 20(3):173184.

Oliveira AS, Sanchez CA. Plexo Celíaco. Rev Bras Anestesiol 1995a;45 (suppl.20):57-61.

Oliveira AS, Sanchez CA. Bloqueio do Plexo Hipogástrico Superior. Rev Bras Anestesiol 1995b;45(suppl.20):66-67.

Oliveira AS, Sanchez CA. Bloqueio Simpático lombar. Rev Bras Anestesiol 1995c;45(suppl.20):62-65.

Oliveira AS, Sanchez CA. Sistema Nervoso Autônomo e Síndromes Dolorosas. Rev. Bras. Anestesiol 1995d;45(suppl.20):43-52.

Orlandini, G. Selection of patients undergoing neurolytic superior hypogastric plexus block. Pain 1994;56(n.esp.):121. [Letter]

Payne R. Factors influencing quality of life cancer patients: the role of transdermal fentanyl in the management of pain. Sem Oncol 1998;25 (suppl.3):47-53.

Payne R, Mathias SD, Pasta DJ, Wanke LA, Williams R, Mahmoud R. Quality of life and cancer pain: satisfaction and side effects with transdermal fentanyl versus oral morphine. J Clin Oncol 1998;16(4):1588-1593.

Pargeon KL, Hailey BJ. Barriers to effective cancer pain management: a review of the literature. J Pain Symptom Manage 1999;18(5):358-368.

Patt RP, Millard R. A role for peripheral neurolysis in the management of intractable cancer pain. Pain 1990;5(suppl.):S358. 
Patt RB, Isaacson SA. Cancer pain syndromes. In: Raj, PP. Pain Medicine: a comprehensive review. St. Louis. Mosby; 1996. p. 502-520.

Patt RB, Reddy SK, Black RG. Neural blockade for abdominopelvic pain of oncologic origin. Int Anesth Clin 1998;3(3):87-104.

Pereira J, Lawlor P, Viganò A, Dorgan M, Bruera E. Equianalgesic dose ratios for opioids: a critical review and proposals for long-term dosing. J Pain Symptom Manage 2001;22(2):672-686.

Plancarte R, Amescua C, Patt RB, Aldrete A. Hypogastric plexus block: retroperitoneal approach. Anesthesiology 1989;71(3A):A739.

Plancarte R, Amescua C, Patt RB, Aldrete A. Superior hypogastric plexus block for pelvic cancer pain. Anesthesiology 1990;73:236-239.

Plancarte R, De Leon-Casasola OA, El-Helaly M, Allende S, Lema MJ. Neurolytic superior hypogastric plexus block for chronic pelvic pain associated with cancer. Reg Anesth Pain Med 1997;22:562-568.

Polati E, Finco G, Gottin L, Bassi C, Pederzoli P, Ischia S. Prospective randomized double-blind trial of neurolytic celiac plexus block in patients with pancreatic cancer. Br J Surg 1998;85(n.esp.):199-201.

Portenoy RK, Lesage P. Management of cancer pain. Lancet 1999; 353(n.esp.):1695-1700.

Prado WA. Medicamentos analgésicos de ação central. In: Fundamentos de psicofarmacologia. São Paulo: Atheneu; 1999. p. 175-195.

Price DD, Bennett GJ, Rafii A. Psychophysical observations on patients with neuropathic pain relieved by a sympathetic block. Pain 1989;36(n.esp.):273-288.

Price DD, Bush FM, Long S, Harkins SW. A comparison of pain measurement characteristics of mechanical visual analogue and simple numerical rating scale. Pain 1994;56(n.esp.):217-226.

Raab, D. Cross-cultural issues in the treatment of cancer pain. Oncology issues 2003;18(4):36-38. 
Raj PP. Pain mechanisms. In: Raj PP. Pain Medicine: a comprehensive review. St. Louis: Mosby; 1996a. p. 12-23.

Raj PP. Reflex Sympathetic Dystrophy. In: Raj PP. Pain Medicine: a comprehensive review. St. Louis: Mosby; 1996b. p. 466-481.

Raj PP, Rauck RI, Racz GB. Autonomic nerve blocks. In: Raj PP. Pain Medicine: a comprehensive review. St. Louis: Mosby; 1996. p. 227-255.

Reid W, Watt JK, Gray TG. Phenol injections of the sympathetic chain. Br J Surg 1970;57(1):45-50.

Regan JM, Peng P. Neurophysiology of cancer pain. Cancer Control 2000; 7(2):111119.

Rigor BM. Pelvic cancer pain. J Surg Oncol 2000;75(n.esp.):280-300.

Rizzi R, Biscuola G, Visentim M. Celiac plexus block. How anatomical alterations due to cancer growth can modify diffusion of contrast medium. Pain 1987;4(n.esp.):S135.

Robertson $\mathrm{DH}$. Transsacral neurolytic nerve block. An alternative approach to intractable perineal pain. Br J Anaesth 1983;55(n.esp.):873-875.

Rosenberg SK, Tewari R, Boswell MV, Thompson GA, Seftel AD. Superior hypogastric plexus block successfully treats severe penile pain after transurethral resection of the prostate. Reg Anesth Pain Med 1998;23(6): 618-620.

Rosenquist RW: Pharmacologic Management of Neuropathic Pain. In: $24^{\text {th }}$ Annual Meeting Workshops; ASRA 1999. p. 37-50.

Rykowski JJ and Hilgier M. Efficacy of neurolytic celiac plexus block in varying locations of pancreatic cancer: influence on pain relief. Anesthesiology 2000;92(n.esp.):347-354.

Sacerdote P, Bianchi M, Gaspani L, Manfredi B, Maucione A, Terno G, Ammatuna M. The effects of Tramadol and Morphine on immune responses and pain after surgery in cancer patients. Anesth Analg 2000;90(n.esp.): 1411-1414. 
Sarti CA. A dor, o indivíduo e a cultura. Saúde e Sociedade 2001;10(1) jan-jul.

Schaible H, Grubb BD. Afferent and spinal mechanisms of joint pain. Pain 1993;55:554.

Schroeder ME. Neurolytic nerve block for cancer pain. J Pain Symptom Manage $1986 ; 1(2): 91-94$.

Sehgal N. Neural blockade and cancer pain. Oncol issues 2003, 18: 39-40. Disponível em: URL: http//www.medscape.com.viewarticle/458966. [2003 ago 26].

Sharfman WH, Walsh TD. Has the analgesic efficacy of neurolytic celiac plexus block been demonstrated in pancreatic cancer pain? Pain 1990;41(n.esp.):267-271.

Shvartzman P, Friger M, Shani A, Barak F, Yoram C, Singer Y. Pain control in ambulatory cancer patients: can we do better? J Pain Symptom Manage 2003;26(2):716-722.

Siddall PJ and Cousins MJ. Introduction to pain mechanisms: implications for neural blockade. In: Cousins MJ, Bridenbaugh PO. Neural blockade: in clinical anesthesia and management of pain. $3^{\mathrm{a} e d .}$ Philadelphia: Lippincott-Raven; 1998. p. 675-713.

Singler RC. An improved technique for alcohol neurolysis of the celiac plexus. Anesth 1982;56(n.esp.):137-141.

Sittl R, Grossinger N, Likar R. Analgesic efficacy and tolerability of transdermal buprenorphine in patients with inadequately controlled chronic pain related to cancer and other disorders: a multicenter, randomized, double-blind, placebo-controlled trial. Clin Ther 2003;25(1):150-168. [Abstract]

Smitt PS, Tsafka A, De Zande FT, Van Holt R, Vries IE, Elfrink E, Van Bent MJ, Vecht CJ. Outcome and complications of epidural analgesia in patients with chronic cancer pain. Cancer 1998;83(9):2015-2022.

Stein C, Comisel K, Yassouridis A, Lehrberger K, Herz A, Peter K. Analgesic effect of intraarticular morphine after arthroscopic knee surgery. $N$ Engl $J$ Med 1991;325(16):1123-11126. [Abstract]

Stein C. The control of pain in peripheral tissue by opioids. $\mathrm{N}$ Engl $\mathrm{J}$ Med 1995;332(25):1685-1690. 
Tanelian DL, Cousins MJ. Failure of epidural opioid to control cancer pain in a patient previously treated with massive doses of intravenous opioid. Pain 1989;36(n.esp.):359-362.

Tegeder I, Meier S, Burian M, Schmidt H, Geisslinger G, Lötsch J. Peripheral opioid analgesia in experimental human pain models. Brain 2003;126(5): 1092-1102.

Thompson GE, Moore DC, Bridenbaugh LD, Artin RY. Abdominal pain and alcohol celiac plexus nerve block. Anesth Analg 1977;56(1):1-5.

Twycross RG. Opioids. In: Wall PD and Melzack R. Textbook of pain. $4^{\mathrm{a} e d .}$ Edinburgh: Churchill Livingstone; 1999. p.1187-1214.

Umeda S, Arai T, Hatano Y, Mori K, Hoshino K. Cadaver Anatomic Analysis of the Best Site for Chemical Lumbar Sympathectomy. Anesth Analg 1987; 66(n.esp.):643646.

Valley MA. Pain measurement. In: Raj PP. Pain Medicine: a comprehensive review. St. Louis: Mosby; 1996. p. 36-45.

Van Geenen RCI, Keyzer-Dekker CMG, Van Tienhoven G, Obertop H, Gouma DJ. Pain management of patients with unresectable peripancreatic carcinoma. World $\mathrm{J}$ Surg 2002;26(6):715-720.

Vranken JH, Zuurmond WWA, De Lange JJ. Increasing the efficacy of a celiac plexus block in patients with severe pancreatic cancer pain. J Pain Symptom Manage 2001;22(5):966-977.

Ventafridda $\mathrm{V}$. Continuing care: a major issue in cancer pain management. Pain 1989;36(n.esp.):137-143. [Editorial].

Ventafridda GV, Caraceni AT, Sbanotto AM, Barletta L, De Conno F. Pain treatment in cancer of the pancreas. Eur J Surg Oncol 1990;16(n.esp.):1-6.

Viganó A, Bruera E, Suarez-Almazor ME. Age, pain intensity, and opioid dose in patients with advanced cancer. Cancer 1998;83(6):1244-1250.

Waldman SD, Wilson WL, Kreps RD. Superior hypogastric plexus block using a single needle and computed tomography guidance: description of a modified technique. Reg Anesth 1991;16(n.esp.):286-287. 
Wolff SN. Epidemiology: the distribution and determination of adult cancer. In: Parris, WCV. Cancer pain management: principles and practice. Boston, ButterworthHeinemann, 1997. p. 25-30.

Woolf $\mathrm{CJ}$ and Decosterd I. Implications of recent advances in understanding of pain pathophysiology for the assessment of pain in patients. Pain 1999;6 (suppl.):S141S147.

Woolf CJ, Mannion RJ. Neuropathic pain: aetiology, symptoms, mechanisms, and management. The pain series. Lancet 1999;353:1959-1964.

World Health Organization. Cancer Pain Relief: with a guide to opioid availability. $2^{\mathrm{a} e d .}$ Geneva: World Health Organization; 1996. 70p.

Yang LC, Chen LM, Wang CJ, Buerkle H. Postoperative analgesia by intraarticular neostigmine in patients undergoing knee arthroscopy. Anesthesiology 1998;88(n.esp.):334-339.

Yeager MP, Colacchio TA, Yu TC, Hildebrandt L, Howell AL, Weiss J, Guyre PM. Morphine inhibits spontaneous and cytokine-enhanced natural killer cell cytotoxicity in volunteers. Anesthesiology 1995;83(3):500-508.

Yuen TST, Ng KFJ, Tsui SL. Neurolytic celiac plexus block for visceral abdominal malignancy: is prior diagnostic block warranted? Anesth Int Care 2002;30(n.esp.):442-448.

Zech DFJ, Grond S, Lynch J, Hertel D, Lehman KA. Validation of world health organization guidelines for cancer pain relief: a 10-year prospective study. Pain 1995;63(n.esp.):65-76. 
APÊNDICE 1 


\section{HOSPITAL DAS CLÍNICAS DA FACULDADE DE MEDICINA DE RIBEIRÃO PRETO DA UNIVERSIDADE DE SÃO PAULO}

Campus Universitário Monte Alegre -Fone: 633-1000

Cep 14048-900 Ribeirão Preto -São Paulo

TERMO DE CONSENTIMENTO PÓS-INFORMAÇÃO

NOME DA PESQUISA:

"Estudo comparativo dos efeitos da neurólise precoce ou tardia de plexos simpáticos no tratamento da dor oncológica abdominal e pélvica". PESQUISADOR RESPONSÁVEL:

Dra. RAQUEL DE OLIVEIRA CRM81082

Profa. Dra. MARLENE PAULINO REIS

INFORMAÇOES DADAS AOS PACIENTES:

1. A dor causada pela sua doença pode ter um componente relacionado à inervação e os medicamentos que você vem usando PODEM NÃO FAZER EFEITO. Vamos avaliar se esse NERVO é o que the trás maior desconforto e dor. Para isto serão realizadas, INJEÇÕES DE ANESTÉSICOS ou MEDICAÇÕES VIAS ORAIS, isto é, pela boca para aliviar sua dor.

2. As injeções de anestésicos são o que chamamos de bloqueios.O efeito destes bloqueios é destruir o nervo que causa a dor. Estes bloqueios são feitos há 15 anos na Clínica de Dor.

3. RISCOS:

- A pressão arterial pode cair um pouco. Mas você estará internado e sob os cuidados da equipe de enfermagem que fica o tempo todo medindo a pressão.

- O intestino vai ficar solto (diarréia) durante uma semana.

- Podem acontecer outros problemas que são raros e de possível tratamento, dependendo do local do bloqueio.

4. VANTAGENS: Você não vai precisar tomar grandes quantidades de remédios para tirar sua dor e nem medicações fortes que deixam você sonolento, incapacitado para suas atividades de rotina.

\section{PESQUISADOR RESPONSÁVEL}


Eu

R.G. $\mathbf{n}^{\circ}$ : , abaixo assinado, tendo recebido as informações acima, e ciente dos meus direitos abaixo relacionados, concordo em participar.

1 - A garantia de receber a resposta a qualquer pergunta ou esclarecimento a qualquer dúvida a cerca dos procedimentos, riscos, benefícios e outros relacionados com a pesquisa e o tratamento a que serei submetido;

2 - A liberdade de retirar meus consentimentos a qualquer momento e deixar de participar no estudo sem que isso traga prejuízo à continuação do meu cuidado e tratamento;

3 - A segurança de que não serei identificado e que será mantido o caráter confidencial da informação relacionada com a minha privacidade;

4 - O compromisso de me proporcionar informação atualizada durante o estudo, ainda que esta possa afetar minha vontade de continuar participando;

5 - A disponibilidade de tratamento médico e a indenização que legalmente teria direito, por parte da Instituição à saúde,em caso de danos que a justifiquem, diretamente causados pela pesquisa e ;

6 - Que se existirem gastos adicionais estes serão absorvidos pelo orçamento da pesquisa.

Tenho ciência do exposto acima e desejo utilizar o produto como método terapêutico recomendado pelo médico que subscreve este documento.

Ribeirão Preto, de de 
APÊNDICE 2 


\section{PROTOCOLO ESTUDO COMPARATIVO DOS EFEITOS DA NEURÓLISE PRECOCE OU TARDIA DE PLEXOS SIMPÁTICOS NO TRATAMENTO DA DOR ONCOLÓGICA ABDOMINAL E PÉLVICA}

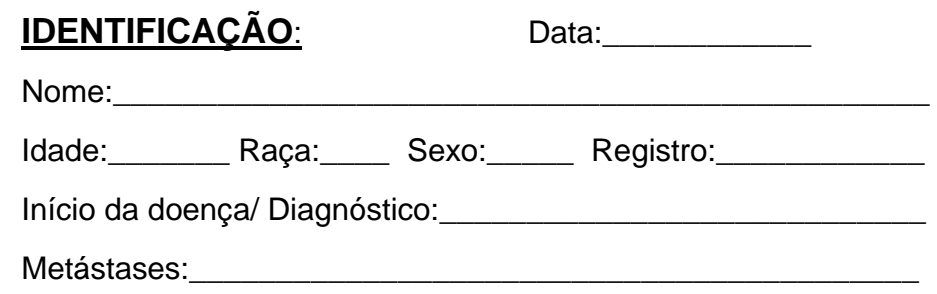

\section{AVALIAÇÃO DA DOR}

Localização da dor:

Duração da dor:

Qualidade da dor:

Irradiação:

Freqüência:

Intensidade: VAS =

CONSUMO DE ANALGÉSICOS NÃO OPIÁCEOS (Quantidade/dia) =

CONSUMO DE ANALGÉSICOS OPIÁCEOS (Quantidade/dia) =

CONSUMO DE COADJUVANTES (Quantidade/dia) =

\section{BLOQUEIO NEUROLÍTICO REALIZADO: DATA =}

Tipo:

Neurolítico usado: álcool

fenol
Uni ou bilateral:

Volume utilizado:

Concentração :

\section{AVALIAÇÕES SUBSEQUENTES DA DOR}

DATA:

TIPO DE DOR:

Localização da dor:

Duração da dor:

Qualidade da dor:

Irradiação:

Freqüência:

Intensidade: $\mathrm{VAS}$ depois do bloqueio $=$

CONSUMO DE ANALGÉSICOS NÃO OPIÁCEOS (Quantidade/dia) =

CONSUMO DE ANALGÉSICOS OPIÁCEOS (Quantidade/dia) =

CONSUMO DE COADJUVANTES (Quantidade/dia) = 


\section{QUESTIONÁRIO DE QUALIDADE DE VIDA}

DATA:

A- Avaliação de fatores múltiplos

1.Como está seu apetite?

1) Bom

2) Razoável

3) Ruim

4) Não come

2. Como está se sentindo?

1) Muito Bem

2) Bem

3) Ruim

4) Muito ruim

3. Está dormindo bem?

1) Muito Bem

2) Razoavelmente bem

3) Não muito bem

4) não estou dormindo

4. Quanto de dor está sentindo?

1) Nenhuma

2) Alguma, mas não é muito ruim

3) Muita, mas é tolerável

4) Muita e na maioria das vezes é intolerável

5. Você está tendo náuseas ou vômitos?

1) Não

2) Algum, mas não é ruim

3) Muito, mas eu posso tolerar isto

4) Muito e é intolerável

6. Você está tendo algum outro sintoma?

1) Não

2) Alguns, mas não incomodam

3) Sim, mas eu posso suportá-los

4) Sim e eles são intoleráveis

Obs: Nas respostas 2)-4) acima, descreva os sintomas 
7. Como está seu humor?

1) Muito Bom

2) Bom

3) Não muito bom

4) Muito ruim

8. Você tem disposição para assistir TV, ouvir rádio, ler,etc?

1) $\mathrm{Sim}$

2) Pouca

3) Quase nenhuma

4) Nenhuma

9. Você está satisfeito com seu relacionamento com seus médicos e enfermeiras?

1) Muito

2) $\mathrm{Sim}$

3) Não muito

4) Insatisfeito

10. Como é seu cotidiano?

1) Sou capaz de locomover sozinho

2) Eu necessito de alguma ajuda para locomover-se ou para coisas a minha volta

3) Eu freqüentemente necessito de ajuda para locomover-se ou para coisas a minha volta

4) Eu estou acamado e necessito de ajuda para tudo 
APÊNDICE 3 


\section{DADOS GERAIS DOS PACIENTES}

Tabela A1- Aspectos gerais dos pacientes do Grupo I.

\begin{tabular}{|c|c|c|c|c|c|c|c|}
\hline $\begin{array}{c}\text { GRUPO } \\
\text { I }\end{array}$ & RG & \multicolumn{2}{|c|}{$\begin{array}{r}\text { PAC. IDADE } \\
\text { (anos) }\end{array}$} & $\begin{array}{l}\text { T.OBS } \\
\text { (sem) }\end{array}$ & \multirow{2}{*}{$\begin{array}{l}\text { S SÍTIO } \\
\text { ) 1TUMOR } \\
\text { CA } \\
\text { hepático }\end{array}$} & \multirow{2}{*}{$\begin{array}{c}\text { METÁSTASES } \\
\text { óssea L4-L5 }\end{array}$} & \multirow{2}{*}{$\begin{array}{c}\text { BLOQUEIO } \\
\text { Celíaco }\end{array}$} \\
\hline caso1 & $442189 K$ & ADSG & 65 & 50 & & & \\
\hline caso3 & 488757J & BMRS & 49 & 3 & $\begin{array}{l}\text { CA colo } \\
\text { CA }\end{array}$ & invasão por contigüidade & Hipogástrico \\
\hline caso7 & 491344F & JJS & 53 & 5 & pâncreas & hepática & Celíaco \\
\hline caso11 & $437312 \mathrm{~A}$ & JLBG & 62 & 10 & $\begin{array}{l}\text { CA ceco } \\
\text { CA }\end{array}$ & hepática, ovário, peritônio & Hipogástrico \\
\hline caso12 & $314278 D$ & LFP & 70 & 11 & $\begin{array}{l}\text { pâncreas } \\
\text { CA }\end{array}$ & retroperitônio & Celíaco \\
\hline caso15 & 459511E & MCJP & 48 & 27 & hepático & carcinomatose peritoneal & Celíaco \\
\hline caso16 & $445835 I$ & NFZ & 77 & 9 & $\begin{array}{l}\text { CA gástrico } \\
\text { CA }\end{array}$ & hepática & Celíaco \\
\hline caso21 & $540638 \mathrm{~J}$ & EAA & 47 & 9 & pâncreas & Peri-hepáticos & Celíaco \\
\hline caso22 & $573837 \mathrm{C}$ & OJMF & 52 & 6 & $\begin{array}{l}\text { CA gástrico } \\
\text { CA vias }\end{array}$ & hepática & Celíaco \\
\hline caso24 & 552502B & $\mathrm{AO}$ & 71 & 3 & $\begin{array}{l}\text { biliares } \\
\text { CA }\end{array}$ & & Celíaco \\
\hline caso30 & $601798 \mathrm{~K}$ & ARMF & 62 & 10 & hepático & peritoneal & Celíaco \\
\hline caso31 & $227399 A$ & SRR & 46 & 10 & $\begin{array}{l}\text { CA colón } \\
\text { CA }\end{array}$ & hepática e óssea do quadril & Celiaco \\
\hline caso44 & $594777 \mathrm{~K}$ & ESOS & 53 & 12 & pâncreas & & Celíaco \\
\hline
\end{tabular}

RG (registro geral do paciente no HCFMRP); pac. (iniciais do nome do paciente); t.obs (tempo de observação em semanas); sítio primário do tumor. 
Tabela A2- Aspectos gerais dos pacientes do Grupo II.

\begin{tabular}{|c|c|c|c|c|c|c|c|}
\hline $\begin{array}{c}\text { GRUPO } \\
\text { II } \\
\end{array}$ & RG & PAC & $\begin{array}{l}\text { IDADE } \\
\text { (anos) } \\
\end{array}$ & $\begin{array}{l}\text { T.OBS } \\
\text { (sem) }\end{array}$ & $\begin{array}{c}\text { SÍTIO } \\
\text { 1TUMOR }^{\circ} \text { TUMO }\end{array}$ & METÁSTASES & BLOQUEIO \\
\hline caso18 & $415362 \mathrm{H}$ & NC & 69 & 31 & CA próstata & $\begin{array}{l}\text { Ósseas (lombar, } \\
\text { fêmur, ísquio, } \\
\text { tórax) }\end{array}$ & Hipogástrico \\
\hline caso19 & 5342231 & PL & 47 & 10 & CA colo & Retroperitoneal & Hipogástrico \\
\hline caso25 & 592937C & OTK & 56 & 3 & CA pâncreas & $\begin{array}{l}\text { Hepática } \\
\text { Pélvica e }\end{array}$ & Celíaco \\
\hline caso29 & $552795 \mathrm{H}$ & JBS & 67 & 3 & Neo vesical & pulmonar & Hipogástrico \\
\hline caso32 & $244956 \mathrm{~F}$ & $A A B$ & 63 & 22 & CA próstata & Óssea sacral & Hipogástrico \\
\hline caso33 & 479064F & AJF & 64 & 24 & CA reto & pulmonar & Hipogástrico \\
\hline caso34 & $582530 \mathrm{~J}$ & MAPH & 57 & 8 & $\begin{array}{l}\text { CA colo } \\
\text { CA }\end{array}$ & Pélvica & $\begin{array}{l}\text { Hipogástrico } \\
\text { Simpático }\end{array}$ \\
\hline caso35 & $491462 I$ & NAT & 69 & 7 & retroperitônio & & Lombar \\
\hline caso42 & 039456J & ICB & 51 & 34 & CA reto & Pélvica & Hipogástrico \\
\hline caso45 & $587697 \mathrm{~K}$ & NA & 45 & 3 & CA colo & Óssea & Hipogástrico \\
\hline caso52 & $639517 \mathrm{H}$ & BJS & 61 & 6 & CA pâncreas & Hepática & Celíaco \\
\hline caso53 & $594784 \mathrm{~K}$ & JRS & 44 & 2 & CA esôfago & & Celíaco \\
\hline
\end{tabular}

RG (registro do paciente no HCFMRP); pac. (iniciais do nome do paciente); t.obs (tempo de observação em semanas); sítio primário do tumor. 
Tabela A3- Aspectos gerais dos pacientes do Grupo III.

\begin{tabular}{|c|c|c|c|c|c|c|c|}
\hline $\begin{array}{c}\text { GRUPO } \\
\text { III } \\
\end{array}$ & RG & PAC. & $\begin{array}{l}\text { IDADE } \\
\text { (anos) } \\
\end{array}$ & $\begin{array}{l}\text { T.OBS } \\
\text { (sem) } \\
\end{array}$ & $\begin{array}{c}\text { SíTIO } \\
\text { 1TUMOR }^{\circ}\end{array}$ & METÁSTASES & $\begin{array}{l}\text { LOCAL } \\
\text { DA DOR } \\
\end{array}$ \\
\hline caso8 & $540643 A$ & JBON & 58 & 12 & CA colon & $\begin{array}{l}\text { Óssea lombar } \\
\text { Hepático e }\end{array}$ & $\begin{array}{l}\text { abdominal } \\
\text { e dorso }\end{array}$ \\
\hline caso9 & $5277706 \mathrm{E}$ & JPF & 69 & 6 & CA gástrico & $\begin{array}{l}\text { retroperitônio } \\
\text { Hepático, pulmonar e }\end{array}$ & abdominal \\
\hline caso13 & $119425 C$ & MLL & 44 & 3 & CA cólon & $\begin{array}{c}\text { pelve } \\
\text { Invasão por }\end{array}$ & pélvica \\
\hline caso14 & $132604 G$ & MAS & 33 & 2 & CA colo & contigüidade & pélvica \\
\hline caso17 & 0446994E & NS & 56 & 4 & Neo renal & Hepática e pulmonar & r abdominal \\
\hline caso23 & $351088 K$ & JAE & 78 & 3 & CA próstata & Óssea lombar & pélvica \\
\hline caso27 & $341657 C$ & JOS & 72 & 3 & CA $1^{\mathrm{a}}$ oculto & Hepático & abdominal \\
\hline caso28 & $213026 \mathrm{H}$ & $\mathrm{AHAH}$ & 67 & 26 & CA colon & $\begin{array}{l}\text { Hepatıca, pulmonar, } \\
\text { esplênica e } \\
\text { retroperitoneal }\end{array}$ & abdominal \\
\hline caso36 & $59024 \mathrm{H}$ & AGT & 71 & 22 & CA $1^{a}$ oculto & Adenoma sacral & pélvica \\
\hline caso37 & 631403D & JLS & 71 & 3 & CA pâncreas & Hepático & abdominal \\
\hline caso38 & $214605 \mathrm{H}$ & RLS & 55 & 12 & CA mama & $\begin{array}{l}\text { Hepatıco, cervical, } \\
\text { mandibular } \\
\text { Óssea, hepática e }\end{array}$ & abdominal \\
\hline caso39 & $535786 G$ & LG & 69 & 9 & CA $1^{\mathrm{a}}$ oculto & $\begin{array}{c}\text { pulmonar } \\
\text { Hepática pelve e }\end{array}$ & pélvica \\
\hline caso40 & 423738J & NMC & 44 & 4 & $\begin{array}{l}\text { CA colo } \\
\text { CA cabeça }\end{array}$ & retroperitônio & pélvica \\
\hline caso41 & 4743171 & JIF & 70 & 6 & pâncreas & $\begin{array}{c}\text { Hepático } \\
\text { Carcinomatose } \\
\text { peritoneal e meta }\end{array}$ & abdominal \\
\hline caso43 & 532087E & LRNM & 40 & 17 & CA cólon & $\begin{array}{c}\text { ovário } \\
\text { Carcinomatose }\end{array}$ & abdominal \\
\hline caso46 & 486679E & JFB & 34 & 8 & CA gástrico & $\begin{array}{c}\text { peritoneal } \\
\text { Hepático, esplênico e } \\
\text { carcinomatose }\end{array}$ & $e^{\text {abdominal }}$ \\
\hline caso48 & 400267E & MJAR & 48 & 12 & CA ovário & peritoneal & abdominal \\
\hline caso49 & $140366 \mathrm{~J}$ & RSA & 35 & 6 & Neo renal & $\begin{array}{c}\text { Cervical } \\
\text { Retroperitônio, }\end{array}$ & abdominal \\
\hline caso51 & $017965 \mathrm{~J}$ & EDC & 48 & 3 & Neo gástrico & mediastino e cervical & I abdominal \\
\hline
\end{tabular}

RG (registro do paciente no HCFMRP); pac. (iniciais do nome do paciente); t.obs (tempo de observação); sítio primário do tumor e localização principal da dor. 
Tabela A4- Comportamento das pressões arteriais e da freqüência cardíaca dos pacientes do Grupo I antes (inicial) e após (final) a neurólise do plexo simpáticos.

\begin{tabular}{lcccccc}
\hline GRUPO I & PASi & PASf & PADi & PADf & FCi & FCf \\
\hline caso1 & 160 & 122 & 80 & 78 & 90 & 84 \\
caso3 & 90 & 114 & 60 & 62 & 92 & 107 \\
caso7 & 100 & 75 & 70 & 50 & 90 & 92 \\
caso11 & 100 & 90 & 70 & 60 & 92 & 60 \\
caso12 & 180 & 146 & 110 & 78 & 120 & 84 \\
caso15 & 110 & 80 & 60 & 50 & 100 & 108 \\
caso16 & 160 & 110 & 80 & 70 & 85 & 70 \\
caso21 & 140 & 117 & 90 & 83 & 100 & 105 \\
caso22 & 110 & 92 & 60 & 55 & 70 & 90 \\
caso24 & 120 & 64 & 80 & 45 & 80 & 70 \\
caso30 & 100 & 87 & 80 & 43 & 78 & 83 \\
caso31 & 102 & 100 & 77 & 57 & 102 & 100 \\
caso44 & 100 & 80 & 60 & 60 & 80 & 79 \\
\hline MÉDIA & 121 & 98,23 & 75,2 & 59,46 & 91 & 87,1 \\
\hline
\end{tabular}

PASi e PASf = pressão arterial sistólica inicial e final; PADi e PADf = pressão arterial diastólica inicial e final; FCi e FCf = freqüência cardíaca inicial e final, respectivamente. Dados expressos em valores absolutos. 
Tabela A5- Comportamento das pressões arteriais e da freqüência cardíaca dos pacientes do Grupo I I antes (inicial) e após (final) a neurólise do plexo simpáticos.

\begin{tabular}{lcccccc}
\hline GRUPO II & PASi & PASf & PADi & PADf & FCi & FCf \\
\hline caso18 & 88 & 139 & 80 & 68 & 100 & 106 \\
caso19 & 150 & 170 & 90 & 120 & 90 & 98 \\
caso25 & 140 & 78 & 90 & 57 & 110 & 124 \\
caso29 & 100 & 110 & 80 & 90 & 80 & 100 \\
caso32 & 160 & 165 & 90 & 92 & 100 & 63 \\
caso33 & 150 & 142 & 90 & 86 & 76 & 79 \\
caso34 & 150 & 112 & 90 & 72 & 100 & 79 \\
caso35 & 120 & 125 & 70 & 75 & 90 & 75 \\
caso42 & 140 & 130 & 80 & 67 & 90 & 88 \\
caso45 & 120 & 97 & 80 & 39 & 100 & 125 \\
caso52 & 120 & 126 & 100 & 84 & 80 & 68 \\
caso53 & 110 & 100 & 60 & 60 & 100 & 86 \\
\hline Média & 131 & 124,5 & 83,3 & 75,83 & 93 & 90,9 \\
\hline
\end{tabular}

PASi e PASf = pressão arterial sistólica inicial e final; PADi e PADf = pressão arterial diastólica inicial e final; FCi e FCf = freqüência cardíaca inicial e final, respectivamente. 
Tabela A6- Relação dos pacientes que tiveram tempo inferior a 8 semanas de observação conforme os critérios de saída do estudo distribuídos nos grupos experimentais.

\begin{tabular}{lccc}
\hline \multicolumn{1}{c}{ TEMPO DE OBSERVAÇÃO $<8$ SEMANAS } & & & \\
\hline \hline Óbito & GI & GII & GIII \\
Perdeu retorno & 3 & 6 & 8 \\
Mudou medicação e/ou via de administração & 2 & 0 & 2 \\
\hline
\end{tabular}

